\title{
PRISCILLA MORETHSON
}

MODUlaÇÃO DO TRANSPORTE DE PRÓTONS EM OSTEOClastos:

EFEITOS DA ACIDOSE E DO FLUXO DE FLUIDO EXTRACELULAR

Tese apresentada ao Programa de PósGraduação em Fisiologia do Instituto de Ciências Biomédicas da Universidade de São Paulo, para obtenção do título de Doutor em Ciências.

São Paulo 
PRISCILLA MORETHSON

MODULAÇÃO DO TRANSPORTE DE PRÓTONS EM OSTEOCLASTOS: EFEITOS DA ACIDOSE E DO FLUXO DE FLUIDO EXTRACELULAR

Tese apresentada ao Programa de PósGraduação em Fisiologia do Instituto de Ciências Biomédicas da Universidade de São Paulo, para obtenção do Título de Doutor em Ciências.

Área de concentração: Fisiologia Humana

Orientadora: Raif Musa Aziz

Versão original.

São Paulo 
DADOS DE CATALOGAÇÃO NA PUBLICAÇÃO (CIP)

Serviço de Biblioteca e Informação Biomédica do

Instituto de Ciências Biomédicas da Universidade de São Paulo

reprodução não autorizada pelo autor

Morethson, Priscilla.

Modulação do transporte de prótons em osteoclastos. Efeitos da acidose e do fluxo de fluido extracelular / Priscilla Morethson. -- São Paulo, 2011.

Orientador: Raif Musa Aziz.

Tese (Doutorado) - Universidade de São Paulo. Instituto de Ciências Biomédicas. Departamento de Fisiologia e Biofísica. Área de concentração: Fisiologia Humana. Linha de pesquisa: Fisiologia óssea, biologia celular de osteoclastos.

Versão do título para o inglês: Modulation of proton transport in osteoclasts. Effects of acidosis and extracellular fluid flow.

Descritores: 1. Reabsorção óssea 2. Osteoclastos 3. Secreção de $\mathrm{H}^{+}$4. Equilíbrio ácido-base 5. Regulação de $\mathrm{pH}$ intracelular I. MusaAziz, Raif II. Universidade de São Paulo. Instituto de Ciências Biomédicas. Programa de Pós-Graduação em Fisiologia Humana III. Título. 


\section{UNIVERSIDADE DE SÃO PAULO \\ INSTITUTO DE CIÊNCIAS BIOMÉDICAS}

Candidato(a): $\quad$ Priscilla Morethson.

Título da Tese: $\quad$ Modulação do transporte de prótons em osteoclastos. Efeitos da acidose e do fluxo de fluido extracelular.

Orientador(a): $\quad$ Raif Musa Aziz.

A Comissão Julgadora dos trabalhos de Defesa da Tese de Doutorado, em sessão

pública realizada a considerou

\section{( ) Aprovado(a) ( ) Reprovado(a)}

Examinador(a): Nome completo:

Instituição:

Examinador(a): Nome completo:

Instituição:

Examinador(a): Nome completo:

Instituição:

Examinador(a): Nome completo:

Instituição:

Presidente: Nome completo:

Instituição: 


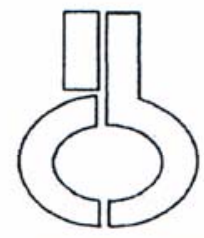

\section{UNIVERSIDADE DE SÃO PAULO INSTITUTO DE CIÊNCIAS BIOMÉDICAS}

\section{Certificado}

Certificamos que o protocolo registrado sob $\mathrm{n}^{\circ} 090$ nas fls. 35 do livro 2 para uso de animais em experimentação, sob a responsabilidade de Margarida de Mello Aires, Coordenador(a) da Linha de pesquisa "Ação do alendronato na regulação do pH e cálcio citosólicos de osteoclastos e na instalação e progressão da periodontite" do qual participou(aram) o(s) alunos Priscilla Morethson, está de acordo com os Principios Éticos de Experimentação Animal adotado pelo Colégio Brasileiro de Experimentação Animal (COBEA) e foi aprovado pela COMISSĀO DE ÉTICA EM EXPERIMENTAÇÃO ANIMAL (CEEA) em 19.09.2006.

São Paulo, 20 de setembro de 2006.



Prof. Dr. UbiRatan FABRES MACHADO Coordenador da CEEA - ICB/USP
Sāo Paul

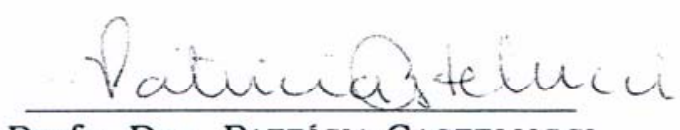

Profa. Dra. PATRÍCIA CASTELUCCI

Secretária da CEEA - ICB/USP 


\begin{tabular}{|l|l|}
\hline UNIVERSIDADE DE SÃO PAULO \\
INSTITUTO DE CIENCIAS BIOMÉDICAS \\
Cidade Universitária "Armando de Salles Oliveira" \\
Av. Prof. Lineu Prestes, 2415 - Cep. 05508-900 São Paulo, SP - Brasil \\
Telefone:(55) (011) 3091.7733 - telefax : (55) (011)3091-7438 \\
e-mail: cep@icb.usp.br \\
COMISSÃO DE ÉTICA NO USO DE ANIMAIS
\end{tabular}

Decl. CEUA. 081/2010

\section{E C L A R A Ç $\tilde{A} O$}

Em adendo ao Certificado 090/06, aprovado em 19.09.06, informo que por solicitação da Profa. Dra. Margarida de Mello Aires, a coordenação do protocolo: "Ação do alendronato na regulação do pH e cálcio citosólicos de osteoclastos e na instalação e progressão da periodontite" será de responsabilidade da Profa. Dra. RaIf MuSA Azız.

São Paulo, 20 de dezembro de 2010.



Prof. Dr. Wothan TAVARES DE Lima

Coordenador da CEUA

ICB/USP 
Dedico este trabalho a todos os interessados em Regulação de pH Intracelular, Fisiologia do Tecido Ósseo e Homeostase Ácido-Base. 
"A mente que se abre a uma nova ideia jamais voltará ao seu tamanho original." Albert Einstein 


\section{RESUMO}

Morethson P. Modulação do Transporte de Prótons em Osteoclastos. Efeitos da Acidose e do Fluxo de Fluido Extracelular [Tese de Doutorado]. São Paulo: Instituto de Ciências Biomédicas da Universidade de São Paulo; 2011.

A acidose metabólica causa perda de mineral ósseo e a estimulação mecânica causa remodelamento ósseo adaptativo. A reabsorção óssea que caracteriza essas mudanças ósseas depende da acidificação extracelular pela secreção vetorial de $\mathrm{H}^{+}$pelos osteoclastos. A $\mathrm{H}^{+}$-ATPase vacuolar em paralelo com o trocador $\mathrm{Cl}^{-} / \mathrm{H}^{+}$(CLC7) são os mecanismos conhecidos envolvidos na reabsorção óssea, entretanto, os osteoclastos também expressam canais para $\mathrm{H}^{+}$dependentes a voltagem. Este trabalho foi realizado para avaliar a contribuição dos canais para $\mathrm{H}^{+}$na função celular visando à compreensão de seu relacionamento com a $\mathrm{H}^{+}$-ATPase vacuolar e o CLC7 (1); analisar se o fluxo de fluido extracelular modifica a secreção de $\mathrm{H}^{+}$(2) e avaliar a diferenciação dos osteoclastos in vitro sob acidose metabólica devido à redução do $\mathrm{HCO}_{3}^{-}$(3). Osteoclastos de ratos Wistar foram obtidos diretamente dos animais ou foram diferenciados in vitro (com M-CSF e RANKL) e semeados sobre vidro, plástico ou substratos mineralizados em $\alpha$-MEM $+10 \%$ SFB, em pH 7,4 ou 6,9, e então mantidos em incubadora com $5 \% \mathrm{CO}_{2}$, a $37^{\circ} \mathrm{C}$. A diferenciação celular foi avaliada pela contagem de células TRAP-positivas ou de núcleos marcados por DAPI. A secreção de $\mathrm{H}^{+}$foi avaliada por epifluorescência, utilizando-se BCECF-AM, sensível a pH. Os registros do $\mathrm{pH}$ intracelular foram feitos na vigência de soluções tamponadas por HEPES, na ausência de $\mathrm{CO}_{2} / \mathrm{HCO}_{3}{ }^{-}\left(\mathrm{pH} 7,4,300 \mathrm{mOsm} / \mathrm{L} \mathrm{H}_{2} \mathrm{O}\right.$, a $\left.37^{\circ} \mathrm{C}\right)$, na presença ou ausência de perfusão contínua de fluido extracelular a uma velocidade de $5 \mathrm{ml} / \mathrm{min}$. $\mathrm{Na}$ ausência de perfusão, os osteoclastos exibiram variações cíclicas do pHi (acidificação e alcalinização espontâneas), com período de 12 a 45 minutos $(\mathrm{n}=35)$ e amplitude de 0,12 a 1,43 unidades de pHi. As oscilações não foram abolidas por concanamicina $(100 \mathrm{mM})(\mathrm{n}=3)$, por NPPB $(100 \mu \mathrm{M})(\mathrm{n}=3)$, na ausência de $\mathrm{Na}^{+}$ extracelular $(\mathrm{n}=5)$ ou na ausência de $\mathrm{Cl}^{-}$extracelular $(\mathrm{n}=3)$. O fluxo de fluido aboliu as oscilações e a ausência de $\mathrm{Cl}^{-}$extracelular modificou significativamente seu padrão. $\mathrm{Na}$ ausência de perfusão, a secreção de $\mathrm{H}^{+}$após acidificação intracelular induzida foi abolida por $\mathrm{Zn}^{2+}(100 \mu \mathrm{M})(\mathrm{n}=5)$. Além disso, na presença de perfusão, a secreção de $\mathrm{H}^{+}$após acidificação intracelular induzida foi abolida por NPPB $(n=4)$ e não foi 
abolida por bafilomicina $(200 \mathrm{~nm})(\mathrm{n}=3)$. A acidose metabólica não modifica o número de osteoclastos diferenciados in vitro, entretanto, o tratamento das culturas com $\mathrm{Zn}^{2+}$ causou redução do numero de células mononucleares e aumento relativo do número de osteoclastos multinucleados em relação ao controle tanto em pH 7,4 quanto em pH 6,9. Nossos dados mostram que a secreção de $\mathrm{H}^{+}$em osteoclastos ocorre por $\mathrm{ClC} 7$ e por canais para $\mathrm{H}^{+}$dependentes de voltagem e não depende da $\mathrm{H}^{+} \mathrm{ATPase}(1)$, que a secreção de $\mathrm{H}^{+}$é estimulada pela interrupção da perfusão de fluido extracelular (2) e que a acidose metabólica não favorece a diferenciação de osteoclastos, mas o $\mathrm{Zn}^{2+}$ tem efeito modulador da diferenciação (3).

Palavras-chave: Reabsorção Óssea. Osteoclastos. Secreção de $\mathrm{H}^{+}$. Equilíbrio ÁcidoBase. Regulação de pH Intracelular. 


\begin{abstract}
Morethson P. Modulation of Proton Transport in Osteoclasts. Effects of Acidosis and Extracellular Fluid Flow [PhD Thesis]. Sao Paulo: Instituto de Ciências Biomédicas da Universidade de São Paulo; 2011.
\end{abstract}

Metabolic acidosis can cause a loss of bone mineral and the mechanic stimulation can cause adaptative bone remodeling. The bone resorption characteristic of these bone changes aforementioned depends on the extracellular acidification by osteoclastmediated proton secretion. The $\mathrm{H}^{+}$secretion by vacuolar $\mathrm{H}^{+}$-ATPase together with $\mathrm{Cl}^{-}$ secretion through a $\mathrm{Cl}^{-} / \mathrm{H}^{+}$exchanger (CLC7) are the known mechanisms involved in the bone resorption; however, osteoclasts also express voltage-gated proton channels. The proposed aims of these work were to evaluate the contribution of proton channels in the osteoclast function for better understanding its relation with vacuolar $\mathrm{H}^{+}$-ATPase and CLC7 (1); to analyze whether the flow of extracellular fluid modifies the $\mathrm{H}^{+}$ secretion or not (2); and to analyse the osteoclast differentiation in vitro under metabolic acidosis due to $\mathrm{HCO}_{3}{ }^{-}$reduction (3). Osteoclasts were freshly isolated or generated from bone marrow precursor cells (using M-CSF and RANK- L) from of Wistar rats. The cells were placed on glass coverslips, plastic coverslips, or on mineralized substrate in $\alpha$-MEM $+10 \%$ FBS, pH 7.4 or 6.9 , and then maintained in a $5 \% \mathrm{CO}_{2}$ incubator at $37^{\circ} \mathrm{C}$. The differentiation was analyzed by counting of TRAP-stained cells or DAPIstained nuclei. The $\mathrm{H}^{+}$secretion was analysed by epifluorescence, using the $\mathrm{pH}$ sensitive dye BCECF-AM. The intracellular $\mathrm{pH}$ record was done using a standard HEPES-buffered solution free of $\mathrm{CO}_{2} / \mathrm{HCO}_{3}{ }^{-}\left(\mathrm{pH} \mathrm{7.4,} 300 \mathrm{mOsm} / \mathrm{L} \mathrm{H} \mathrm{H}_{2} \mathrm{O}\right.$, at $37{ }^{\circ} \mathrm{C}$ ), with or without continuous perfusion of extracellular fluid at a rate of $5 \mathrm{ml} / \mathrm{min}$. In the absence of perfusion, the osteoclasts exhibit cyclic pHi variations (spontaneous acidification and alkalinization), with a period of 12 to 45 minutes $(n=35)$ and amplitude — difference between maximal and minimal $\mathrm{pHi}$ - of 0.12 to 1.43 units $\mathrm{pHi}$. These oscillations were not abolished in the presence of concanamycin $(100 \mathrm{mM})$ $(\mathrm{n}=3), \operatorname{NPPB}(100 \mu \mathrm{M})(\mathrm{n}=3)$, in the absence of $\mathrm{Na}^{+}(\mathrm{n}=5)$ or in the absence of $\mathrm{Cl}^{-}$ $(n=3)$ in the extracellular solution. The fluid flow itself abolished the $\mathrm{pH}$ oscillations 
and the absence of extracellular $\mathrm{Cl}^{-}$modifies significantly these patterns. In the absence of perfusion, the $\mathrm{H}^{+}$secretion after induced intracellular acidification was abolished by $\mathrm{Zn}^{2+}(100 \mu \mathrm{M})(\mathrm{n}=5)$. In addition, in the presence of perfusion, the $\mathrm{H}^{+}$secretion after induced intracellular acidification was abolished by NPPB $(n=4)$ and was not abolished by bafilomycin $(200 \mathrm{~nm})(\mathrm{n}=3)$. Metabolic acidosis does not modify the number of osteoclasts differentiated in vitro, however, when the cell culture was treated with $\mathrm{Zn}^{2+}$, there was a significant reduction in the number of mononuclear cells and a relative increase in the number of multinucleated osteoclasts compared to control, both in $\mathrm{pH} 7.4$ and $\mathrm{pH} 6.9$ medium. Our data show that the proton secretion in osteoclasts depends on CLC7 and voltage-gated proton channels and does not depend on $\mathrm{H}^{+}$ATPase activity (1), the proton secretion is stimulated with the interruption of extracellular fluid flow (2), metabolic acidosis does not improve the osteoclast differentiation but $\mathrm{Zn}^{2+}$ has a modulatory effect (3).

Key words: Bone Resorption. Osteoclasts. $\mathrm{H}^{+}$Secretion. Acid-base Homeostasis. Intracellular $\mathrm{pH}$ Regulation. 
SUMÁRIO

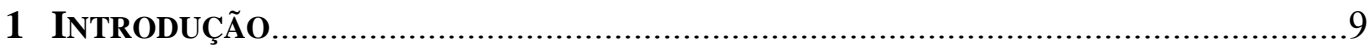

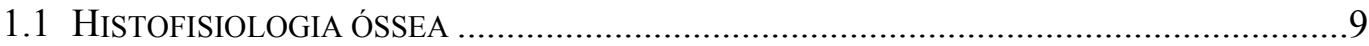

1.2 CONSTITUIÇÃO QUÍMICA DA MATRIZ MINERALIZADA E MODIFICAÇÕES ÓSSEAS INDUZIDAS PELA ACIDOSE................................................11

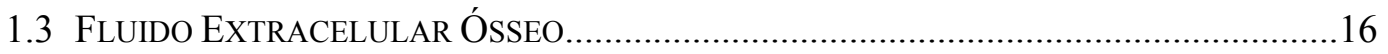

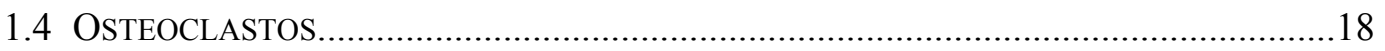

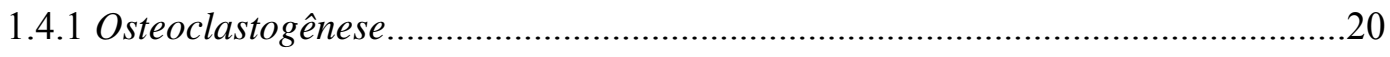

1.4.2 Biologia Celular do Osteoclasto - Secreção Ácida................................................22

1.4.3 Proteínas transportadoras de $\mathrm{H}^{+}$no osteoclasto.................................................23

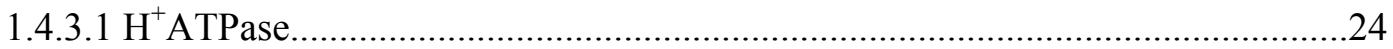

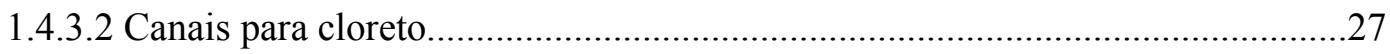

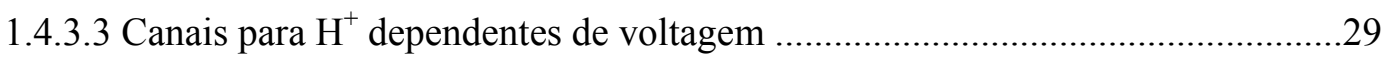

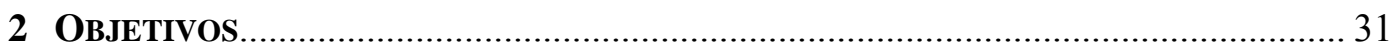

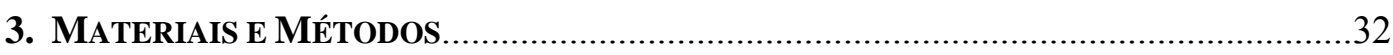

3.1 ISOLAMENTO E CULTIVO DE OSTEOCLASTOS DIFERENCIADOS IN VIVO.........................32

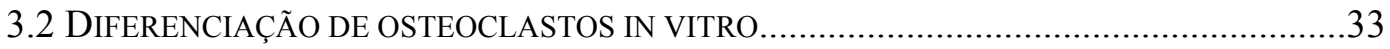

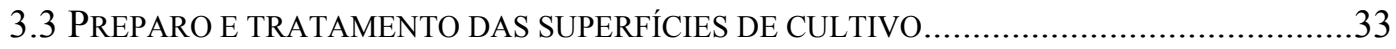

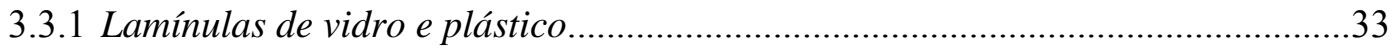

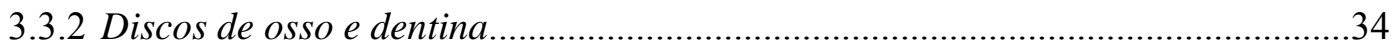

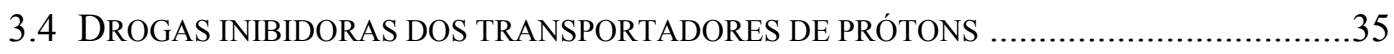

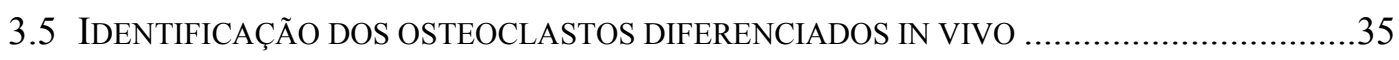

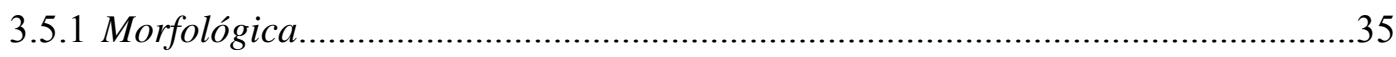

3.5.2 Imunofluorescência para o receptor de calcitonina (CTR)..................................36

3.6 CARACTERIZAÇÃO E QUANTIFICAÇÃO DOS OSTEOCLASTOS

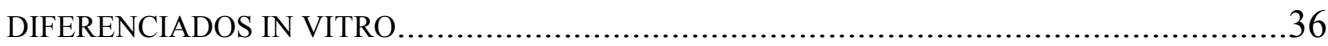

3.6.1 Citoquímica para fosfatase ácida resistente a tartarato (TRAP).........................36

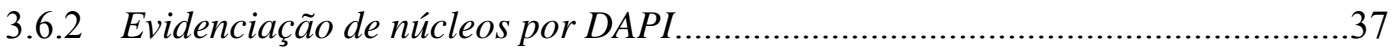

3.6.3 Imunolocalização de canais para $\mathrm{H}^{+}$dependentes de voltagem..........................38

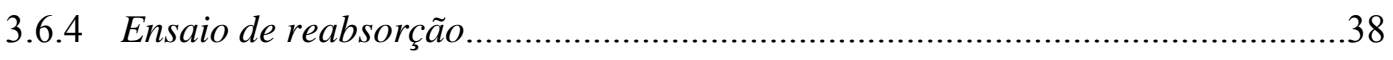

3.6.5 Eletroforese de proteínas, detecção de CLC7 e do canal para $H^{+}$ dependente de voltagem por anticorpos............................................................39 
3.7 MEDIDAS DE PHI POR FLUORESCÊNCIA DE BCECF



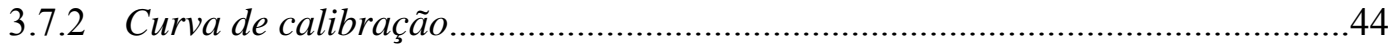

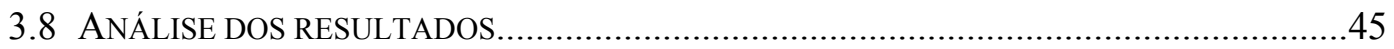

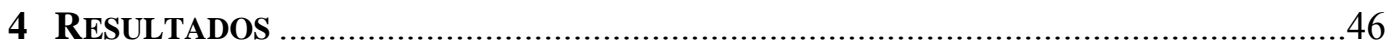

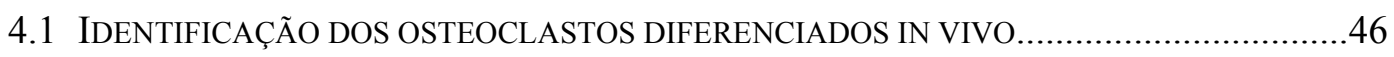

4.2 CARACTERIZAÇÃO DOS OSTEOCLASTOS DIFERENCIADOS IN VITRO..............................46

4.3 SECREÇÃO DE $\mathrm{H}^{+}$E REGUlaÇÃo de PHi DE OSTEOCLASTOS - EFEITOS DA ACIDIFICAÇÃO INTRACELULAR INDUZIDA E DO FLUXO DE FLUIDO EXTRACELULAR...50

4.4 DIFERENCIAÇÃO DE PRECURSORES EM OSTEOCLASTOS EM ACIDOSE METABÓLICA...64

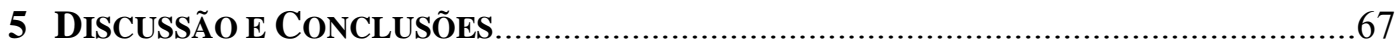

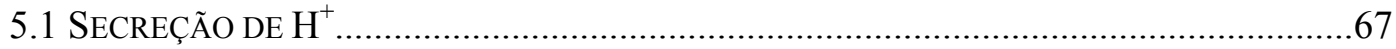

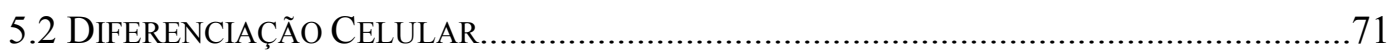

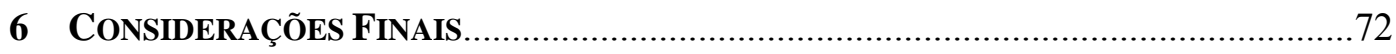

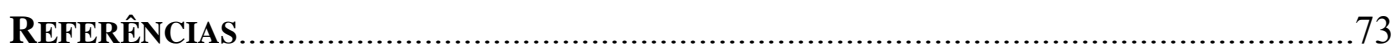




\section{INTRODUÇÃo}

\subsection{Histofisiologia ÓSSEA}

O osso é constituído por uma matriz extracelular, composta por mineral, colágeno, água, proteínas não-colágenas e lipídios, em ordem decrescente de proporção (Robey, Boske, 2008), e por uma pequena população de células. Macroscopicamente, o osso pode ser classificado como trabecular ou cortical: o osso trabecular fornece suporte à medula óssea e resistência às extremidades de ossos que sustentam peso, e o osso cortical está presente nas regiões externas e forma a estrutura cilíndrica dos ossos longos. Microscopicamente, o tecido ósseo organiza-se nos Sistemas de Havers, os quais são constituídos por camadas de tecido contendo componentes mineralizados e não-mineralizados, relacionadas estruturalmente a um canal vascular central, de onde provém o suprimento sanguíneo do tecido (Figura 1).

Figura 1 - Organização do osso cortical em Sistemas de Havers. Os pequenos pontos pretos vistos na imagem são os espaços que contém osteócitos. (Fêmur bovino, corado por azul de toluidina a $0,1 \%$. Aumento: 10 X.)

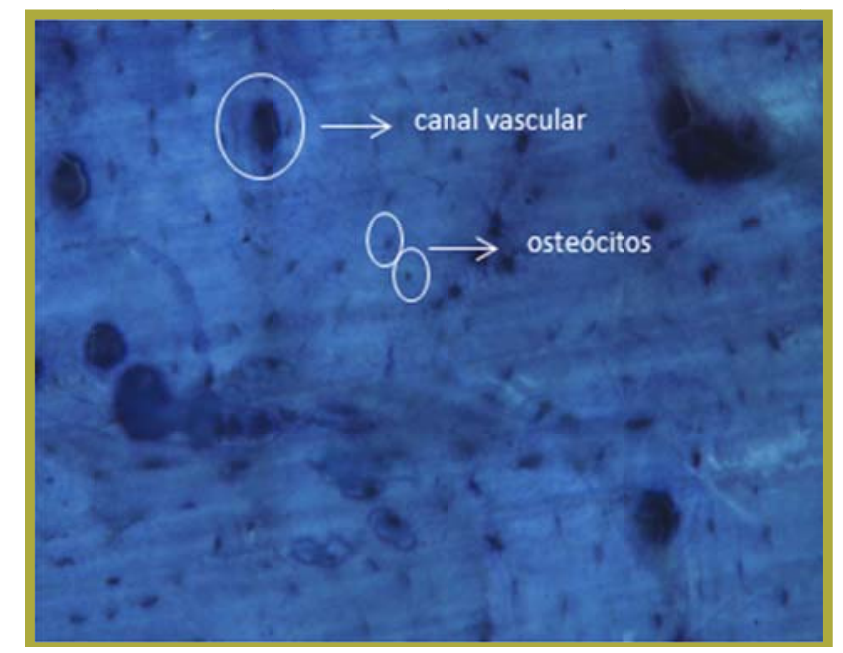

FONTE: Acervo pessoal.

A pequena população celular óssea é constituída por 1) osteoclastos, células que reabsorvem osso, 2) osteoblastos, células que formam osso, 3) osteócitos, que auxiliam na manutenção óssea, e 4) células de revestimento, que recobrem toda a superfície óssea. Os osteoblastos e células de revestimento correspondem a cerca de $4-6 \%$ das células do tecido 
ósseo, os osteócitos correspondem a 90-95\%, e os osteoclastos, a aproximadamente 1-2\% (Bonewald, 2008).

As células precursoras de osteoblastos são provenientes da medula óssea e podem diferenciar-se em osteoblastos ou em células adiposas, de modo que o controle da rota de diferenciação está sujeito à ação de diversos fatores. Os osteoblastos estão localizados nas superfícies ósseas em contato próximo com o suprimento vascular. Apresentam formato cuboidal e colunar, núcleo central, "gap junctions" e receptores para hormônios, tais como 1,25-dihidroxivitamina D3 (vitamina D3), estrógeno e paratormônio (PTH) (Cowin, 2007). Os osteoblastos sintetizam componentes orgânicos da matriz óssea extracelular, como o colágeno e outras proteínas não-colágenas e, após cumprida sua função, têm três destinos: 1) podem tornar-se osteócitos; 2) podem tornar-se células de revestimento ou 3) podem sofrer apoptose. Adicionalmente, participam da mineralização da matriz orgânica e controlam a reabsorção óssea por meio da síntese de RANKL ("receptor activator of nuclear factor kappa $\beta$-ligand”), que favorece a diferenciação e a atividade dos osteoclastos (Bonewald, 2008).

Os osteócitos são células com atividade sintética menor que a dos osteoblastos (Caetano-Lopes et al., 2007), são circundados por matriz mineralizada, e estão contidos dentro de lacunas, comunicando-se uns com os outros e com o ambiente por meio de prolongamentos. Cada osteócito apresenta muitos prolongamentos citoplasmáticos, estimamse 60 prolongamentos, de modo que cada célula estabelece contato nas três dimensões com outras 12 células, aproximadamente. Os prolongamentos celulares têm comprimento médio de $15 \mu \mathrm{m}$ e estão posicionados centralmente em "túneis" denominados canalículos (Cowin, 2007) (Figura 2).

Figura 2 - Os osteócitos e seus prolongamentos interconectados.

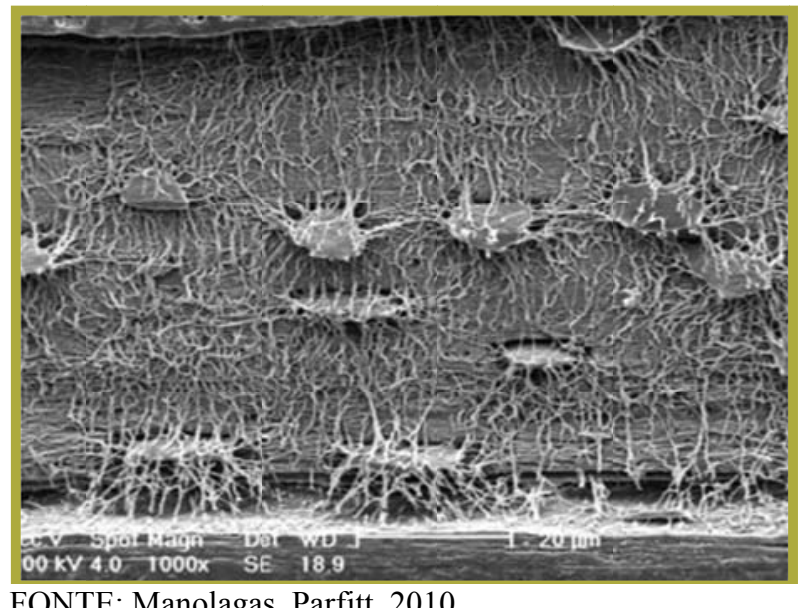

FONTE: Manolagas, Parfitt, 2010. 
Além das conexões existentes entre osteócitos, estes também se comunicam com outros tipos celulares, como os osteoblastos e as células de revestimento nas superfícies ósseas, e com a medula óssea. Assim, todas as células presentes no osso são extensivamente interconectadas pelos processos celulares dos osteócitos, formando uma rede celular de conexão (CCN - do inglês "connected cellular network") (Bonewald, 2008).

Apesar da aparência sólida, o tecido ósseo é continuamente remodelado para promover crescimento ou permitir que o tecido se reestruture em resposta a estímulos mecânicos e hormonais. Frente às solicitações mecânicas, o osso sofre modificações, o que constitui importante característica adaptativa óssea. Acredita-se que a recepção do estímulo mecânico ocorra no osteócito e que a rede CCN transduza o sinal, ou seja, transforme o sinal mecânico em sinal de outra natureza (por exemplo, sinal químico), e o transmita para os osteoblastos nas superfícies ósseas. Os osteoblastos então iniciam a formação de osso e regulam indiretamente a reabsorção óssea pelos osteoclastos, orquestrando assim o remodelamento ósseo (Cowin, 2007). Os efeitos diretos dos estímulos mecânicos sobre a função dos osteoclastos não são conhecidos.

\subsection{CONSTITUIÇÃO QUÍMICA DA MATRIZ MINERALIZADA E MODIFICAÇÕES ÓSSEAS INDUZIDAS PELA ACIDOSE}

Os ossos constituem importante reservatório mineral, contendo $99 \%$ do cálcio $\left(\mathrm{Ca}^{2+}\right)$, $35 \%$ do sódio $\left(\mathrm{Na}^{+}\right), 80 \%$ do carbonato $\left(\mathrm{CO}_{3}{ }^{2-}\right), 80 \%$ do citrato $\left(\mathrm{C}_{6} \mathrm{H}_{5} \mathrm{O}_{7}{ }^{3-}\right)$ e $60 \%$ do magnésio $\left(\mathrm{Mg}^{2+}\right)$ do organismo (Green e Kleeman, 1991). Adicionalmente, $80 \%$ do $\mathrm{CO}_{2}$ (dióxido de carbono) do organismo está presente nos ossos, sob a forma de $\mathrm{CO}_{3}{ }^{2-}, \mathrm{HCO}_{3}{ }^{-}$ (bicarbonato) e $\mathrm{CO}_{2}$ (Pasquale et al., 1980).

O mineral ósseo é um cristal altamente análogo à hidroxiapatita de ocorrência natural, cuja fórmula química é $\mathrm{Ca}_{10}\left(\mathrm{PO}_{4}\right)_{6}(\mathrm{OH})_{2}$, com estrutura nanocristalina, organizada num padrão tridimesional hexagonal-dipiramidal (Figura 3).

Frequentemente, no lugar de $\mathrm{Ca}^{2+}, \mathrm{PO}_{4}{ }^{3-}$ (fosfato) e $\mathrm{OH}^{-}$(hidroxila), outros átomos, moléculas ou íons podem constituir o mineral ósseo, como $\mathrm{CO}_{3}{ }^{2-}$, flúor, magnésio e fosfato ácido $\left(\mathrm{HPO}_{4}{ }^{2-}\right)$, constituindo, desse modo, estruturas moleculares diversas, como "brushite" $\left(\mathrm{CaHPO}_{4}\right)$, possivelmente precursora da apatita, a hidroxiapatita carbonatada e a flúorhidroxiapatita (Robey, Boske, 2008). Segundo Green e Kleeman (1991), chumbo, manganês, 
magnésio sódico e estrôncio substituem o cálcio; carbonato substitui o fosfato ou a hidroxila. A substituição de elementos ocorre primordialmente nas superfícies ósseas e depende das condições ambientais e da dieta (Robey, Boske, 2008).

Figura 3 - Estrutura cristalina das apatitas biológicas, cuja fórmula química é $\mathrm{Ca}_{10}\left(\mathrm{PO}_{4}\right)_{6}(\mathrm{OH})_{2}$.

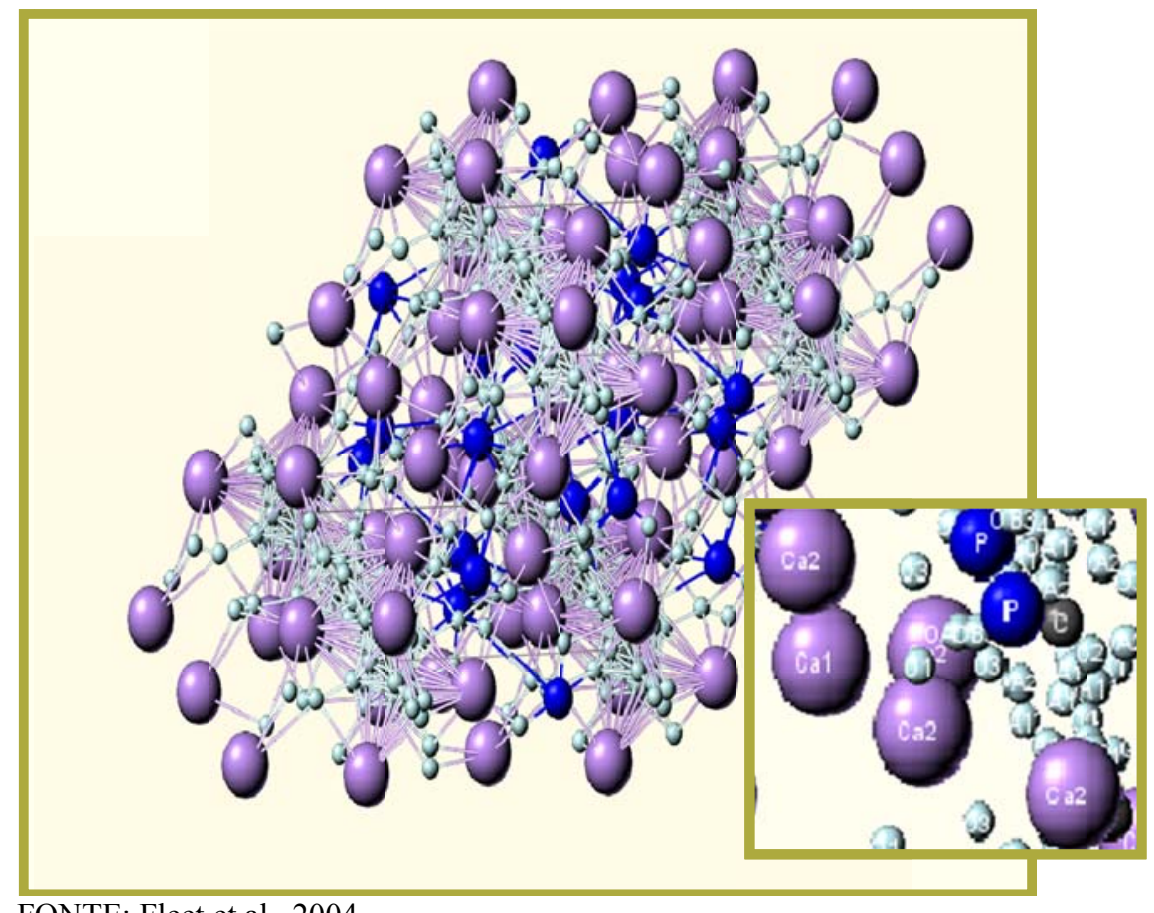

FONTE: Fleet et al., 2004.

Devido à complicada unidade estrutural dos cristais de hidroxiapatita $\left(10 \mathrm{Ca}^{2+}, 2 \mathrm{OH}^{-}\right.$, $\left.6 \mathrm{PO}_{4}{ }^{3-}\right)$, diferentes terminações de superfície com grande exposição de íons $\mathrm{Ca}^{2+}$ ou $\mathrm{PO}_{4}{ }^{3-}$ têm sido postuladas e, de acordo com o íon presente, são consideradas carregadas positivamente ou negativamente (Green, Kleeman, 1991) (Figura 4). Kwon et al. (2009) observaram in vitro e sob condições experimentais bem definidas que na faixa de $\mathrm{pH}$ de 6 até 11,6 existe exclusivamente a terminação do cristal em $\mathrm{PO}_{4}{ }^{3-}$. Os autores sugerem que a carga de superfície da hidroxiapatita não é determinada pela superfície dominante de $\mathrm{Ca}^{2+}$ ou $\mathrm{PO}_{4}{ }^{3-}$ mas pelo grau de protonação da terminação superficial específica (Figura 5).

A protonação de superfície promove a quebra das ligações entre átomos de $\mathrm{Ca}^{2+} \mathrm{e}$ oxigênio $\left(\mathrm{O}_{2}\right)$ e, por isso, a taxa de dissolução da hidroxiapatita aumenta à medida que o pH é reduzido, o que é um fenômeno geral observado na dissolução de outros minerais (Kwon et al., 2009). A modulação da dissolução da hidroxiapatita por pH ácido é fundamental para a reabsorção óssea e o metabolismo mineral, de modo que quando há redução do cálcio plasmático, por exemplo, a dissolução da hidroxiapatita óssea e a regulação da calcemia 
ocorrem por meio da diferenciação e atividade dos osteoclastos, células com capacidade de acidificação extracelular vetorial.

Figura 4 - A. Representação do cristal de hidroxiapatita em suspensão aquosa. B. Diagrama esquemático da camada de hidratação do cristal de hidroxiapatita. Segundo este modelo, a camada de hidratação é composta principalmente por íons cálcio $\left(\mathrm{Ca}^{2+}\right)$ polarizados hidratados e por íons fosfato $\left(\mathrm{PO}_{4}^{-3}\right)$ polarizados. Este arranjo reduziria a assimetria de cargas na interface cristal-água.


FONTE: Green, Kleeman, 1991.

Figura 5 - Representação esquemática da protonação de superfície do cristal de apatita em diferentes pHs.

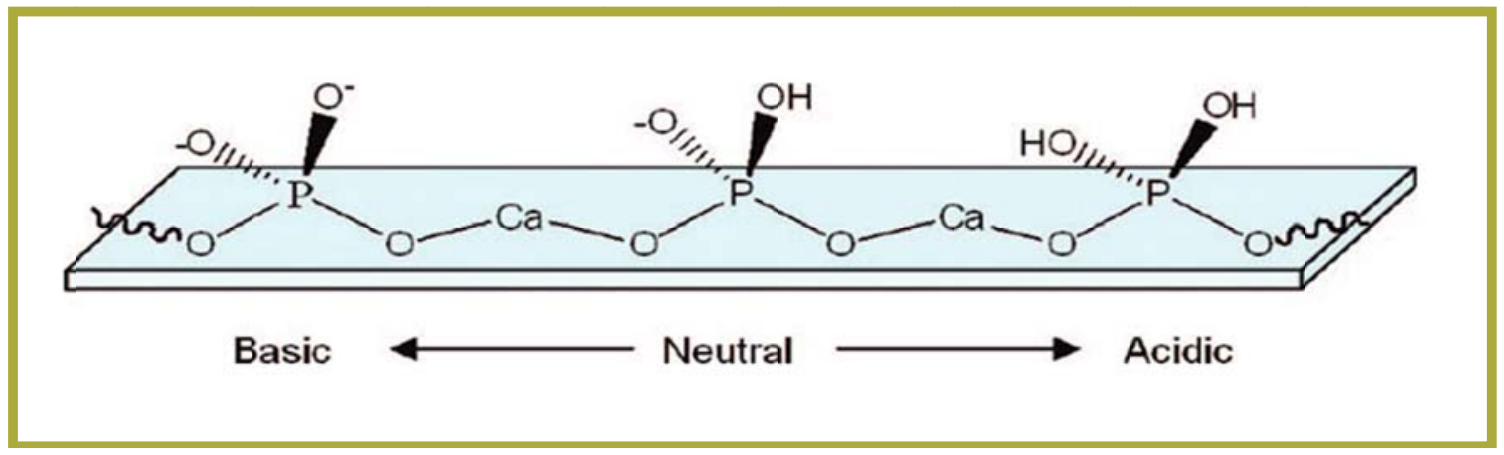

FONTE: Kwon et al., 2009. 
In vitro e in vivo, a protonação da superfície da hidroxiapatita foi relacionada com a capacidade de tamponamento de $\mathrm{H}^{+}$pelo osso e a modificação da composição química óssea em pH ácido. Estudos com calvaria de camundongos neonatos demonstraram que a queda do pH do meio de cultura pela redução da concentração de $\mathrm{HCO}_{3}{ }^{-}$causa fluxo resultante de $\mathrm{H}^{+}$ do meio para a calvaria, indicando então a capacidade tamponante óssea (Figura 6). In vivo, a redução do conteúdo de $\mathrm{CO}_{2}$ ósseo (presente sob a forma de $\mathrm{CO}_{3}{ }^{2-}$ e $\mathrm{HCO}_{3}{ }^{-}$) em animais acidóticos é coerente com a capacidade óssea de tamponamento (Figura 7).

Figura 6 - Relação entre o pH do meio de cultura e o fluxo resultante de $\mathrm{H}^{+}$na acidose metabólica, causada pela redução da concentração de $\mathrm{HCO}_{3}{ }^{-}$. Os valores negativos em "net hydrogen ion flux", no eixo y, correspondem a fluxo de $\mathrm{H}^{+}$resultante do meio para a calvaria, e os valores positivos correspondem a fluxo inverso.

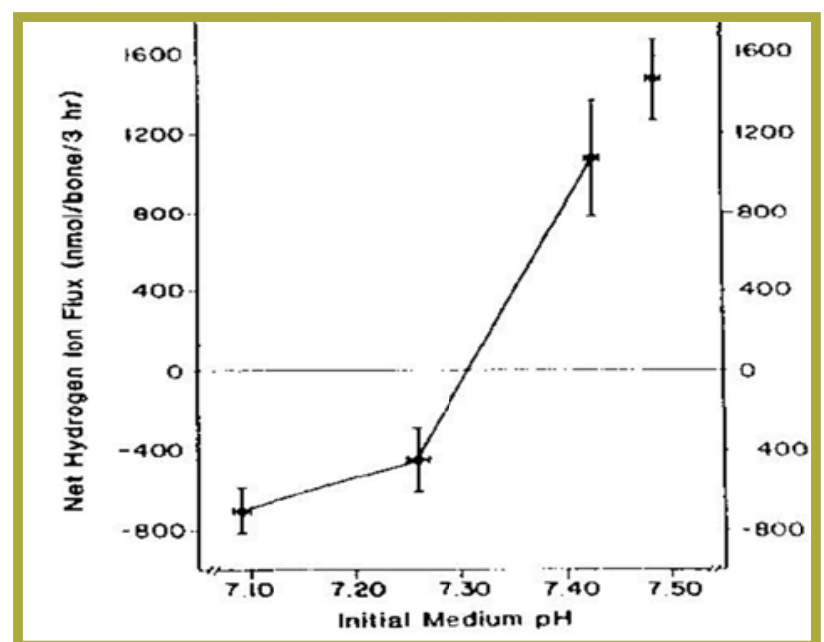

FONTE: Bushinsky, 1989.

Figura 7 - Conteúdo total de $\mathrm{CO}_{2}$ ósseo como função da concentração plasmática de $\mathrm{HCO}_{3}{ }^{-}$. Observa-se redução do $\mathrm{CO}_{2}$ ósseo com a redução da concentração de bicarbonato plasmático.

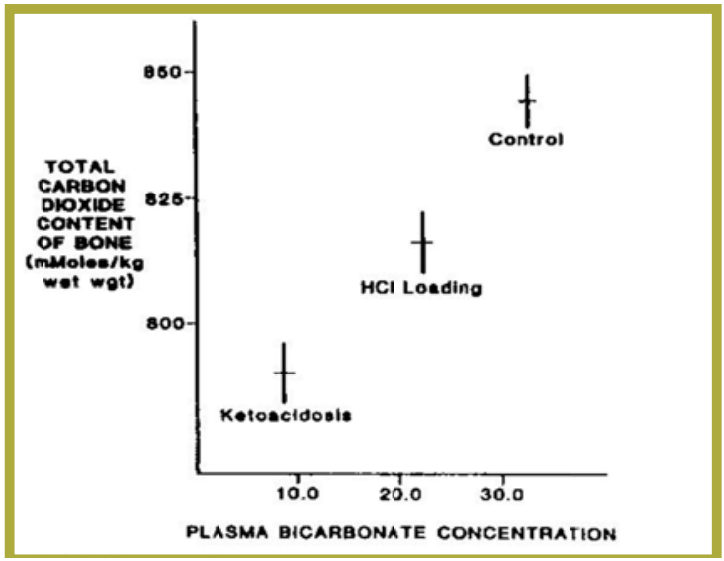

FONTE: Bushinsky, 1989. 
Embora o processo físico-químico de protonação da superfície da hidroxiapatita seja importante na correção da acidose metabólica, esse não ocorre isoladamente, existem mecanismos celulares envolvidos na regulação do equilíbrio ácido-base pelo tecido ósseo. Krieger et al., em 2004, elucidaram alguns mecanismos por meio dos quais a acidose metabólica modifica a fisiologia óssea. De acordo com os autores, a acidose metabólica induz efluxo de $\mathrm{Ca}^{2+}$ do tecido ósseo inicialmente por processo físico-químico de dissolução da hidroxiapatita, de maneira independente de células, e posteriormente por meio da modificação da atividade celular. A acidose suprime a atividade dos osteoblastos e estimula indiretamente a síntese de RANKL, promovendo a diferenciação e atividade de osteoclastos. Consequentemente, há aumento da reabsorção óssea e liberação de tampões como $\mathrm{PO}_{4}{ }^{3-} \mathrm{e}$ $\mathrm{CO}_{3}{ }^{2-}$, que contribuem para o tamponamento extracelular de $\mathrm{H}^{+}$. Posteriormente, Krieger e Bushinsky (2011) acresentaram que o efluxo de $\mathrm{Ca}^{2+}$ do osso induzido por acidose metabólica envolve ativação da sinalização por cálcio intracelular nos osteoblastos, e é mediado por cicloxigenase 2, com produção de RANKL induzida por prostaglandina E2.

Com relação aos efeitos diretos da acidose nos osteoclastos, sabe-se que esta aumenta o número de superfícies reabsorvidas e de sua área (Arnett, Dempster, 1986) (Figura 8); aumenta a formação de podossomos (Teti et al., 1989); estimula a atividade da $\mathrm{H}^{+}$- ATPase (Nordström et al., 1997); aumenta a expressão de genes do receptor de calcitonina e da anidrase carbônica (Biskobing, Fan, 2000); e aumenta a liberação de beta-glucuronidase, enzima envolvida na degradação da matriz orgânica (Krieger et al., 2004).

Figura 8 - Ativação da reabsorção óssea pela acidose. No eixo y está representado o número de escavações por osteoclasto de ratos (A), osteoclastos de galinhas (B), e osteoclastos derivados de osteosarcoma humano (C) cultivados por 24 horas em discos de dentina.

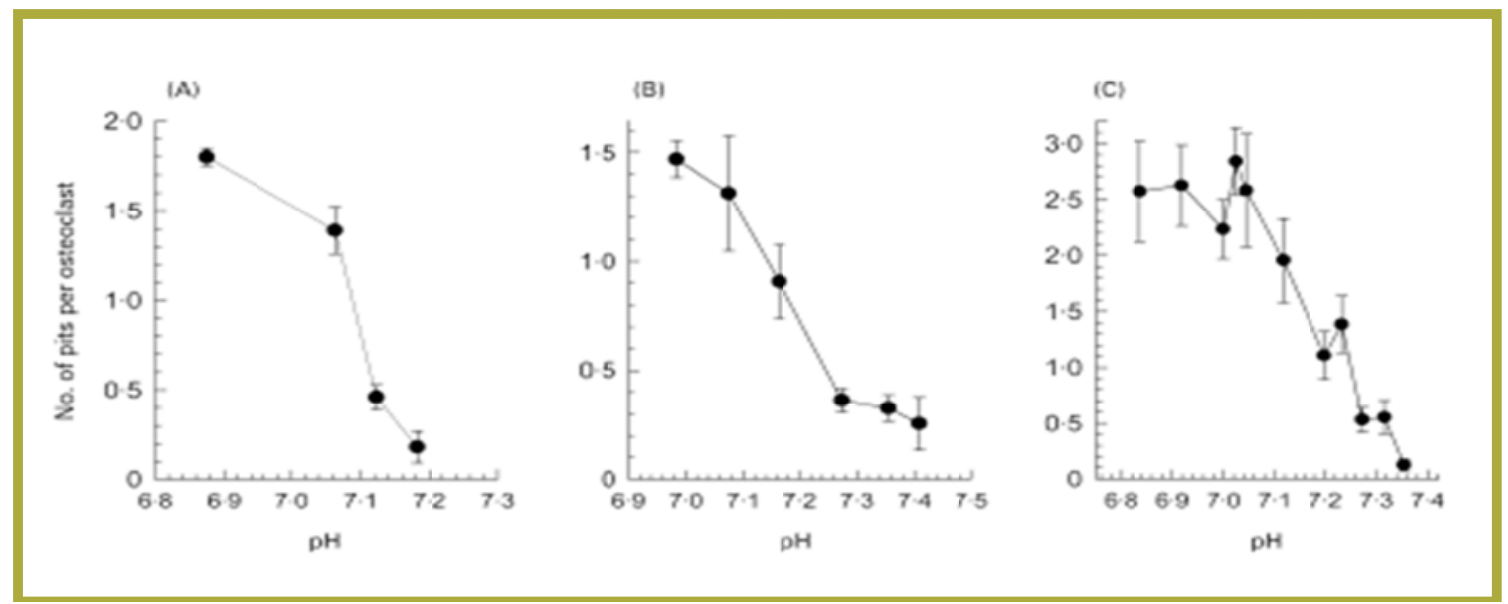

FONTE: Arnett, 2003. 
Entretanto, apesar de haver efeito direto da acidose metabólica sobre a função das células ósseas, é interessante saber que o $\mathrm{pH}$ modifica a constante de equilíbrio do complexo albumina-cálcio, de modo que na acidose reduz-se a ligação, e na alcalose esta é favorecida (Favus, Goltzman, 2008). Portanto, os níveis de cálcio plasmático podem variar com a modificação da concentração de proteínas plasmáticas e com modificações do pH extracelular de maneira independente de células e da dissolução do mineral ósseo.

Para elucidar a relação existente entre o tamponamento de $\mathrm{H}^{+}$extracelular e a integridade óssea, é interessante mencionar a colocação de Green e Kleeman, em um artigo de revisão editorial publicado em 1991:

The linkage between bone and the body acid-base status can be described as both a blessing and a curse. While bone performs this buffering process in the defense against major systemic acid-base perturbations, it is the very same process of buffering which will ultimately lead to dissolution of the bone mineral.

\subsection{FLUIDO EXTRACELULAR ÓSSEO}

O espaço vascular somado ao compartimento extravascular (o espaço entre os vasos sanguíneos e as células de revestimento) compreendem o Fluido Extracelular Sistêmico (FE), o qual banha um dos lados da camada de células de revestimento. Do lado ósseo da camada das células de revestimento (lado antissistêmico), as células de revestimento e osteoblastos estão em íntimo contato com os osteócitos por meio dos prolongamentos citoplasmáticos no interior dos canalículos. O fluido que flui no pequeno espaço entre os prolongamentos celulares dos osteócitos e a parede dos canalículos e nas lacunas dos osteócitos, somado ao fluido adsorvido ao mineral ósseo e às proteínas da matriz, constituem uma subdivisão do fluido extracelular denominada Fluido Extracelular Ósseo (FEO) (Figura 9). 
Figura 9 - Representação esquemática da unidade fisiológica do tecido ósseo. O espaço vascular representado em (A) é constituído por vasos sinusóides e pequenos capilares; em (B) está representado o osteócito; em (C), estão representados os canalículos; em (D) estão representadas "gap junctions" entre osteoblastos; em (E) está representado o tecido conjuntivo entre o vaso sanguíneo e os osteoblastos. A água óssea é dividida em dois compartimentos: a água adsorvida ao mineral ósseo e à matriz orgânica e o fluido fluindo em (C), os quais compõem uma subdivisão do fluido extracelular, denominada FEO. Os fluidos em A e E compõem o FE. A camada de células de revestimento e osteoblastos possivelmente funciona como uma membrana que separa os dois compartimentos. A compartimentalização do FEO é fortemente sugerida pela existência de gradientes iônicos entre FE e FEO.

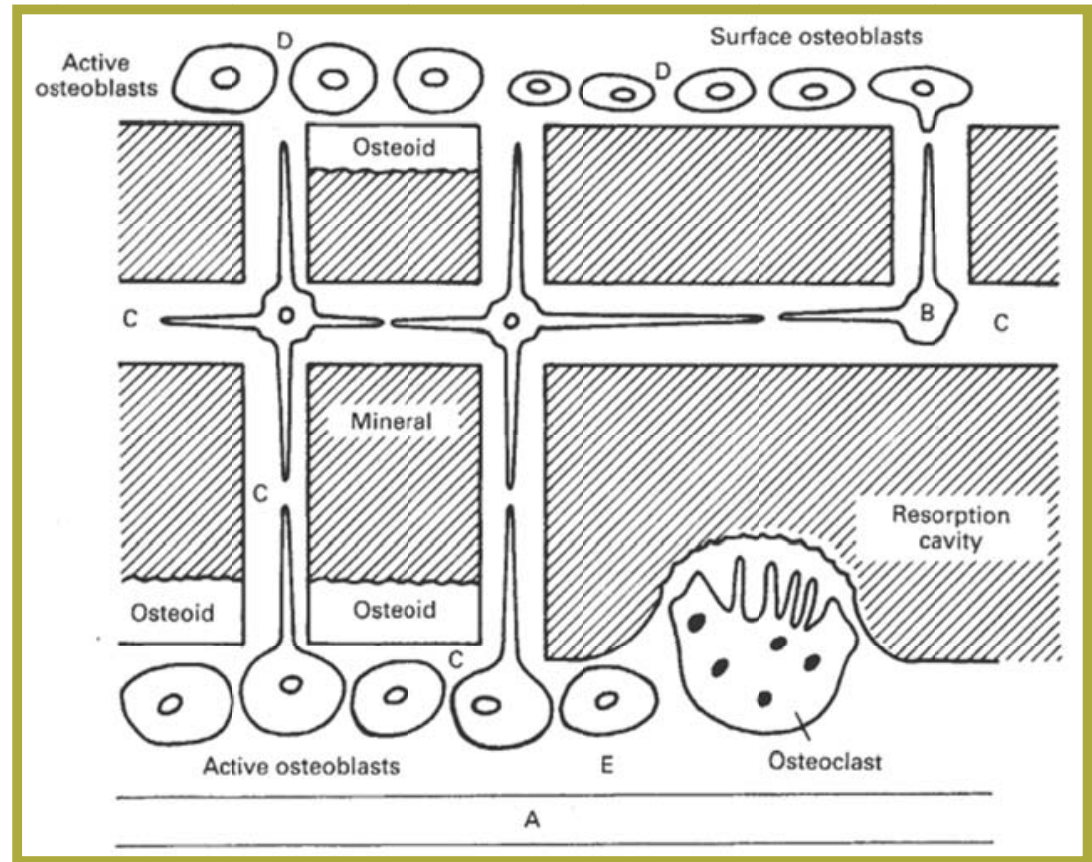

FONTE: Green, Kleeman, 1991.

As respostas celulares à tensão mecânica aplicada no osso compacto têm sido relacionadas ao estresse gerado por movimento do FEO, o qual é movido pela pressão extravascular combinada com a carga mecânica aplicada. O fluxo de fluido impõe um estresse de cisalhamento nos osteócitos que parece deformar as células dentro de suas lacunas e também os prolongamentos celulares no interior dos canalículos (Cowin et al., 1991).

O estresse provocado pelo movimento do fluido nos canalículos induziria mecanossensação nos osteócitos por meio da tensão exercida sobre integrinas, as proteínas celulares envolvidas com a conexão e ancoragem da célula à matriz extracelular (Salter, Robb, Wright, 1997). In vivo, tem sido demonstrado que cargas fisiológicas previnem a apoptose dos osteócitos e, inversamente, a redução da carga mecânica aumenta a apoptose dos osteócitos (Noble et al., 2003; Aguirre et al., 2006). Além disso, há relatos de que os osteócitos submetidos ao fluxo de fluido inibiriam a formação de osteoclastos e a reabsorção óssea (Tan et al., 2007). Os efeitos diretos do estresse de cisalhamento pelo movimento de fluido sobre os osteoclastos não são conhecidos. 
O FEO não está em equilíbrio com o FE, havendo evidências de que o FEO seja compartimentalizado. Segundo Green e Kleeman (1991), a observação de que há um marcado excesso de potássio $\left(\mathrm{K}^{+}\right)$no $\mathrm{FEO}$ em relação ao FE sistêmico compõe um argumento forte a favor da compartimentalização. A concentração de $\mathrm{K}^{+}$na água dos ossos pode ser até 25 vezes maior que a dos fluidos extracelulares em geral (Figura 10). De acordo com os autores, o gradiente de $\mathrm{K}^{+}$existente entre FE e FEO indica seu confinamento no FEO, já que o $\mathrm{K}^{+}$não é incorporado à fase mineral da hidroxiapatita e não se liga ao colágeno, sendo portanto disponível para o intercâmbio com o $\mathrm{K}^{+}$do $\mathrm{FE}$.

Figura 10 - Comparação entre FE (plasma) e FEO (Bone fluid). A concentração de $\mathrm{Ca}^{2+}(\mathrm{Ca})$ no $\mathrm{FEO}$ é menor que no $\mathrm{FE}$, o produto $\mathrm{Ca}: \mathrm{P}$ é muito menor, a concentração de $\mathrm{K}^{+}(\mathrm{K})$ é muito mais alta e as concentrações de $\mathrm{Na}^{+}(\mathrm{Na})$ e $\mathrm{Mg}^{2+}(\mathrm{Mg})$ são menores no $\mathrm{FEO}$ em relação ao $\mathrm{FE}$. Embora algum $\mathrm{K}^{+}$, em geral $20 \%$ ou menos, tenha sido atribuído ao fluido intracelular, $80 \%$ ou mais do $\mathrm{K}^{+}$ósseo provém do FEO.

\begin{tabular}{llllllr} 
& \multicolumn{6}{c}{ Electrolyte content, $m M$} \\
\cline { 2 - 7 } \multicolumn{1}{c}{ Material } & $\mathrm{Ca}$ & $\mathrm{Mg}$ & $\mathrm{K}$ & $\mathrm{Na}$ & $\mathrm{Pi}$ & $\mathrm{Cl}$ \\
\hline Plasma & 1.5 & 0.7 & 4 & 140 & 1.8 & 100 \\
Bone "fluid" & 0.48 & 0.4 & 25 & 125 & 1.8 & 130
\end{tabular}

FONTE: Green, Kleeman, 1991.

As evidências da compartimentalização fisiológica entre FEO e FE indicam a existência de uma barreira funcional que promove diferentes taxas de fluxo iônico a partir do FEO e em direção a este. Adicionalmente, o conhecimento da composição do FEO constitui informação relevante para o melhor entendimento dos mecanismos envolvidos com o transporte iônico no tecido ósseo e, especialmente, nos osteoclastos.

\subsection{OSTEOCLASTOS}

Embora desempenhem suas funções em contiguidade com o osso, os osteoclastos não são células da linhagem óssea, pois têm origem mielóide, sendo derivados de monócitos, assim como os macrófagos. A fusão de células precursoras pode gerar células com diferentes fenótipos e embora haja o conceito de que osteoclastos são multinucleados, é possível que haja células mononucleadas com capacidade reabsortiva. Os osteoclastos são mais frequentes no endósteo, ou seja, no tecido de revestimento interno das cavidades medulares (Figura 11), mas também podem ser encontrados no periósteo, tecido que reveste os ossos externamente e 
que não tem contato com a medula óssea. Os osteoclastos são móveis (Teitelbaum, 2000) e são encontradas geralmente em contato com a superfície óssea, no interior de uma lacuna que é produto de sua atividade reabsortiva (Baron, 1989). Quando ativos, os osteoclastos são polarizados e apresentam diferentes domínios na membrana: 1) uma área de dobras na membrana plasmática (membrana pregueada ou "ruffled border") em contato com a matriz óssea, onde ocorre a reabsorção (Jones, Boyde, 1977); 2) uma região adjacente à membrana pregueada rica em microfilamentos, livre de organelas, caracterizada por um anel de F-actina, que funciona como local de adesão do osteoclasto ao osso (Teti et al., 1991); 3) uma região secretória oposta à membrana pregueada, através da qual os componentes degradados da matriz são liberados para o meio extracelular (Salo et al., 1997) (Figura 12).

Figura 11 - Fotomicrografia onde se observam os osteoclastos (em vermelho intenso) no revestimento interno de cavidades medulares. (Fêmur de camundongo, histoquímica para fosfatase ácida resistente a tartarato - TRAP, marcador de osteoclastos. Aumento: $20 \mathrm{X}$.)

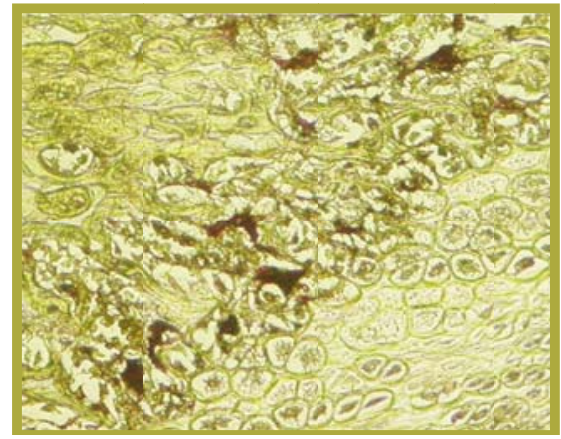

FONTE: Acervo Pessoal.

Figura 12 - Domínios de membrana dos osteoclastos. SZ = sealing zone (anel de F-actina); domínio secretório funcional (apical); ruffled border = membrana pregueada.

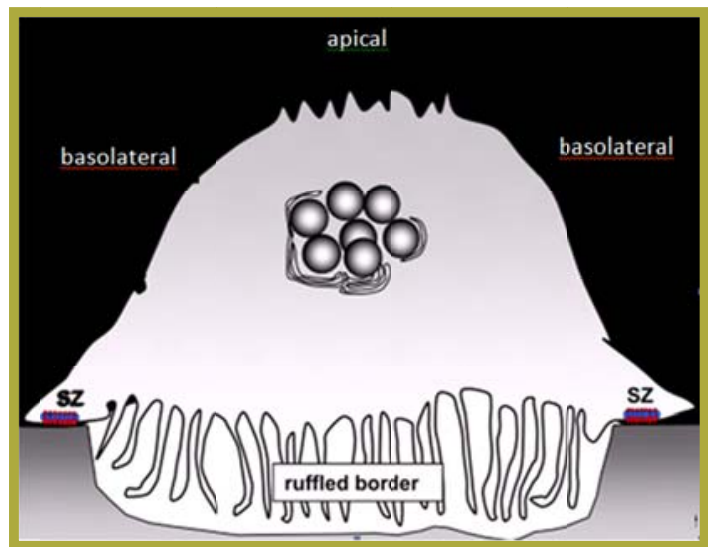

FONTE: Coxon, 2009. 


\subsubsection{Osteoclastogênese}

Os osteoclastos e seus precursores são responsivos a íons, hormônios, citocinas, interações célula-célula e contatos célula-matriz. Entretanto, apenas dois fatores hematopoiéticos são necessários e suficientes para a osteoclastogênese: a citocina da família do Fator de Necrose Tumoral (TNF) RANKL e o polipeptídeo M-CSF ("Macrophage Colony Stimulating Factor"), também nomeado CSF-1 (“Colony-Stimulating Factor-1") (Boyle et al., 2003). O RANKL é uma citocina que permanece ligada à superfície das células de linhagem osteoblástica e também pode ser secretada. A síntese de RANKL ocorre em resposta a hormônios sistêmicos, como vitamina D3, e citocinas, como IL-6. O RANKL e o M-CSF induzem a osteoclastogênese por meio da indução da expressão de genes que caracterizam a linhagem osteoclástica, incluindo-se aqueles que codificam a fosfatase ácida resistente a tartarato (TRAP), a catepsina K e o receptor de calcitonina (Figura 13).

Figura 13 - Osteoclastogênese. Esquema do desenvolvimento da célula precursora hematopoiética em osteoclasto maduro, formado pela fusão de múltiplas células individuais. A maturação ocorre no osso a partir de células mononucleares do sangue periférico comprometidas com a linhagem dos macrófagos. M-CSF e RANKL são essenciais para a osteoclastogênese, e sua ação durante a maturação está representada. OPG (osteoprotegerina) pode se ligar e neutralizar a ação do RANKL, modulando negativamente a osteoclastogênese e a ativação de osteoclastos maduros. Abaixo, estão relacionadas as mutações em genes únicos que bloqueiam a osteoclastogênese e a ativação celular. Aquelas indicadas em itálico são mutações de ocorrência natural em roedores e humanos, enquanto as outras resultaram de mutagênese direcionada. Acima estão as mutações em genes únicos que aumentam a osteoclastogênese e/ou a ativação e a sobrevivência celular e resultam em osteoporose. Note que todos os mutantes representam "knockdown", exceto de OPG e RANKL, que foram superexpressos em modelos transgênicos (em azul).

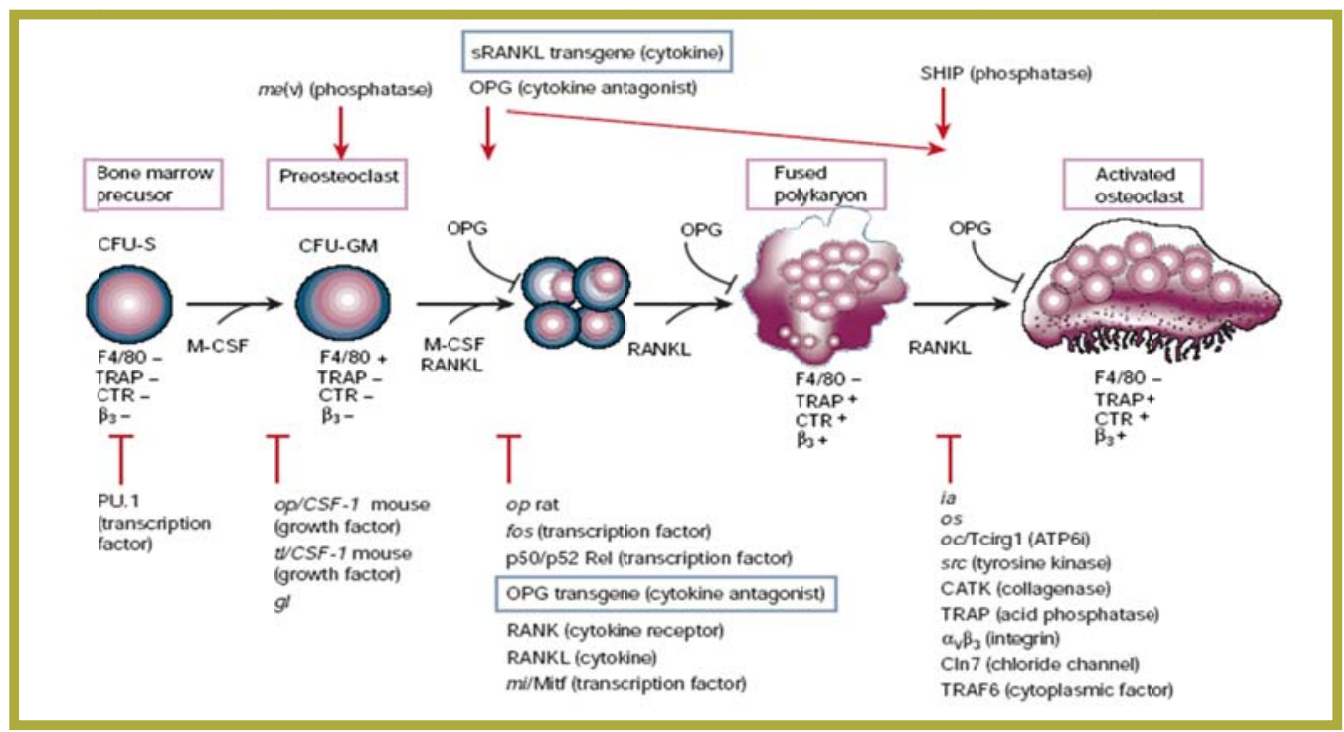

FONTE: Boyle, 2003. 
A regulação da osteoclastogênese também está sujeita à presença de osteoprotegerina (OPG), proteína sintetizada por osteoblastos e que possui afinidade de ligação com o RANKL. A ligação da OPG ao RANKL impede a ativação do receptor RANK nos precursores de osteoclastos (Figura 14) presentes no sangue circulante e na medula óssea (Boyle et al., 2003).

Figura 14 - Regulação da osteoclastogênese por RANKL e OPG. A OPG pode se ligar e neutralizar a ação do RANKL, modulando negativamente a osteoclastogênese.

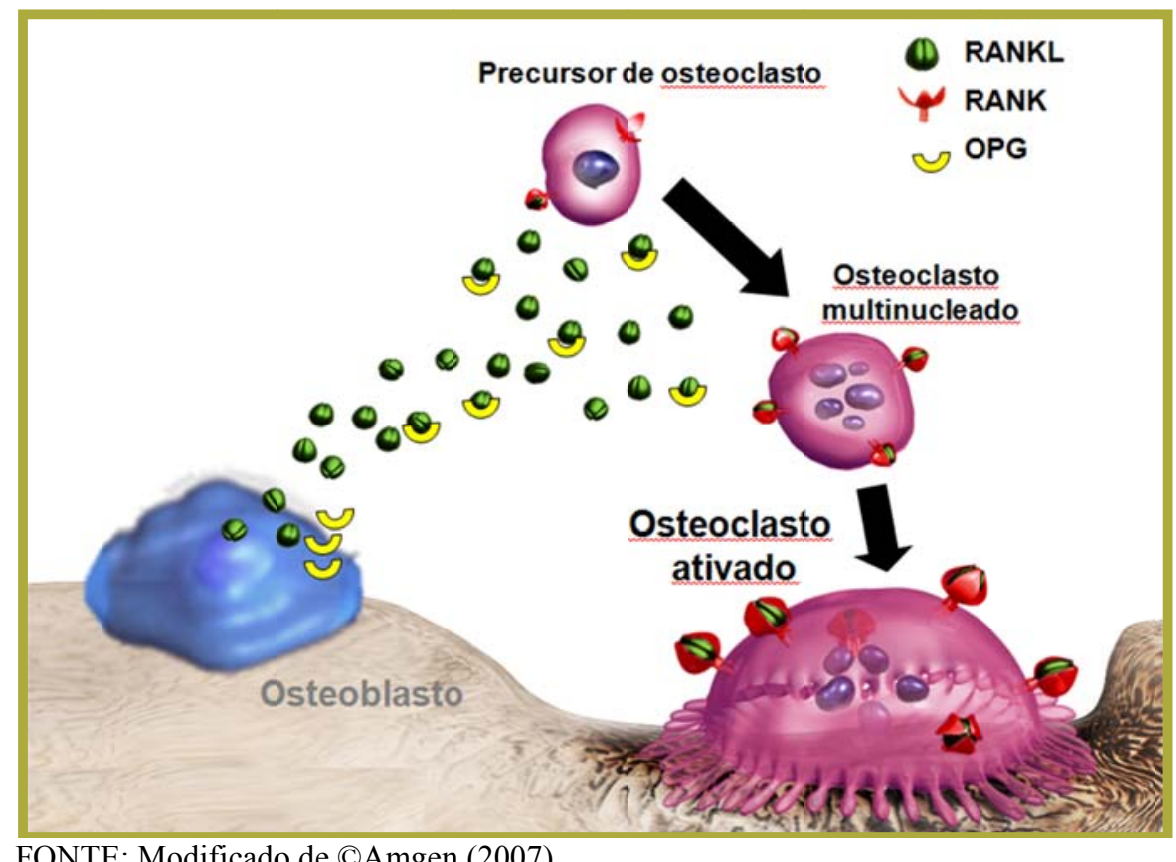

FONTE: Modificado de (CAmgen (2007).

Além dos fatores essenciais para a osteoclastogênese, os estrógenos e uma variedade de hormônios e citocinas modulam esse processo. Dentre os fatores que estimulam a osteoclastogênese, incluem-se as interleucinas (ILs) 1, 6, 11, 15 e 17, assim como o TNF $\alpha$, o PTH e a vitamina D3 (Alsina et al., 2003 apud Zaidi et al., 2003). Dentre os fatores inibidores, destacam-se as ILs 4, 10, 12, 13 e 18, assim como o TGF $\beta$, o interferon $\gamma$ e a calcitonina (Roodman, 2001 apud Zaidi et al., 2003).

Com o desenvolvimento das técnicas de "gene knockout" foi possível distinguir moléculas necessárias para a osteoclastogênese das que simplesmente modulam a função celular. Assim, o bloqueio de genes para diferentes moléculas, tais como PU.1, M-CSF, c-fos, RANKL, RANK, TRAF-6, NF- $\kappa B$, c-src, PI-3-quinase, gelsolina, integrina $\alpha_{\mathrm{v}} \beta_{3}$, catepsina $\mathrm{K}$, TRACP, $\mathrm{H}^{+}$-ATPase vacuolar e anidrase carbônica, resulta em osteoclastos não-funcionais ou 
com falhas na formação (Grigoriadis et al., 1994; Tondravi et al., 1997; Zaidi et al., 2003).

\subsubsection{Biologia Celular do Osteoclasto - Secreção de Ácido}

A secreção de $\mathrm{H}^{+}$pelo osteoclasto através da membrana pregueada promove a acidificação da superfície óssea no volume delimitado pelo anel de actina e desempenha papel fundamental na reabsorção óssea (Baron et al., 1985; Silver et al., 1988; Francis et al., 2002).

A primeira demonstração da existência de uma zona ácida adjacente aos osteoclastos foi realizada por Baron et al. (1985), utilizando laranja de acridina, substância fluorescente indicadorade modificações de $\mathrm{pH}$ intracelular. Adicionalmente, foi demonstrado, por meio de microeletrodos sensíveis a variações de $\mathrm{pH}$, que osteoclastos aderentes podem reduzir o $\mathrm{pH}$ na zona de contato com o frasco de cultura a um valor de $\mathrm{pH} \mathrm{3,0} \mathrm{ou} \mathrm{menos} \mathrm{em} \mathrm{apenas} \mathrm{poucos}$ minutos. Valores mais altos de $\mathrm{pH}$ foram observados quando as medidas foram realizadas in situ em osteoclastos aderidos a fragmentos de osso osteoporótico, em que o valor médio foi de 6,01 (Silver et al., 1988).

Medidas com microeletrodos contendo resina neutra de troca iônica sensível a $\mathrm{H}^{+}$ou $\mathrm{Ca}^{2+}$ indicaram ainda que os valores mais baixos de $\mathrm{pH}$ na lacuna de reabsorção tendem a coincidir com as concentrações mais altas de $\mathrm{Ca}^{2+}$, que variaram de 17 a $40 \mathrm{mM}$. Esse dado

sugere que à medida que o $\mathrm{pH}$ é reduzido pelo acúmulo de prótons $\left(\mathrm{H}^{+}\right)$, os íons $\mathrm{Ca}^{2+}$ são liberados dos cristais de hidroxiapatita. Hoje se sabe que, para descalcificar o tecido ósseo e degradar a matriz orgânica, o osteoclasto precisa secretar de 1 a $2 \mathrm{H}^{+}$para cada $\mathrm{Ca}^{2+}$ transferido para o meio interno (Francis et al., 2002).

Medidas do $\mathrm{pH}$ pericelular sob osteoclastos em cultura mostram que a região ácida não se inicia na extremidade da região de adesão, mas a aproximadamente $10 \mu \mathrm{m}$ da borda extrema visível da membrana pregueada, onde há formação de um selo entre o ambiente geral e a superfície a ser reabsorvida. Assim, condições especiais são mantidas no microambiente delimitado pela região de adesão (Silver et al., 1988). Estudos de microscopia eletrônica de varredura confirmam esse achado, uma vez que demonstraram a existência de uma cavidade no osso formada unicamente na área aposta à membrana pregueada (Silver et al., 1988).

Além de ser importante para a dissolução mineral, a secreção ácida estabelece, na lacuna de reabsorção, o pH adequado para a atividade de enzimas que degradam a matriz orgânica. As enzimas colagenolíticas como a catepsina K (principal hidrolase ácida secretada 
na interface osso-osteoclasto) (Garnero et al., 1998) e outras proteases, secretadas pelo osteoclasto, têm maior atividade em $\mathrm{pH}$ ácido.

\subsubsection{Proteínas Transportadoras de $\mathrm{H}^{+}$no Osteoclasto}

Boa parte da informação disponível na literatura acerca das proteínas que fazem transporte de $\mathrm{H}^{+}$no osteoclasto resulta de estudos de recuperação do pHi após carga ácida intracelular (Teti et al., 1989; Zaidi et al., 2003; Khadeer et al., 2003; Bouyer et al., 2007).

Grano et al. (1994) demonstraram que, em "osteoclast-like cells", a inibição do trocador $\mathrm{Na}^{+} / \mathrm{H}^{+}$não eliminou completamente a capacidade de regulação do pHi dessas células. Blair et al. (1991), em estudos de acidificação de vesículas ("inside-out”) derivadas de membrana pregueada de osteoclastos de aves, demonstraram que o transporte iônico responsável pela acidificação da interface célula-osso não é dependente de $\mathrm{Na}^{+}$ou $\mathrm{K}^{+}$, de modo que a substituição total do $\mathrm{Na}^{+}$ou a imposição de grandes gradientes de $\mathrm{Na}^{+}$ou $\mathrm{K}^{+}$não afetaram significativamente o transporte de prótons nas vesículas.

Com relação à $\mathrm{H}^{+} / \mathrm{K}^{+}$-ATPase, os dados apresentados na literatura são controversos. Enquanto alguns autores sugerem que o transportador não está presente na membrana do osteoclasto (Nordström et al., 1995; Vaananen et al., 1990), outros apontam a $\mathrm{H}^{+} / \mathrm{K}^{+}$-ATPase como um mecanismo efetivo na regulação do pHi e na acidificação da lacuna de reabsorção (Mizunashi et al., 1993). Para averiguar a participação da $\mathrm{H}^{+} / \mathrm{K}^{+}$-ATPase, do tipo gástrico, na acidificação vesicular, Blair et al. (1991) empregaram ortovanadato de sódio (1 mM), inibidor do transportador, e não observaram redução da acidificação.

A $\mathrm{H}^{+}$-ATPase, ou bomba de $\mathrm{H}^{+}$, é o mecanismo reconhecido como efetor da secreção vetorial de prótons na lacuna de reabsorção (Nordström et al., 1995). Reconhece-se também a importância do transporte paralelo de cloreto $\left(\mathrm{Cl}^{-}\right)$por meio de canais, especialmente do tipo CLC7 (Kelly et al., 1994). Portanto, o paradigma vigente acerca do mecanismo de reabsorção óssea fundamenta-se na atividade conjunta da $\mathrm{H}^{+}$-ATPase vacuolar e dos canais para cloreto CLC7 (Figura 15).

Com relação ao transporte de base, há evidência de que o trocador $\mathrm{Cl}^{-} / \mathrm{HCO}_{3}{ }^{-}$é responsável por parte do mecanismo de homeostase do $\mathrm{pH}$ intracelular (pHi) de osteoclastos de aves, corrigindo a alcalinização ocasionada pela secreção de ácido (Teti et al., 1989). 
Adicionalmente, Bouyer et al. (2007) demonstraram que, em células de mamíferos, o cotransportador $\mathrm{Na}^{+}-\mathrm{HCO}_{3}{ }^{-}$promove a alcalinização intracelular na presença de M-CSF.

Figura 15 - Mecanismos de transporte envolvidos na acidificação da matriz óssea e homeostase iônica em osteoclastos de mamíferos. Na membrana pregueada, estão representados a $\mathrm{H}^{+}$-ATPase (roxo) e o trocador $\mathrm{Cl}^{-} / \mathrm{H}^{-} \mathrm{CLC} 7$ (fúcsia).

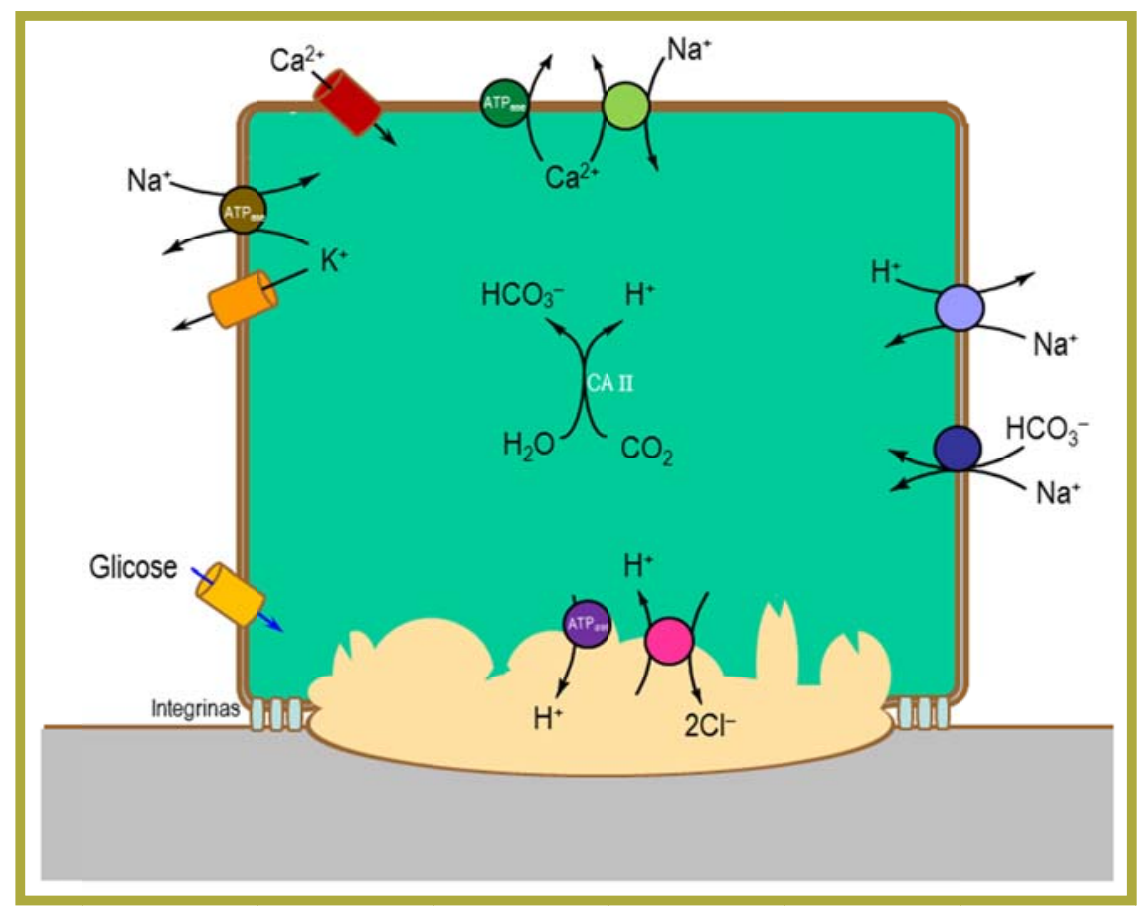

\subsubsection{1 $\mathrm{H}^{+}$ATPase}

As $\mathrm{H}^{+}$-ATPases são divididas nos tipos $\mathrm{F}, \mathrm{V}$ e $\mathrm{P}$ e compartilham sequências e mecanismos de ação. As do tipo $\mathrm{F}$ estão presentes em cloroplasto, mitocôndria e bacterias, as do tipo $\mathrm{V}$, de vacuolar, estão presentes em organelas, e as do tipo $\mathrm{P}$ estão presentes em plantas, fungos e bactérias (DeCoursey, 2003). Entre as P-ATPases estão a $\mathrm{Na}^{+}-\mathrm{K}^{+}$-ATPase, a $\mathrm{H}^{+} / \mathrm{K}^{+}$-ATPase e a $\mathrm{Ca}^{2+}$-ATPase, que se caracterizam pela habilidade de sofrer fosforilação durante seus ciclos catalíticos, além de utilizarem ATP para a transferência de íons através de membranas. Já as F-ATPases acoplam o movimento de prótons à síntese de ATP. 
O mecanismo celular primário responsável pela acidificação da interface ossoosteoclasto é atribuído à $\mathrm{H}^{+}$-ATPase vacuolar (V-ATPase), bomba de prótons localizada na membrana pregueada, que extrui ativamente $\mathrm{H}^{+}$para o meio extracelular (Vaananen et al., 1990; Nordström et al., 1995).

Análises biológicas e genéticas revelaram que as V-ATPases são compostas por um domínio $\mathrm{V}_{1}$, citosólico, responsável pela hidrólise do $\mathrm{ATP}$, e um domínio $\mathrm{V}_{0}$, transmembrânico, responsável pela translocação dos prótons $\left(\mathrm{H}^{+}\right)$. $\mathrm{O}$ domínio $\mathrm{V}_{1}$, de aproximadamente $640 \mathrm{kDa}$, contém oito subnunidades $(\mathrm{A}-\mathrm{H})$ e o domínio $\mathrm{V}_{0}$, de aproximadamente $260 \mathrm{kDa}$, contém pelo menos quatro diferentes subunidades (a, c, d, e) (Figura 16) e duas subunidades acessórias recentemente descobertas, Ac45 e M8-9 (Yao et al., 2007).

Figura 16 - Ilustração esquemática das V-ATPases. A proteína é composta por um domínio periférico $V_{1}$ e um domínio $\mathrm{V}_{0}$ associado à membrana. $\mathrm{O}$ domínio $\mathrm{V}_{1}$ é constituído por oito subunidades $(\mathrm{A}-\mathrm{H})$ e é responsável pela hidrólise do ATP. O domínio $\mathrm{V}_{0}$ é constituído por quatro subunidades (a, c, d, e) e é responsável pela translocação dos prótons.

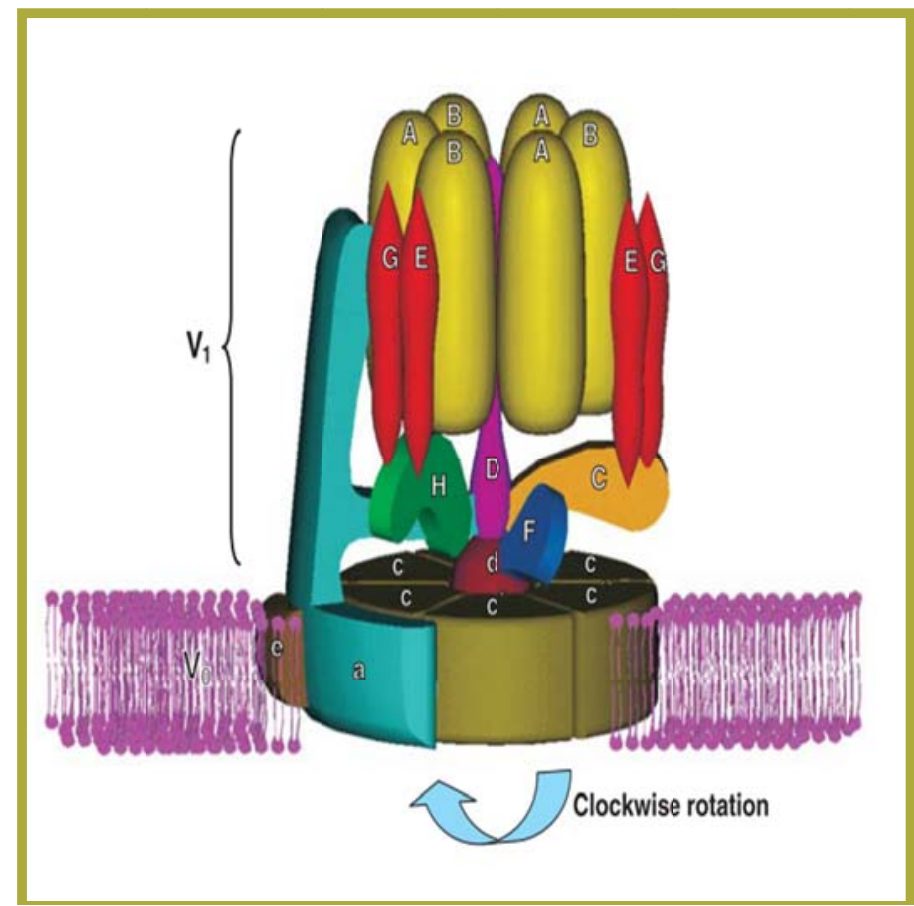

FONTE: Carraro-Lacroix et al., 2009.

As V-ATPases são inibidas por dicyclohexylcarbodiimide (DCCD), um inibidor clássico das $\mathrm{H}^{+} \mathrm{ATPases}$, e são potentemente inibidas por bafilomicina $\mathrm{A} 1$, a qual se liga à 
subunidade c e bloqueia o fluxo de $\mathrm{H}^{+}$. A inibição da $\mathrm{H}^{+}$-ATPase por bafilomicina $\mathrm{A} 1$, assim como a inibição da anidrase carbônica, inibe a reabsorção de tecido mineralizado in vitro (Sahara et al., 2003).

Há indícios de que a isoforma de V-ATPase presente na membrana pregueada do osteoclasto seja diferente daquela presente na membrana de organelas intracelulares, tais como lisossomos, do mesmo tipo celular ( $\mathrm{Li}$ et al., 1999). Adicionalmente, a proteína expressa subunidades diferentes das expressas em rim e fígado (Breton, Brown, 2007), o que indica que a V-ATPase na membrana pregueada do osteoclasto é uma proteína estruturalmente e funcionalmente única. A $\mathrm{H}^{+}$-ATPase vacuolar do osteoclasto apresenta perfil farmacológico peculiar, uma vez que pode ser inibida por vanadato, um inibidor clássico de P-ATPases, quando em altas concentrações (Chatterjee et al., 1992 apud Francis et al., 2002).

Estudos funcionais em cultura celular confirmam a importância da $\mathrm{H}^{+}$-ATPase na reabsorção óssea e da presença das anidrases carbônicas (ACs), enzimas que catalisam a hidratação e desidratação do $\mathrm{CO}_{2}$, de acordo com a reação:

$$
\mathrm{CO}_{2}+\mathrm{H}_{2} \mathrm{O} \leftrightarrow \mathrm{H}_{2} \mathrm{CO}_{3} \leftrightarrow \mathrm{HCO}_{3}^{-}+\mathrm{H}^{+}
$$

$\mathrm{O} \mathrm{H}^{+}$gerado nesta reação é transportado pela $\mathrm{H}^{+}$-ATPase (Lehenkari et al., 1998).

A extrusão de prótons dependente da $\mathrm{H}^{+}$-ATPase é regulada por diversos mecanismos, os quais incluem: 1) controle da expressão de subunidades em células especializadas; 2) direcionamento de vesículas intracelulares contendo $\mathrm{H}^{+}$-ATPase para a membrana plasmática e reciclagem dessas vesículas entre a membrana e o citosol; 3) dissociação reversível dos domínios $\mathrm{V}_{0}$ e $\mathrm{V}_{1}$; e 4) modulação da razão entre a hidrólise de ATP e o bombeamento de prótons (Breton, Brown, 2007).

A reciclagem da V-ATPase é regulada pelo citoesqueleto. Constituído por dinâmicos filamentos de actina e miosina, o citoesqueleto pode regular a distribuição subcelular de vesículas que contém $\mathrm{H}^{+}$-ATPase e a inserção da proteína na membrana plasmática. Algumas subunidades da V-ATPase podem interagir diretamente ou indiretamente com o citoesqueleto de actina (Breton, Brown, 2007). Lee et al. (1999) demonstraram a interação direta da VATPase com a actina e observaram que tal interação varia de acordo com o estado de atividade do osteoclasto. Propuseram que a V-ATPase, ligada a filamentos de actina, é transportada em direção à membrana pregueada pela contração do complexo actina-miosina II, e depois é desligada da actina para a formação da membrana pregueada. 
Posteriormente, Chen et al. (2004) demonstraram a ligação da V-ATPase à F-actina e não à G-actina, e observaram que o aumento da interação da V-ATPase com a actina coincide com a internalização da bomba de prótons e a perda da atividade reabsortiva dos osteoclastos, sendo decorrente da inibição da fosfatidilinositol 3-quinase (PI3-K). A regulação do citoesqueleto de osteoclastos dependente de polifosfoinositídeos também foi demonstrada por Biswas et al. (2004). Fosfoinositídeos, especialmente fosfatidilinositol 4,5 bifosfato (PIP2), regulam diversas proteínas de ligação à actina, incluindo-se gelsolina, profilina, $\alpha$-actinina e vinculina, para promover a polimerização da actina. A gelsolina controla a montagem e desmontagem da actina, e, além de se ligar à actina, essa proteína também se associa à PI3-K e a polifosfoinositídeos. A ligação de PIP2 à gelsolina causa a liberação da gelsolina da extremidade do filamento de actina, promovendo um local para a rápida adição de monômeros. Adicionalmente, em células do epidídimo, demonstrou-se que a manutenção do citoesqueleto de actina em um estado despolimerizado pela gelsolina facilita o acúmulo apical de V-ATPase dependente de $\mathrm{Ca}^{2+}$ (Beaulieau et al., 2005).

\subsubsection{Canais para cloreto}

Evidências da importância dos canais para cloreto na reabsorção óssea surgiram em 1991, quando Blair et al. demonstraram em vesículas derivadas de membrana pregueada de osteoclastos de aves que a acidificação dada pela $\mathrm{H}^{+}$-ATPase depende de uma condutância a ânion, e se relaciona de modo não-linear com a concentração externa de $\mathrm{Cl}^{-}$. Atualmente, tal importância está ilustrada pela osteopetrose em decorrência da perda dos canais CLC7 (Figura 17) (Kornak et al., 2001). 
Figura 17 - Canais para $\mathrm{Cl}^{-}$da família CLC. Os canais CLC7 são expressos em lisossomos e na membrana pregueada de osteoclastos, (Edwards et al., 2006) e, assim como CLC-4 e CLC-5, podem exibir também atividade de trocador $\mathrm{Cl}^{-} / \mathrm{H}^{+}$, com transporte eletrogênico de $2 \mathrm{Cl}^{-}$para cada $\mathrm{H}^{+}$ transportado.

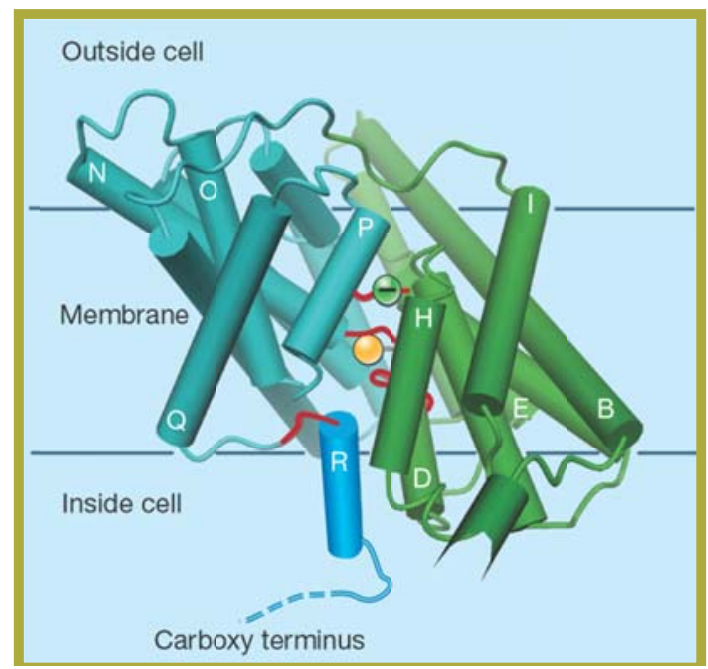

FONTE: Jentsch, 2002.

Com base no fato de que CLC7 e mesmo a $\mathrm{H}^{+}$-ATPase são proteínas lisossomais, Zhao e Rhoss (2007) postularam que as vesículas secretórias que se fundem com a membrana plasmática do osteoclasto para formar a membrana pregueada são de origem lisossomal ou se relacionam a essa organela. Os autores demonstraram que a perda de synaptotagmina VII, proteína que regula a exocitose, inibe a secreção enzimática lisossomal em osteoclastos. Em acordo com esses autores, há evidências do trabalho de Okamoto et al. (2008), que mostram que os canais ClC-3 são expressos em endossomos tardios e lisossomos de osteoclastos de camundongos e contribuem para a reabsorção óssea in vitro por meio da acidificação das organelas.

Adicionalmente à presença de CLC-3 e CLC-7, também se demonstrou a presença de CLIC5 ("intracellular chloride channel 5"). Schlesinger et al. (1997) isolaram da membrana pregueada de osteoclastos de aves um canal para cloreto com peso molecular de $62 \mathrm{kDa}$, proteína homóloga da CLIC5 humana, de expressão intracelular. Em bicamadas planas, o canal da membrana pregueada foi inibido por stilbene-sulfonato e apresentou retificação para fora.

Considerando o fato de que diferentes canais da família CLC participam da acidificação na via endossomal, com ClC-4 e ClC-5 presentes nos endossomos precoces, $\mathrm{ClC}$ 6 nos endossomos tardios, e ClC-7 nos lisossomos, Graves et al. (2008) especulam que a identidade do transportador CLC pode variar de modo a ajustar o $\mathrm{pH}$ final de cada organela da via endocítica. 
A interdependência da secreção ácida e de cloreto na reabsorção óssea foi destacada por Kelly et al., em 1994. Esses autores apontaram que os canais para $\mathrm{Cl}^{-}$participariam da dissipação da diferença de potencial transmembrânico que resulta do transporte eletrogênico de prótons durante a reabsorção óssea. No entanto, pode haver outros mecanismos regulatórios, como um papel direto específico do $\mathrm{Cl}^{-}$na estimulação da atividade da $\mathrm{H}^{+}$ATPase, como apontado por Hilden et al. (1988) apud Carraro-Lacroix et al. (2009). De acordo com esses autores, o papel dos canais para $\mathrm{Cl}^{-}$na função da $\mathrm{H}^{+}$-ATPase não é somente explicado por estabelecimento ou dissipação de uma diferença de potencial através das membranas celulares.

\subsubsection{Canais para $\mathrm{H}^{+}$dependentes de voltagem}

Bouyer et al. (2007), em estudos de recuperação do pH intracelular (pHi) de osteoclastos na ausência do tampão $\mathrm{CO}_{2} / \mathrm{HCO}_{3}{ }^{-}$, concluíram que a secreção de $\mathrm{H}^{+}$após carga ácida intracelular é mediada quase exclusivamente pelo trocador $\mathrm{Na}^{+} / \mathrm{H}^{+}$, pela $\mathrm{H}^{+}$-ATPase e por uma condutância a $\mathrm{H}^{+}$; entretanto, Nordström et al. (1995) afirmam que a condutância a $\mathrm{H}^{+}$é o principal mecanismo independente de $\mathrm{Na}^{+}$que regula o pHi após carga ácida intracelular, em detrimento da $\mathrm{H}^{+}$-ATPase, à qual os autores atribuem mínima participação.

Os canais para prótons destacam-se por sua surpreendentemente alta taxa de extrusão de $\mathrm{H}^{+}$, aproximadamente 100 vezes maior que a de bombas e trocadores, e acredita-se serem responsáveis por compensações rápidas do desbalanço de $\mathrm{pH}$ através da membrana plasmática (Mori et al., 2003). São perfeitamente seletivos a prótons $\left(>10^{6}\right.$ vezes mais permeáveis a $\mathrm{H}^{+}$ que a outros íons), operam preferencialmente com a despolarização da membrana, são fortemente retificadores para fora e apresentam dependência de temperatura na condutância e na cinética do "gating”. São inibidos por $\mathrm{Zn}^{2+}, \mathrm{Cd}^{2+}$ e outros cátions metálicos polivalentes, mas são resistentes ao bloqueio por íons orgânicos (DeCoursey, 2003).

Os canais para prótons dependentes de voltagem são entidades "ion channel-like" caracterizados por propriedades que os distinguem de outros canais iônicos e de transportadores de prótons e foram descritos pela primeira vez como entidades distintas de outras vias de transferência de prótons por Thomas e Meech, em 1982 (DeCoursey, 2003). Um esquema da topologia do canal está representado na Figura 18. 
Figura 18 - Modelo dimérico do canal para próton dependente de voltagem de humanos. Em (a), vê-se a topologia do canal na região transmembrânica vista pelo lado extracelular; em (b), vê-se uma representação do dímero, com as regiões transmembrânicas nomeadas.

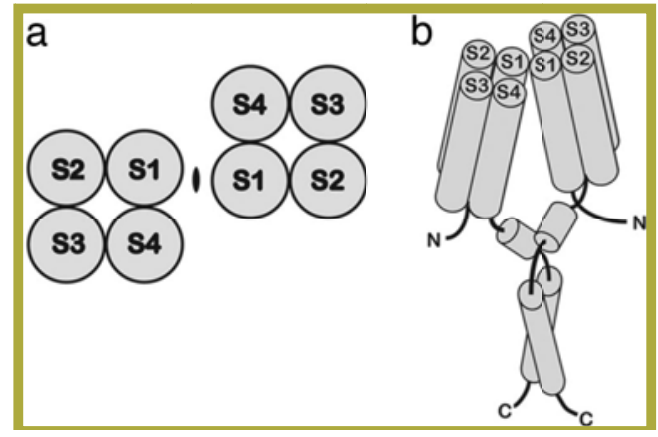

FONTE: Lee, Letts, MacKinnon, 2008.

A dependência de voltagem desses canais não é absoluta, mas fortemente modulada pelo gradiente de $\mathrm{pH}$ através da membrana (Figura 19). O mecanismo de abertura ("gating") é bastante sensível ao $\mathrm{pHi}$ e $\mathrm{pH}$ extracelular $(\mathrm{pHe})$, de modo que a amplitude da corrente e a taxa de ativação são reduzidas pela redução do pHe, com deslocamento da relação correntevoltagem (I-V) para valores de voltagem mais negativos quando há aumento da diferença entre pHi e pHe ou $\Delta$ pH (Mori et al., 2003). Segundo DeCoursey (2003), o grau de protonação de aminoácidos tituláveis (os quais formam parte da via de condução dos prótons e são acessíveis às soluções extracelular e intracelular) determina a responsividade dos canais para prótons ao $\mathrm{pH}$.

Figura 19 - Propriedades biofísicas das correntes por canais para prótons dependentes de voltagem expressos por transfecção em célula HM1. Foram aplicadas despolarizações em "steps" de $5 \mathrm{mV}$ para deflagrar correntes de $\mathrm{H}^{+}$para fora da célula. Correntes de cauda para dentro da célula, características de desativação, foram registradas com aplicação de $-80 \mathrm{mV}$. O registro das correntes demonstra claramente a dependência de gradiente de $\mathrm{pH}$ e de voltagem na determinação da magnitude das correntes.

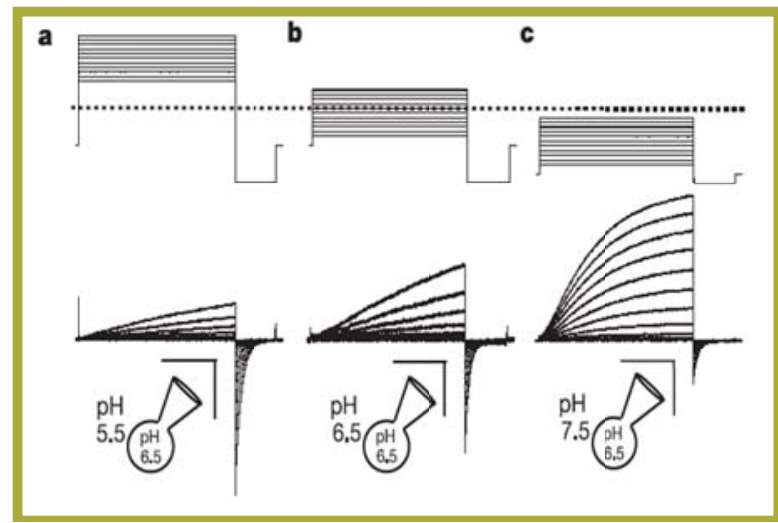

FONTE: Ramsey et al., 2006. 


\section{OBJETIVOS}

Tendo sido considerados os dados da literatura acerca dos efeitos da acidose metabólica sobre a integridade do tecido ósseo, este trabalho teve por objetivo investigar se a acidose metabólica (redução da concentração de $\mathrm{HCO}_{3}{ }^{-}$extracelular) modifica a diferenciação de células precursoras em osteoclastos (1). Adicionalmente, tendo sido consideradas as informações acerca do fluido extracelular ósseo, este trabalho teve por objetivo avaliar se as modificações no fluxo de fluido extracelular modificam a secreção de prótons e a regulação do pHi de osteoclastos na ausência de $\mathrm{HCO}_{3}^{-}$(2), bem como a participação das proteínas $\mathrm{H}^{+}$ATPase, CLC7 e canais para prótons dependentes de voltagem (3) nos processos (1 e 2) citados acima. 


\section{Materiais e MÉtodos}

\subsection{ISOLAMENTO E CULTIVO DE OSTEOCLASTOS DIFERENCIADOS IN VIVO}

Osteoclastos maduros, seus precursores, outras células ósseas e da medula óssea foram removidos, sob condições assépticas, de ossos longos de ratos Wistar de dois a seis dias de idade, de ambos os sexos. Os animais foram anestesiados com anestésico dissociativo, Tiletamina + Zolazepam, $50 \mathrm{mg} / \mathrm{kg}$ de peso do animal, por via intramuscular, nos músculos posteriores da coxa. Os ossos longos foram removidos por cortes nas regiões das epífises, mantendo-se apenas as diáfises e, após a remoção dos tecidos moles por fricção em papel e/ou raspagem, foram transferidos para tubos estéreis contendo meio de cultura $\alpha$-MEM (“Modified Eagles's Médium”, Gibco) gelado. Os tubos contendo os ossos foram mantidos em caixas de isopor com gelo até o final da cirurgia, ou seja, até a remoção de todos os ossos longos, e durante o transporte para a câmara de fluxo laminar de ar. Após a remoção dos ossos longos, os animais foram sacrificados com cloreto de potássio $(\mathrm{KCl} 3 \mathrm{M})$ por injeção intracardíaca. Na câmara de fluxo laminar, os ossos foram lavados com meio de cultura e transferidos para placas de Petri apoiadas sobre bolsas de gelo recicláveis. Os ossos foram então fragmentados com lâmina de bisturi e tesoura delicada, até que ficassem em fragmentos suficientemente pequenos a ponto de não mais poderem ser cortados por esses instrumentos. Os fragmentos foram então agitados por pipetagem para o desprendimento das células. Após 30 segundos para a sedimentação dos fragmentos, foi colhido o sobrenadante contendo as células. O sobrenadante foi então centrifugado a $1.000 \mathrm{~g}$, durante 3 minutos. As células compactadas no fundo do tubo pela centrifugação foram ressuspensas em meio de cultura $\alpha$ MEM, contendo, por litro, $20 \mathrm{UI}$ de penicilina G, $20 \mu \mathrm{g}$ de estreptomicina e 0,05 $\mu \mathrm{g}$ de anfotericina $\mathrm{B}$, além de $10 \%$ de soro fetal bovino e $20 \mathrm{mM}$ de HEPES (ácido N-2hidroxietilpiperazina-N'-2-etanossulfônico). As culturas foram contadas em câmara de Neubauer utilizando corante vital "tripan blue" e semeadas à densidade de $5 \times 10^{6}$ células $/ \mathrm{ml}$ sobre lamínulas de vidro tratadas com poli-l-lisina ou plástico e mantidas em ambiente com $5 \% \mathrm{CO}_{2}$ a $37{ }^{\circ} \mathrm{C}\left(\mathrm{pH} \mathrm{7,4}\right.$; osmolalidade $300 \mathrm{mOsm} / \mathrm{kg}$ de $\left.\mathrm{H}_{2} \mathrm{O}\right)$, em uma incubadora de $\mathrm{CO}_{2}$ (Lab-Line Instruments, Melrose Park, IL) por pelo menos duas horas antes dos experimentos. 


\subsection{DIFERENCIAÇÃO DE OSTEOCLASTOS IN VITRO}

Os osteoclastos foram gerados pelo método de diferenciação descrito por Arnett et al. (2003). Foram isolados os ossos longos de ratos Wistar de 6 a 8 semanas de ambos os sexos, anestesiados com anestésico dissociativo, Tiletamina + Zolazepam, $50 \mathrm{mg} / \mathrm{kg}$ de peso do animal, por via intramuscular, nos músculos posteriores da coxa. As epífises foram removidas, e as medulas ósseas foram coletadas por injeção de PBS ("phosphate buffered saline") estéril na cavidade medular com auxílio de agulha tamanho 25. As medulas foram lavadas com PBS estéril e centrifugadas a $1.000 \mathrm{~g}$. As células foram ressuspensas em $2 \mathrm{ml}$ de aMEM (Gibco) contendo $10^{-7} \mathrm{M}$ prostaglandina $\mathrm{E}_{2}\left(\mathrm{PGE}_{2}\right)$ (Sigma-Aldrich), $100 \mathrm{ng} / \mathrm{ml} \mathrm{M}$ CSF (R\&D) (pH 7,4; osmolalidade $300 \mathrm{mOsm} / \mathrm{kg}$ de $\mathrm{H}_{2} \mathrm{O}$ ) contadas em câmara de Neubauer utilizando corante vital "tripan blue" e semeadas sobre plástico à densidade de $5 \times 10^{6}$ células/ml. Após incubação por 24 horas a $37{ }^{\circ} \mathrm{C} / 5 \% \mathrm{CO}_{2}$, as células não-aderentes foram coletadas, centrifugadas e ressuspensas a $4 \times 10^{5}$ células $/ \mathrm{ml}$ em $\alpha \mathrm{MEM}$, contendo prostaglandina $\mathrm{E}_{2}\left(\mathrm{PGE}_{2}\right)$ (Sigma-Aldrich) $\left(10^{-7} \mathrm{M}\right), \mathrm{M}-\mathrm{CSF}(100 \mathrm{ng} / \mathrm{ml})(\mathrm{R} \& \mathrm{D})$ e RANKL (R\&D) (10 ng/ml) (pH 7,4 ou pH 6,9; osmolalidade $300 \mathrm{mOsm} / \mathrm{kg} \mathrm{de} \mathrm{H}_{2} \mathrm{O}$ ) e semeadas sobre plástico, dentina, osso ou sobre placas de poliestireno contendo fosfato de cálcio inorgânico (Osteo Assay Surface, Corning ${ }^{\circledR}$ ) e mantidas a $37{ }^{\circ} \mathrm{C}$ e $5 \% \mathrm{CO}_{2}$ por até 7 dias. O meio de cultura foi substituído a cada 3 ou 4 dias. Os pHe 7,4 e 6,9 foram ajustados por diferentes concentrações de $\mathrm{HCO}_{3}{ }^{-}$no meio de cultura, segundo a equação de Henderson-Hasselbalch para o tampão $\mathrm{CO}_{2} / \mathrm{HCO}_{3}^{-}$.

\subsection{PRePARO E TRATAMENTO DAS SUPERFíCIES DE CULTIVO}

\subsubsection{Lamínulas de vidro e plástico}

As lamínulas de vidro foram esterilizadas por irradiação com luz ultravioleta, distribuídas em placas e banhadas com solução estéril de poli-l-lisina a 0,1\%. As placas fechadas foram transferidas para plataforma oscilante em leve agitação, onde permaneceram 
por 30 minutos. Após esse procedimento, a poli-1-lisina foi recuperada e armazenada para posterior reutilização e as placas foram lavadas com água bidestilada estéril, que foi posteriormente aspirada. As placas permaneceram abertas no fluxo laminar para evaporação da água remanescente e secagem completa das lamínulas.

As lamínulas de plástico foram distribuídas em placas, lavadas com água bidestilada estéril e esterilizadas por irradiação com luz ultravioleta.

\subsubsection{Discos de osso e dentina}

Um fragmento de fêmur bovino fresco foi coletado num açougue, os tecidos moles aderidos (periósteo, músculo e tendões) foram removidos por raspagem após imersão em água destilada por 30 minutos. A imersão e a raspagem foram repetidas até a completa remoção dos tecidos moles. A seguir, o fragmento de fêmur bovino foi imerso em peróxido de hidrogênio $\left(\mathrm{H}_{2} \mathrm{O}_{2}\right)$ por duas horas, lavado com água destilada por várias vezes e congelado em $-20{ }^{\circ} \mathrm{C}$. Esse protocolo de higienização foi obtido no Centro de Tecnologia das Radiações do Instituto de Pesquisas Energéticas e Nucleares (IPEN), responsável pela radioesterilização de tecidos biológicos para banco de tecidos, especialmente o Banco de Tecidos do Hospital das Clínicas da Faculdade de Medicina da USP. Após a higienização do osso como descrito acima, o fêmur foi cortado transversalmente em fatias de $1 \mathrm{~mm}$ de espessura, de modo que foram obtidos discos constituídos por osso cortical, já que a cavidade medular fora perdida na higienização e descontaminação. Os cortes do fêmur foram feitos em equipamento especialmente destinado a essa finalidade, no Laboratório de Tecidos Mineralizados do Setor de Microscopia e Ultraestrutura do Departamento de Anatomia do Instituto de Ciências Biomédicas da USP. Após os cortes de $1 \mathrm{~mm}$ de espessura, discos menores de osso cortical de $5 \mathrm{~mm}$ de diâmetro foram feitos com brocas destinadas especialmente ao preparo do tecido ósseo para receber implantes odontológicos osseointegráveis. Os discos foram confeccionados com o acoplamento das brocas a equipamento odontológico em baixa rotação. Os discos foram lavados três vezes com Tween 20 , a $0,05 \%$, diluído em água bidestilada. $\mathrm{O}$ tamanho dos discos (5 mm) e sua rigidez permitiram seu uso em placas de cultivo com 96 poços.

Os discos de dentina, provenientes de marfim, gentilmente cedidos pelo Dr. Timothy Arnett (Professor of Mineralised Tissue Biology, University College of London, UK), foram 
esterilizados por imersão em etanol a 70\%, secos ao ar e lavados com PBS estéril, segundo protocolo fornecido pelo Dr. Arnett.

Antes de os discos de osso ou dentina serem semeados com a suspensão celular, foram umidificados com meio de cultura e mantidos na incubadora a $37{ }^{\circ} \mathrm{C}$ e $5 \% \mathrm{CO}_{2}$ por 30 minutos.

\subsection{DROGAS INIBIDORAS DOS TRANSPORTADORES DE PRÓTONS}

Bafilomicina A1 (Tocris), inibidor da $\mathrm{H}^{+}$ATPase, foi diluída em DMSO (dimetilsulfóxido) (Sigma-Aldrich) à concentração de $30 \mu \mathrm{M}$ e utilizada nos experimentos à concentração final de $200 \mathrm{nM}$ (Nordström et al., 1995). NPPB [ácido 5Nitro-2-(3-fenilpropilamino) benzóico] (Tocris), inibidor de canais para cloreto, foi diluído em DMSO (Sigma-Aldrich) à concentração de $80 \mathrm{mM}$ e utilizado à concentração final de $100 \mu \mathrm{M}$ (Okamoto et al., 2004). $\mathrm{ZnCl}_{2}$ (Sigma-Aldrich), inibidor dos canais para prótons dependentes de voltagem, foi diluído em meio de cultura $\alpha$-MEM à concentração de $100 \mathrm{mM}$ e utilizado à concentração final de $100 \mu \mathrm{M}$ (Nordström et al., 1995). A concanamicina (Sigma-Alrich) foi utilizada à concentração de $100 \mathrm{mM}$.

\subsection{IDENTIFICAÇÃO DOS OSTEOCLASTOS DIFERENCIADOS IN VIVO}

\subsubsection{Morfológica}

Para os experimentos de $\mathrm{pHi}$, os osteoclastos foram escolhidos com base em sua morfologia, utilizando-se sistema óptico de contraste de fase em aumento de $20 \mathrm{X}$ (microscópio Olympus IX70), já que são células com a característica peculiar de possuir vários núcleos. 


\subsubsection{Imunofuorescência para o receptor de calcitonina (CTR)}

Com o objetivo de determinar a eficácia da identificação morfológica, após alguns experimentos, foram realizadas análises por imunofluorescência com anticorpo específico contra o receptor de calcitonina $(A b c a m \AA)$, proteína de membrana de osteoclastos que não está presente em outras células multinucleadas, tais como macrófagos (Arnett, Henderson, 1998).

As células foram retiradas do meio de cultura e lavadas brevemente em PBS. As amostras foram então fixadas por acetona por 1-10 minutos e posteriormente lavadas duas vezes em PBS gelado. Posteriormente, foram incubadas em PBS com 1\% de albumina bovina e $2 \%$ de gelatina por 30 minutos para bloqueio de ligações inespecíficas, e incubadas com o anticorpo policlonal de coelho para o receptor de calcitonina (diluído a 1:2.000) em PBS contendo $1 \%$ de albumina bovina por 15 horas em ambiente umidificado, a $4^{\circ} \mathrm{C}$. Após esse período, as células foram lavadas três vezes em PBS, por 5 minutos em cada lavagem e incubadas com o anticorpo secundário de cabra conjugado com FITC (isotiocianato de fluoresceína) (Abcam $\left.{ }^{\circledR}\right)$ diluído a 1:2.000 em PBS contendo 1\% de albumina bovina por 1 hora, no escuro. As células foram então lavadas três vezes em PBS, por 5 minutos em cada lavagem, e analisadas por microscopia confocal (Zeiss LSM510). A excitação das amostras foi feita por laser de argônio, com comprimento de onda de $488 \mathrm{~nm}$.

\subsection{CARACTERIZAÇÃO E QUANTIFICAÇÃO DOS OSTEOCLASTOS DIFERENCIADOS IN VITRO}

\subsubsection{Citoquímica para fosfatase ácida resistente a tartarato (TRAP)}

Os osteoclastos diferenciados in vitro foram identificados por citoquímica para a TRAP, utilizando-se kit da Sigma-Aldrich. O procedimento da Sigma-Aldrich para demonstrar a presença da enzima utiliza ácido fosfórico naftol AS-BI fosfato e granada permanente GBC diazotada em estado fresco, que se acopla rapidamente em pH ácido, formando depósitos de coloração altamente insolúveis. As células são então tratadas com solução contendo L(+)-tartarato. O naftol AS-BI, libertado pela hidrólise enzimática, acopla- 
se imediatamente à granada permanente GBC formando depósitos insolúveis de coloração castanha-avermelhada nos locais de atividade. As células que contêm fosfatase ácida sensível ao ácido tartárico são desprovidas de atividade. As células mononucleares e multinucleares contendo fosfatase resistente ao ácido tartárico não são afetadas por esse tratamento.

As amostras foram fotogradas em microscópio invertido em aumento de $20 \mathrm{X}$ e as células TRAP+ foram quantificadas com auxílio do software Image ProPlus (Figura 20).

Figura 20 - As células TRAP+ foram contadas com o software Image ProPlus.

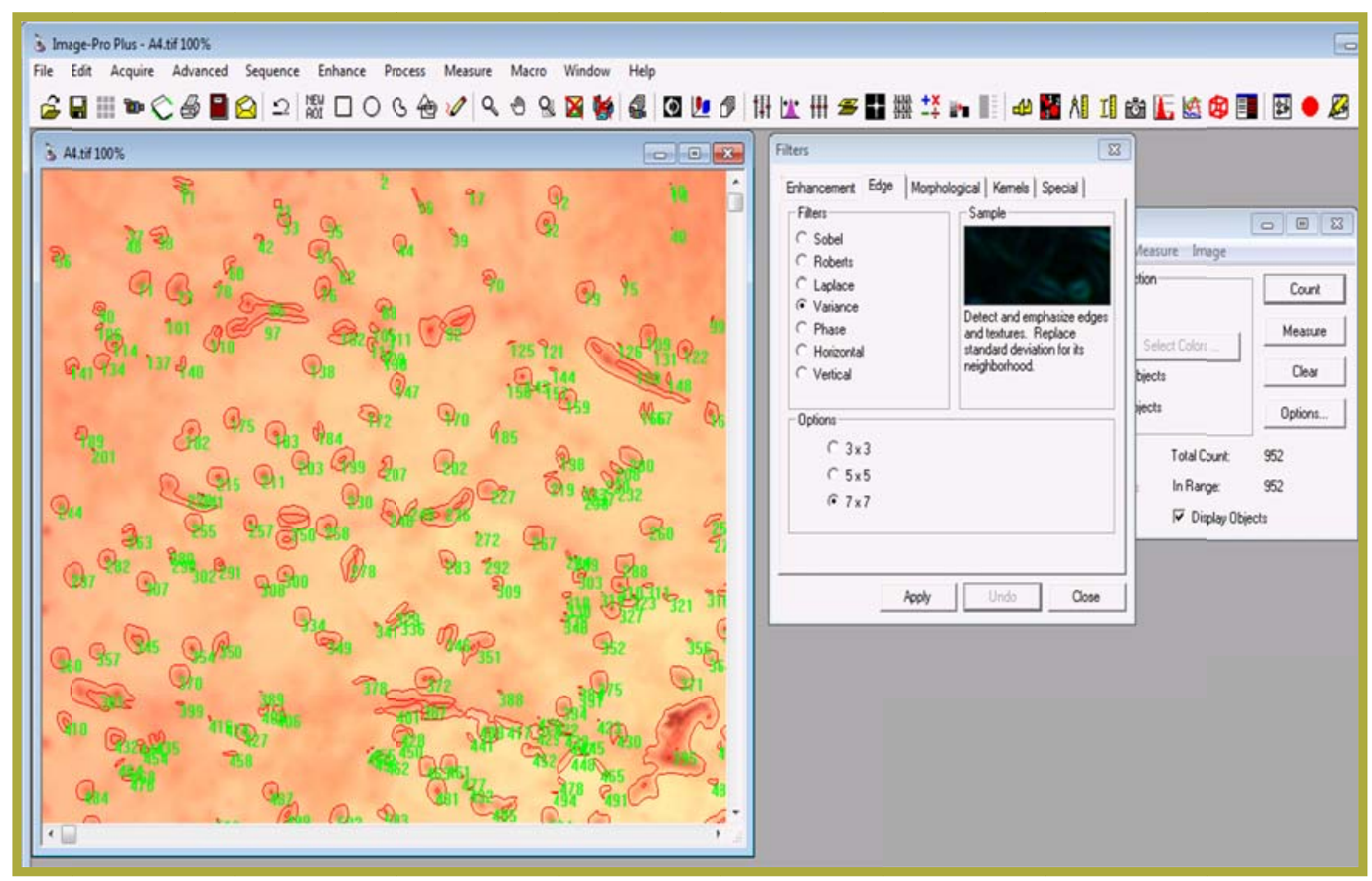

\subsubsection{Evidenciação de núcleos por DAPI}

A contagem de núcleos individualizados foi utilizada como parâmetro para determinar o tamanho dos osteoclastos diferenciados in vitro. Após a imunofluorescência, as amostras foram incubadas com DAPI (4'-6-diamidino-2-fenilindol) (1:5.000 em PBS) por 10 minutos a temperatura ambiente. O DAPI forma complexos fluorescentes quando conjugado ao DNA. As células foram então lavadas três vezes em PBS, por 5 minutos em cada lavagem, e analisadas por microscopia de fluorescência (Zeiss LSM510), com excitação das amostras por 
lâmpada HBO, com filtro para $360 \mathrm{~nm}$. As amostras foram fotografadas e os núcleos quantificados com auxílio do software Image ProPlus.

\subsubsection{Imunolocalização dos canais para $\mathrm{H}^{+}$dependentes de voltagem}

As células foram retiradas do meio de cultura e lavadas brevemente em PBS. As amostras foram então fixadas por acetona por 1-10 minutos e posteriormente lavadas duas vezes em PBS gelado. Posteriormente, foram incubadas PBS com 1\% de albumina bovina e 2\% de gelatina por 30 minutos para bloqueio de ligações inespecíficas, e incubadas com o anticorpo policlonal de coelho para o canal para prótons dependentes de voltagem $\left(\right.$ Abcam $\left.{ }^{\circledR}\right)$ diluído a 1:100, em PBS contendo 1\% de albumina bovina por 15 horas em ambiente umidificado, a $4^{\circ} \mathrm{C}$. Após esse período, as células foram lavadas três vezes em PBS, por 5 minutos em cada lavagem e incubadas com o anticorpo secundário de cabra conjugado com FITC diluído a 1:2.000 em PBS contendo 1\% de albumina bovina por 1 hora, no escuro. As células foram então lavadas três vezes em PBS, por 5 minutos em cada lavagem, e analisadas por microscopia confocal. A excitação das amostras foi feita por laser de argônio, com comprimento de onda de $488 \mathrm{~nm}$.

\subsubsection{Ensaio de reabsorção}

Osteoclastos diferenciados in vitro são considerados funcionais quando possuem capacidade de reabsorver substratos mineralizados. Com o objetivo de verificar a formação de escavações nos discos de osso ou dentina em que os osteoclastos foram diferenciados, as células foram removidas dos discos por sonicação por 10 minutos em solução de $0,2 \mathrm{M}$ $\mathrm{NH}_{4} \mathrm{OH}$ (hidróxio de amônio). Os discos foram então corados em solução de $0,1 \%$ de azul de toluidina em $1 \%$ de borato de sódio por 2 minutos, secos ao ar e analisados em microscópio óptico em aumento de 20 X, segundo descrito por Hoebertz e Arnett (2003). 


\subsubsection{Eletroforese de proteínas, detecção de CLC7 e do canal para $H^{+}$dependente de voltagem por anticorpos}

Proteínas extraídas de células aderentes no sexto dia de diferenciação na presença de RANKL foram coletadas para verificação da expressão das proteínas CLC7 e dos canais para prótons dependentes de voltagem. As proteínas foram aplicadas em gel de poliacrilamida a 10\% contendo SDS (detergente aniônico dodecil sulfato de sódio), em paralelo com um marcador de peso molecular. A eletroforese foi efetuada em cuba de eletroforese (HOEFE SE 600) a $14 \mathrm{~mA}$ por 15 horas. Após a eletroforese em gel de poliacrilamida-SDS, as proteínas contidas no gel foram transferidas para uma membrana de nitrocelulose previamente tratada com metanol $100 \%$ durante 1 minuto. Para a transferência, foi utilizado um sistema "tipo sanduíche", submerso em tampão de transferência. A transferência foi efetuada em cuba de transferência (HOEFE TE 62) a $500 \mathrm{~mA}$ por 1 hora a $4{ }^{\circ} \mathrm{C}$. Após a transferência, as posições correspondentes aos padrões de peso molecular foram marcadas para posterior identificação do peso molecular das proteínas estudadas. A membrana contendo as proteínas transferidas foi incubada em uma solução de bloqueio por 1-2 horas para impedir ligações inespecíficas de anticorpos. Em seguida, as membranas foram incubadas por 12 horas a $4{ }^{\circ} \mathrm{C}$ com os anticorpos anti-CLC7 (1:1.000) ou anti-HVCN1 (canal para próton) (1:300). As membranas foram então incubadas por 1 hora com o anticorpo secundário de cabra conjugado com HRP (horseradish peroxidase) (Abcam $\left.{ }^{\circledR}\right)(1: 2.000)$. Os anticorpos ligados foram detectados com "ECL-enhanced chemiluminescence" kit (Amersham Biosciences) por 2 minutos a temperatura ambiente. Em seguida, as membranas foram expostas a um filme X-OMAT hyperfilm (Kodak) por 5 minutos e então reveladas manualmente com a utilização de revelador e fixador para filmes de raio $\mathrm{X}$.

\subsection{MEDIDAS DE PHI POR FLUORESCÊNCIA DE BCECF}

As medidas de pHi foram realizadas nos osteoclastos cultivados sobre lamínulas de vidro tratadas com poli-lisina ou sobre plástico, por meio de microscopia de fluorescência (microscópio Olympus IX70, aumento 20 X), utilizando-se a sonda intracelular fluorescente 
sensível a pH, 2'-7'-biscarboxietil-5',6'-carboxifluoresceína (BCECF) (Molecular Probes) (Figura 21), conforme descrito por Ravesloot et al. (1995).

A forma não fluorescente do BCECF (BCECF-AM ou BCECF-acetoxi-metil ester) é lipossolúvel e atravessa facilmente a membrana celular. Uma vez no interior das células, por ação das esterases intracelulares, perde seu resíduo acetoximetil (AM), transformando-se num composto hidrossolúvel e altamente fluorescente na dependência do pHi (BCECF). O marcador passa a ser sensível a pequenas mudanças do pHi devido, principalmente, a presença do grupo $\mathrm{OH}$ fenólico e dos grupos carboxílicos carregados negativamente na sua estrutura (Bevensee et al., 2000).

Figura 21 - Estrutura química do BCECF e sua reação com $\mathrm{H}^{+}$.

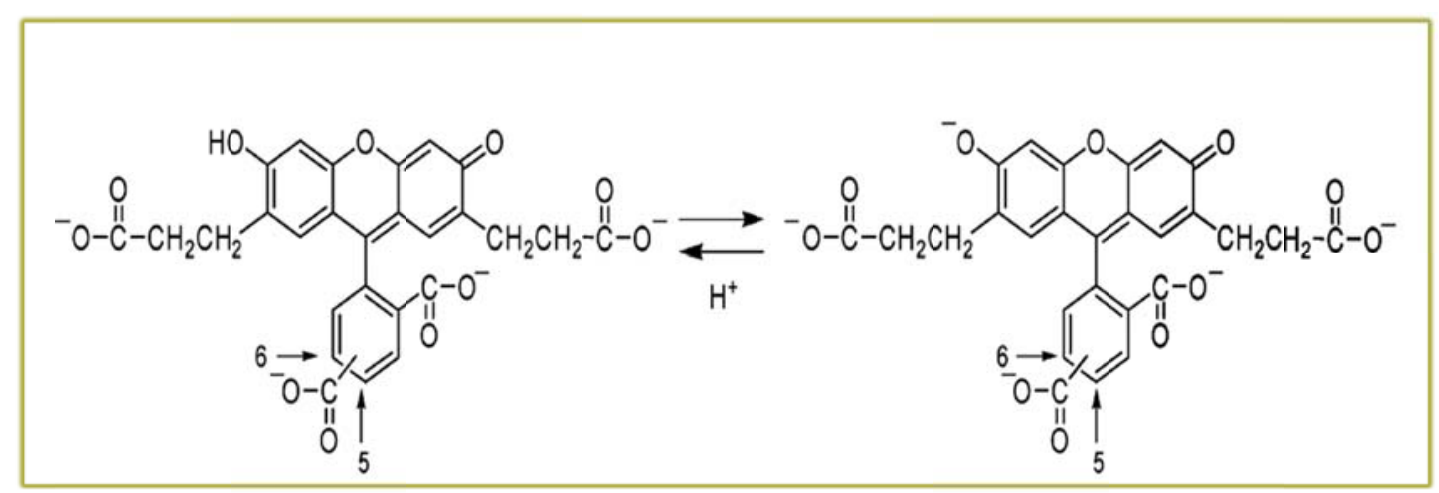

FONTE: Boens et al., 2006.

Os osteoclastos foram incubados com $12 \mu \mathrm{M}$ BCECF em solução controle por 10 a 30 minutos, a $37^{\circ} \mathrm{C}$. Após o período de incubação, as células foram lavadas com solução controle, para remover o excesso de BCECF-AM. Em seguida, a lamínula contendo os osteoclastos foi transferida para o interior de uma câmara de acrílico termorreguladora instalada sobre a platina de um microscópio de fluorescência invertido (microscópio Olympus IX70, aumento $20 \mathrm{X}$ ). Em todos os experimentos, a câmara foi mantida a $37^{\circ} \mathrm{C}$.

Para avaliar a secreção de $\mathrm{H}^{+}$, os osteoclastos foram submetidos a um pulso ácido por exposição a solução de $\mathrm{NH}_{4} \mathrm{Cl}$ a $20 \mathrm{mM}$ por 1-2 minutos, conforme descrito por Boron e De Weer (1976) (Figura 22). Durante esse período, observa-se uma alcalinização transitória do pHi devida a entrada de $\mathrm{NH}_{3}$ (amônia) na célula, que ao reagir com o $\mathrm{H}^{+}$intracelular, forma o íon $\mathrm{NH}_{4}^{+}$(amônio) de acordo com a reação:

$$
\mathrm{NH}_{3}+\mathrm{H}^{+} \leftrightarrow \mathrm{NH}_{4}^{+}
$$


Secundariamente, ocorre entrada de $\mathrm{NH}_{4}{ }^{+}$(via mecanismos de transportes para o $\mathrm{K}^{+}$ ou $\mathrm{H}^{+}$na membrana da célula) e observa-se uma lenta acidificação intracelular porque o $\mathrm{NH}_{4}^{+}$ dentro da célula se dissocia formando $\mathrm{NH}_{3}$ e $\mathrm{H}^{+}$. Após a remoção da solução de $\mathrm{NH}_{4} \mathrm{Cl}$ e subsequente perfusão da solução controle, ocorre uma abrupta acidificação do pHi devido à dissociação do $\mathrm{NH}_{4}{ }^{+}$intracelular em $\mathrm{NH}_{3}$ e $\mathrm{H}^{+}$, com posterior saída de $\mathrm{NH}_{3}$, deixando a célula carregada com o $\mathrm{H}^{+}$(Figura 22).

Figura 22 - A exposição a $\mathrm{NH}_{4} \mathrm{Cl}$ a $20 \mathrm{mM}$ causa influxo de $\mathrm{NH}_{3}$ para a célula e reação deste com o $\mathrm{H}^{+}$ intracelular, formando $\mathrm{NH}_{4}{ }^{+}$, o que eleva o pHi até que o equilíbrio entre e entrada e a saída de $\mathrm{NH}_{3}$ seja atingido (A e B). Secundariamente, ocorre influxo de $\mathrm{NH}_{4}{ }^{+}$(C) e lenta acidificação celular. Após a remoção da solução contendo $\mathrm{NH}_{4} \mathrm{Cl}$, ocorre abrupta acidificação intracelular (D) por dissociação do $\mathrm{NH}_{4}{ }^{+}$intracelular em $\mathrm{H}^{+}$e $\mathrm{NH}_{3}$ e saída de $\mathrm{NH}_{3}$.

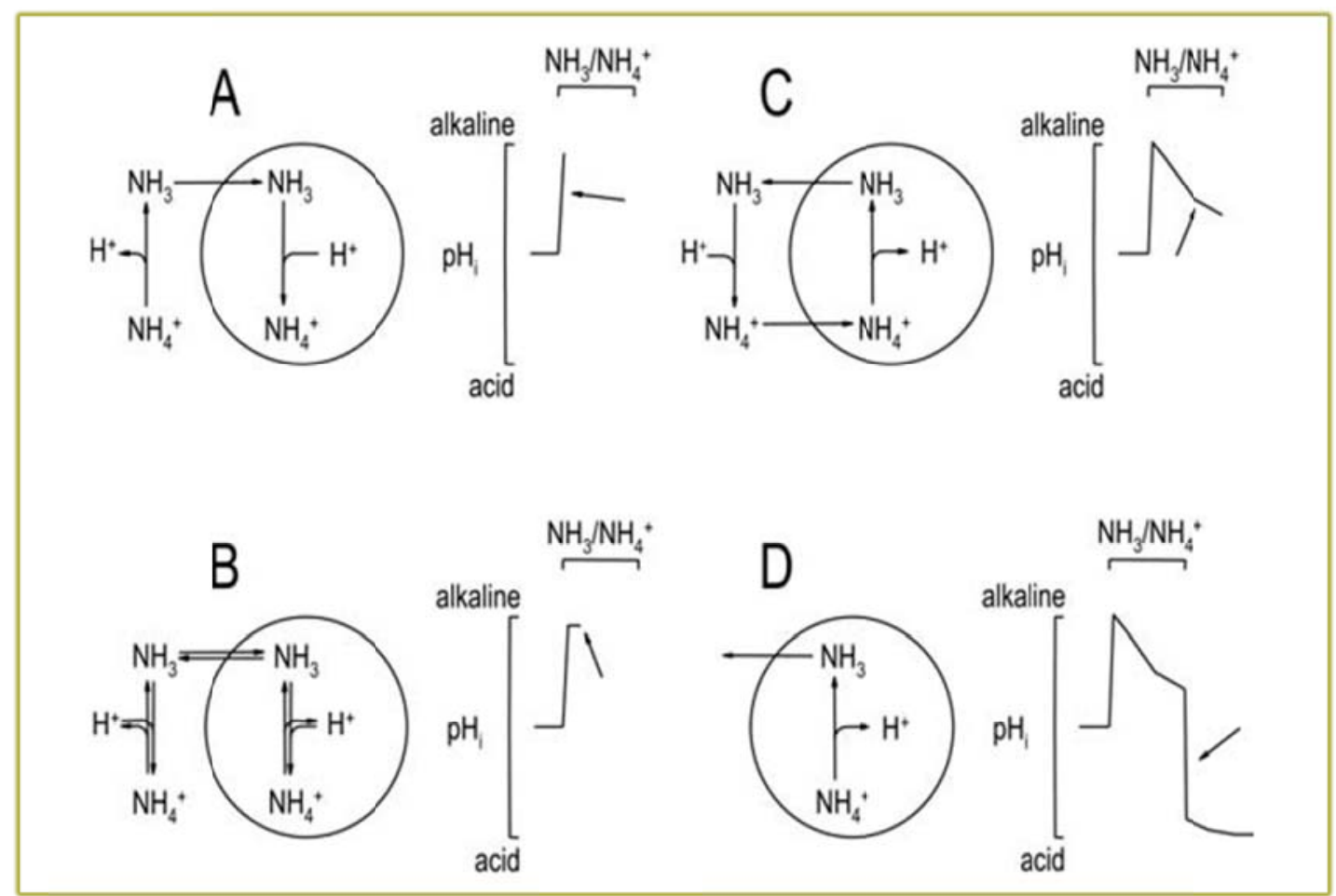

FONTE: Boron, De Weer, 1976.

Após a acidificação intracelular induzida por $\mathrm{NH}_{4} \mathrm{Cl}$, a velocidade de secreção de $\mathrm{H}^{+}$ foi expressa pelo valor do coeficiente angular da regressão linear $(\mathrm{dpHi} / \mathrm{dt})$ dos valores de $\mathrm{pHi}$ nos dois primeiros minutos.

O pHi dos osteoclastos também foi monitorado na ausência de acidificação intracelular induzida, por períodos que variaram de minutos a horas. Tanto nestes experimentos quanto naqueles com acidificação induzida, foram avaliados os efeitos dos 
inibidores dos transportadores de prótons dos osteoclastos e o efeito da presença ou ausência de fluxo de fluido (perfusão) sobre a secreção de $\mathrm{H}^{+}$e a regulação do pHi.

O controle do início e da parada da perfusão e a troca das soluções experimentais foram realizados remotamente com auxílio de um de um sistema controlador de fluxo (Warner Instruments). A perfusão foi aplicada em uma única direção à velocidade de 5 $\mathrm{ml} /$ minuto, e foi mantida constante por meio do controlador de fluxo.

Todos os experimentos de pHi foram feitos na ausência de $\mathrm{NaHCO}_{3}$, com o intuito de não estimular a atividade dos mecanismos carregadores de base, como por exemplo, o cotransportador $\mathrm{Na}^{+}-\mathrm{HCO}_{3}{ }^{-}$. As soluções experimentais continham concentrações de eletrólitos semelhantes às fisiologicamente presentes no plasma e tiveram a osmolalidade ajustada em $300 \mathrm{mOsm} / \mathrm{kg}$ de $\mathrm{H}_{2} \mathrm{O}$. Sua composição encontra-se na Tabela 1. Os tampões utilizados foram HEPES e fosfato, em $\mathrm{pH} 7,4$. A temperatura das soluções experimentais foi mantida a $37{ }^{\circ} \mathrm{C}$, na presença ou ausência de perfusão. Nos experimentos na ausência de $\mathrm{Na}^{+}$ ou $\mathrm{Cl}^{-}$extracelular, a solução controle (descrita na Tabela 1) foi modificada. $\mathrm{O} \mathrm{Na}^{+}$foi substituído por N-methyl-d-glucamine (NMDG $138 \mathrm{mM}$ ). A solução sem $\mathrm{Cl}^{-}$foi composta por: $\mathrm{C}_{6} \mathrm{H}_{11} \mathrm{NaO}_{7} 134 \mathrm{mM}, \mathrm{C}_{6} \mathrm{H}_{11} \mathrm{KO}_{7} 5 \mathrm{mM}, \mathrm{CaHPO}_{4} .2 \mathrm{H}_{2} \mathrm{O} 2 \mathrm{mM}, \mathrm{MgSO}_{4} 1 \mathrm{mM}$, $\mathrm{C}_{8} \mathrm{H}_{18} \mathrm{~N}_{2} \mathrm{SO}_{4} 20 \mathrm{mM}, \mathrm{NaOH} 8 \mathrm{mM}, \mathrm{C}_{6} \mathrm{H}_{12} \mathrm{O}_{6} 5,5 \mathrm{mM}$.

Tabela 1 - Composição das soluções utilizadas nos experimentos com osteoclastos. As concentrações dos reagentes foram expressas em mM. A osmolalidade das soluções era de $300 \mathrm{mOsm} / \mathrm{Kg} \mathrm{de} \mathrm{H}_{2} \mathrm{O}$.

\begin{tabular}{|c|c|c|c|c|}
\hline Reagentes & Controle & $\mathrm{NH}_{4} \mathrm{Cl}$ & BCECF & Nigericina \\
\hline $\mathrm{NaCl}$ & 138 & 140 & 138 & 20 \\
\hline $\mathrm{KCl}$ & 5 & 5 & 5 & 130 \\
\hline $\mathrm{CaCl}_{2}$ & 1,8 & 1,8 & 1,8 & 1 \\
\hline $\mathrm{MgCl}_{2}$ & - & - & - & 1 \\
\hline $\mathrm{MgSO}_{4}$ & 0,81 & 0,81 & 0,81 & - \\
\hline $\mathrm{NaH}_{2} \mathrm{PO}_{4}$ & 0,9 & 0,9 & 0,9 & - \\
\hline HEPES & 10 & 10 & 10 & 5 \\
\hline Glicose & 5 & 5 & 5 & - \\
\hline $\mathrm{NaOH}$ & 8 & 8 & 8 & - \\
\hline $\mathrm{NH}_{4} \mathrm{Cl}$ & - & 20 & - & - \\
\hline Nigericina & - & - & - & 0,01 \\
\hline $\mathrm{NaHCO}_{3}$ & - & - & - & - \\
\hline BCECF & - & - & 0,01 & - \\
\hline pH (solução) & 7,4 & 8,0 & 7,4 & $8,0-5,0$ \\
\hline
\end{tabular}




\subsubsection{Microscopia de fluorescência}

Os osteoclastos foram identificados visualmente e então delimitados com auxílio do software MetaFluor (Molecular Devices). A fluorescência emitida pelos osteoclastos delimitados (contendo BCECF em seu interior) foi registrada continuamente durante os experimentos. Foram utilizados dois comprimentos de onda para a excitação do BCECF: $440 \mathrm{~nm}$ e $490 \mathrm{~nm}$. A fluorescência emitida após excitação a $440 \mathrm{~nm}$, o ponto isosbéstico do $\mathrm{BCECF}$, não depende de $\mathrm{pH}$. Dessa maneira, o cálculo da razão entre a fluorescência emitida após as excitações a 490 e a $440 \mathrm{~nm}(\mathrm{R}=\mathrm{I} 490 / \mathrm{I} 440)$ elimina erros decorrentes de eventuais perdas do fluoróforo, e tem amplitude proporcional ao pHi. O sistema para aquisição da fluorescência está ilustrado na Figura 23.

Figura 23 - No microscópio de fluorescência (Olympus IX70), a luz é proveniente de uma lâmpada de Xenônio e conduzida por fibras ópticas até uma roda de filtros de interferência para os comprimentos de onda $440 \mathrm{~nm}$ e $490 \mathrm{~nm}$. A passagem da luz para os filtros é controlada remotamente por um dispositivo de abertura e fechamento rápidos (“shutter"). A luz é conduzida até um espelho dicroico, que reflete os comprimentos de onda selecionados que excitam a amostra após passagem pela objetiva do microscópio. A fluorescência emitida acima do comprimento de corte do espelho dicróico $(\lambda \mathrm{c}=510$ $\mathrm{nm})$ é coletada por uma câmera e registrada pelo computador.

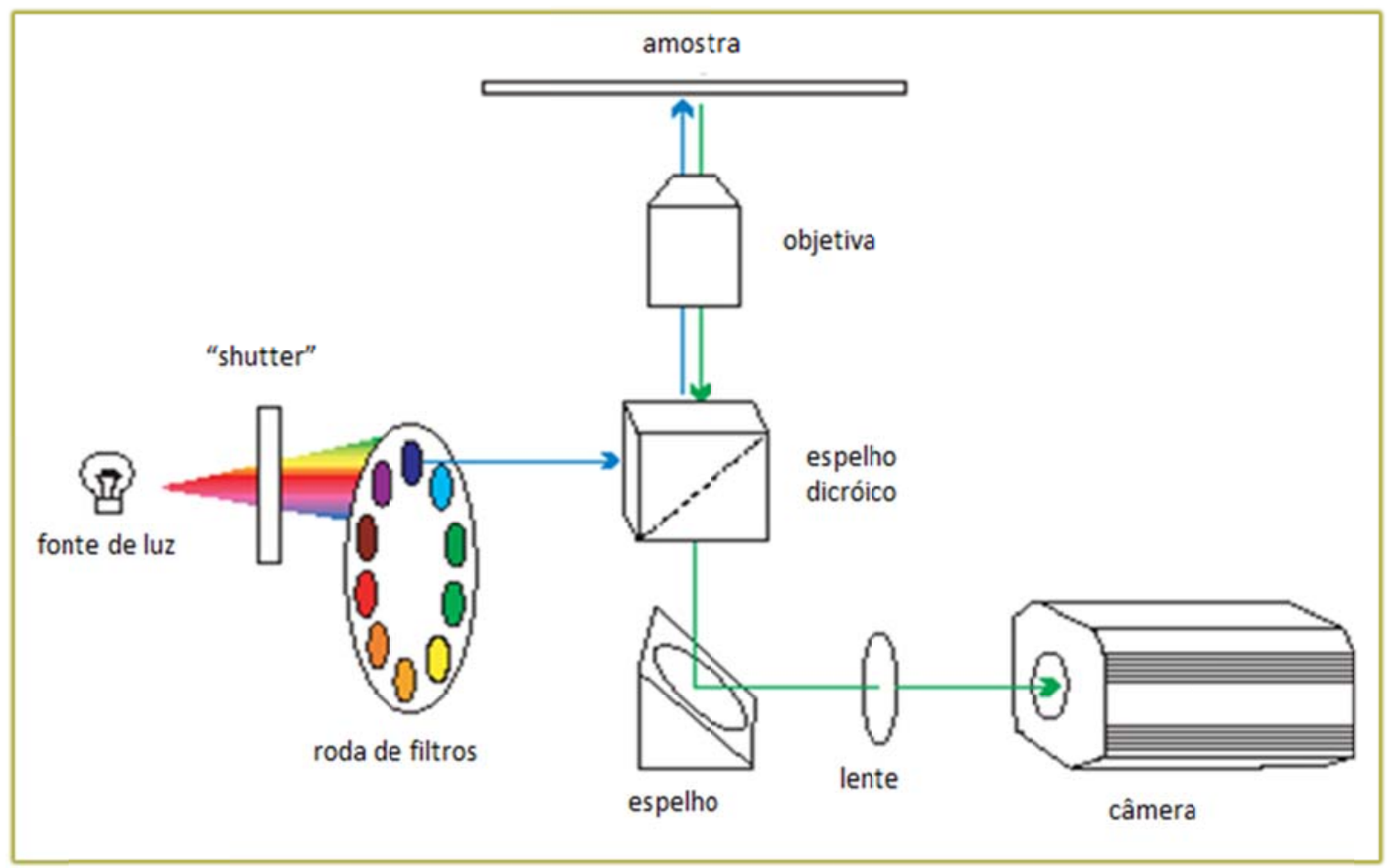




\subsubsection{Curva de calibração}

O pHi foi calculado utilizando-se a técnica de calibração da nigericina (Invitrogen) em solução com alta concentração de $\mathrm{K}^{+}(110 \mathrm{mM})$. A nigericina é um ionóforo carboxílico capaz de trocar o $\mathrm{K}^{+}$por $\mathrm{H}^{+}$através de membranas celulares. À medida que a $\left[\mathrm{K}^{+}\right]$extracelular é igualada à $\left[\mathrm{K}^{+}\right]$intracelular, o $\mathrm{pH}_{\mathrm{i}}$ deve se igualar ao $\mathrm{pHe}$. Alterando-se o $\mathrm{pHe}$ para um valor conhecido, na presença da nigericina, podemos medir valores de fluorescência correspondentes aos valores de $\mathrm{pH}_{\mathrm{i}}$. Nos experimentos de calibração, os osteoclastos foram expostos a soluções de calibração contendo $10 \mu \mathrm{M}$ de nigericina e ajustadas a diferentes valores de $\mathrm{pH}$ (entre 8,0 e 5,0), incluindo-se o $\mathrm{pH}$ 7,0. Ao final de cada experimento de monitoramento do $\mathrm{pHi}$, com ou sem indução de acidificação intracelular por $\mathrm{NH}_{4} \mathrm{Cl}$, os osteoclastos foram expostos à solução contendo nigericina em $\mathrm{pH} 7,0$. Todos os registros da razão I490/I440 experimentais foram então normalizados, dividindo-se seus valores pelos valores da razão de fluorescência a pH 7,0, segundo descrito por Ravesloot et al. (1995). O procedimento para o cálculo dos valores de pHi está descrito na Figura 24.

Figura 24 - A. Razões de fluorescência a diferentes pHs em um experimento de calibração na presença de BCECF $(12 \mu \mathrm{M})$, nigericina $(10 \mu \mathrm{M})$ e alto $\mathrm{K}^{+}$extracelular $(110 \mathrm{mM})$. B. Indicação dos valores de pH utilizados nos experimentos de calibração em múltiplos pontos. Os valores médios de razão de fluorescência I490/I440 (eixo y) para cada valor de pH conhecido (eixo x) são divididos pela razão média da fluorescência a pH 7,0, o que gera uma função não-linear (C), descrita em $\mathbf{D}$. D. Exemplo de um registro de experimento de pHi com carga ácida por $\mathrm{NH}_{4} \mathrm{Cl}$ e calibração final em $\mathrm{pH} 7,0$, (indicada pela seta) em 4 diferentes células. A função descrita (obtida nos experimentos de calibração) é utilizada para o cálculo dos valores de pHi.

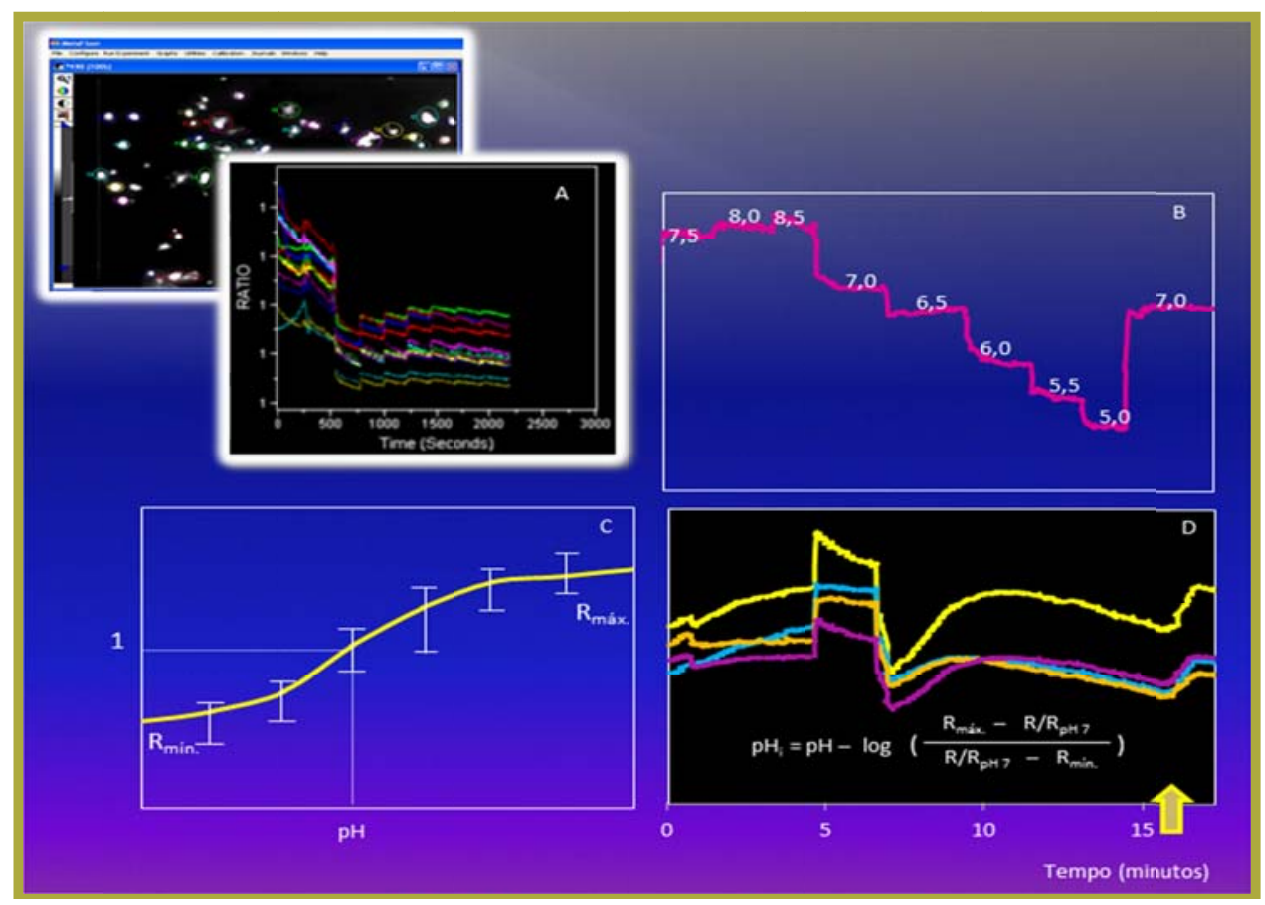




\subsection{ANÁLISE DOS RESULTADOS}

As análises estatísticas empregadas foram os testes de Mann Whitney, Spearman e Pearson, de acordo com o tipo da variável e o número de experimentos realizados. Para cada resultado apresentado como média \pm erro padrão, foram também indicados o valor de $\mathrm{p}$, o número de experimentos e o teste estatístico utilizado. Também foram realizadas análises qualitativas, segundo critérios subjetivos, e cujos resultados se apresentam como texto descritivo. 


\section{RESUlTADOS}

\subsection{IDENTIFICAÇ̃̃O DOS OSTEOCLASTOS DIFERENCIADOS IN VIVO}

A identificação morfológica dos osteoclastos diferenciados in vivo para as análises de pHi na presença de BCECF foi validada pela imunolocalização do receptor de calcitonina (Figura 25).

Figura 25 - Acima: osteoclasto diferenciado in vivo identificado por sua morfologia (tamanho e multinuclearidade). Em A, imagem de fluorescência na presença de BCECF, em $\mathbf{B}$, imagem de luz transmitida (microscópio confocal Zeiss, LSM510). Abaixo: validação do método de identificação morfológica pela imunolocalização do receptor de calcitonina. Em A, imagem da luz transmitida, em B, imagem de fluorescência (microscópio confocal Zeiss, LSM510).

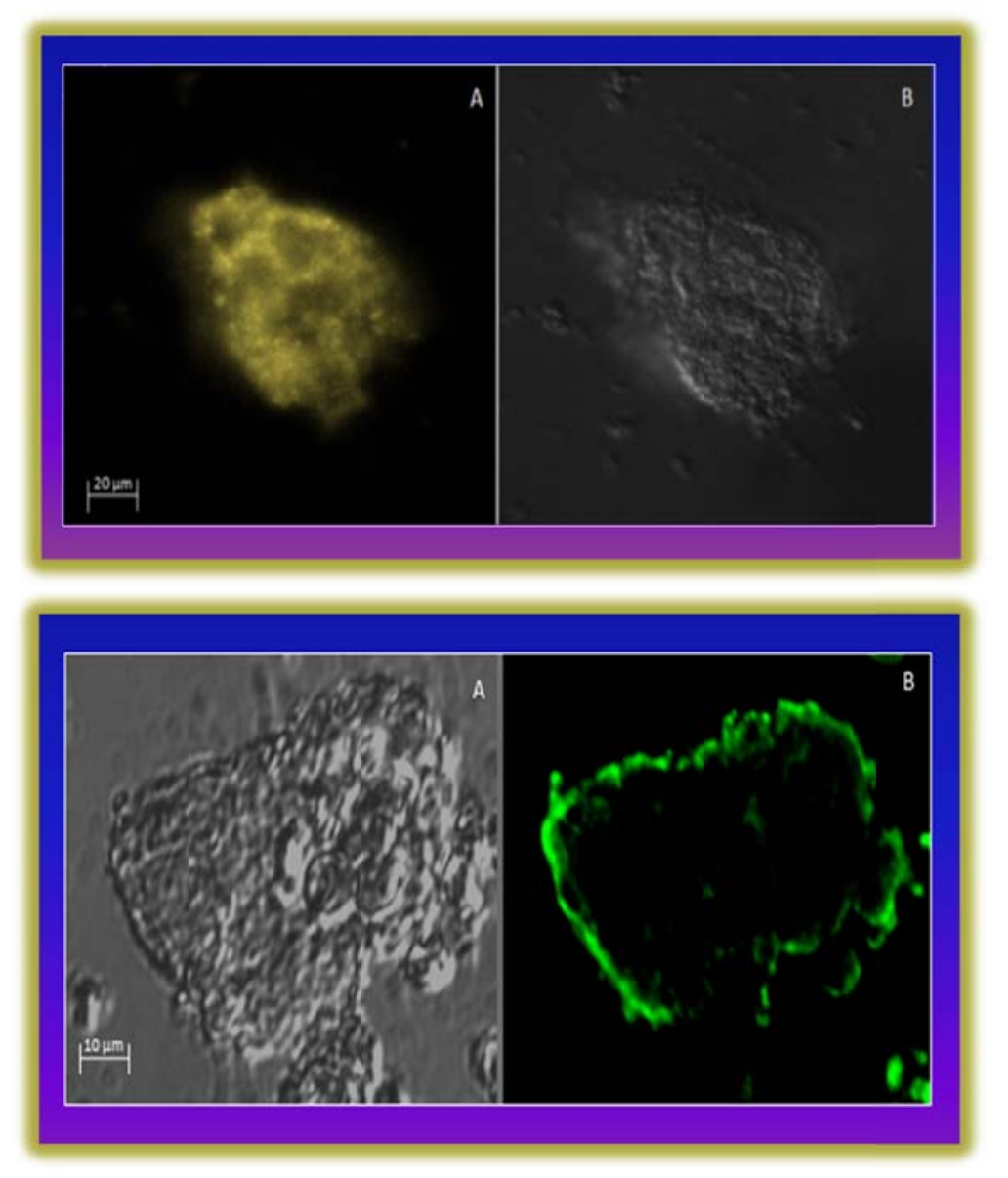




\subsection{CARACTERIZAÇÃO DOS OSTEOCLASTOS DIFERENCIADOS IN VITRO}

A diferenciação sobre plástico gerou células TRAP+ mononucleadas e multinucleadas, que expressaram o trocador CLC7 e os canais para $\mathrm{H}^{+}$dependentes de voltagem, como verificado na eletroforese seguida de imunodetecção (Figura 26). Os osteoclastos diferenciados in vitro sobre dentina ou osso demonstraram habilidade para a reabsorção de substrato mineralizado, conforme verfificado nos ensaios de reabsorção óssea (Figura 28 A). Os osteoclastos diferenciados in vitro sobre dentina expressaram os canais para $\mathrm{H}^{+}$na região imediatamente adjacente ao substrato rarefeito, indicando que os canais para $\mathrm{H}^{+}$se localizam onde ocorre secreção vetorial de $\mathrm{H}^{+}$(Figura 28 B). Os canais para $\mathrm{H}^{+}$em osteoclastos diferenciados sobre plástico ou dentina localizam-se em microdomínios da membrana imediatamente oposta ao substrato (Figuras 27 a 29).

Figura 26 - Osteoclastos diferenciados in vitro sobre plástico por citoquímica para TRAP (à esquerda) (aumento $20 \mathrm{X}$ ). A diferenciação resultou em osteoclastos mononucleados e multinucleados. Expressão do trocador $\mathrm{Cl}^{-} / \mathrm{H}^{+}$(CLC7) (ao centro) e do canal para $\mathrm{H}^{+}$dependente de voltagem (à direita) em osteoclastos diferenciados in vitro sobre plástico.
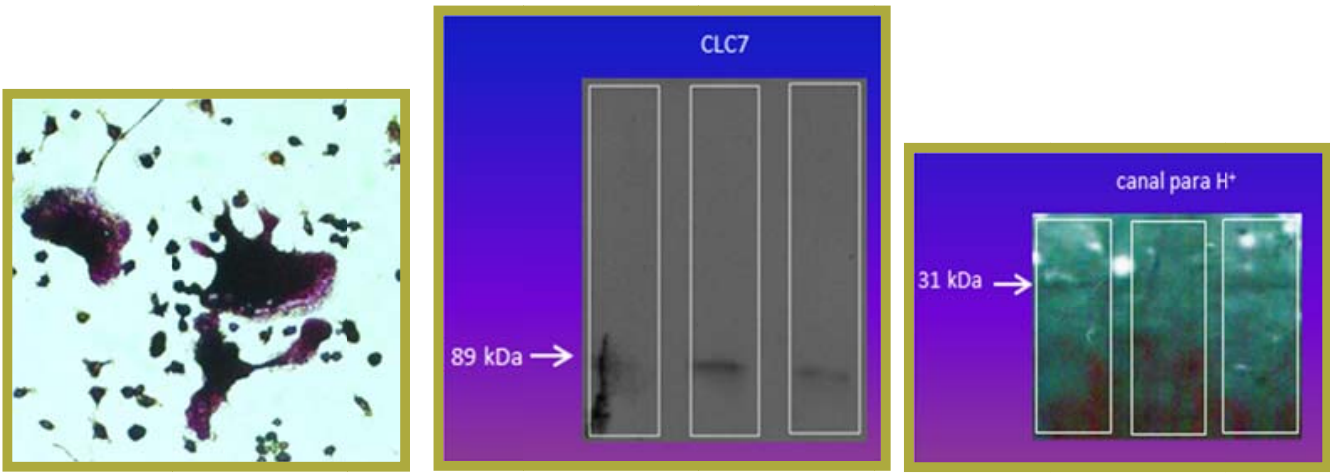

Figura 27 - Imunolocalização dos canais para $\mathrm{H}^{+}$dependentes de voltagem em osteoclastos diferenciados in vitro sobre dentina. A seta indica a concentração da fluorescência primordialmente em microdomínios na região de membrana adjacente ao substrato.

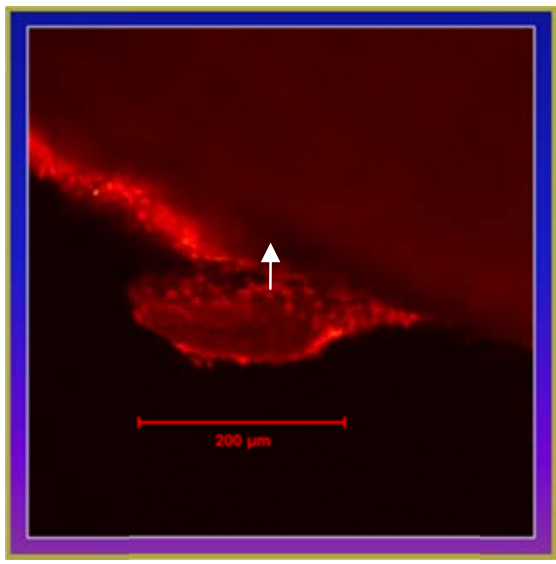


Figura 28 - A - Superfícies de osso utilizadas para a diferenciação dos osteoclastos in vitro onde foram evidenciadas as áreas reabsorvidas por azul de toluidina a $0,1 \%$ (Aumento: $10 \mathrm{X}$ e $20 \mathrm{X}$ ).

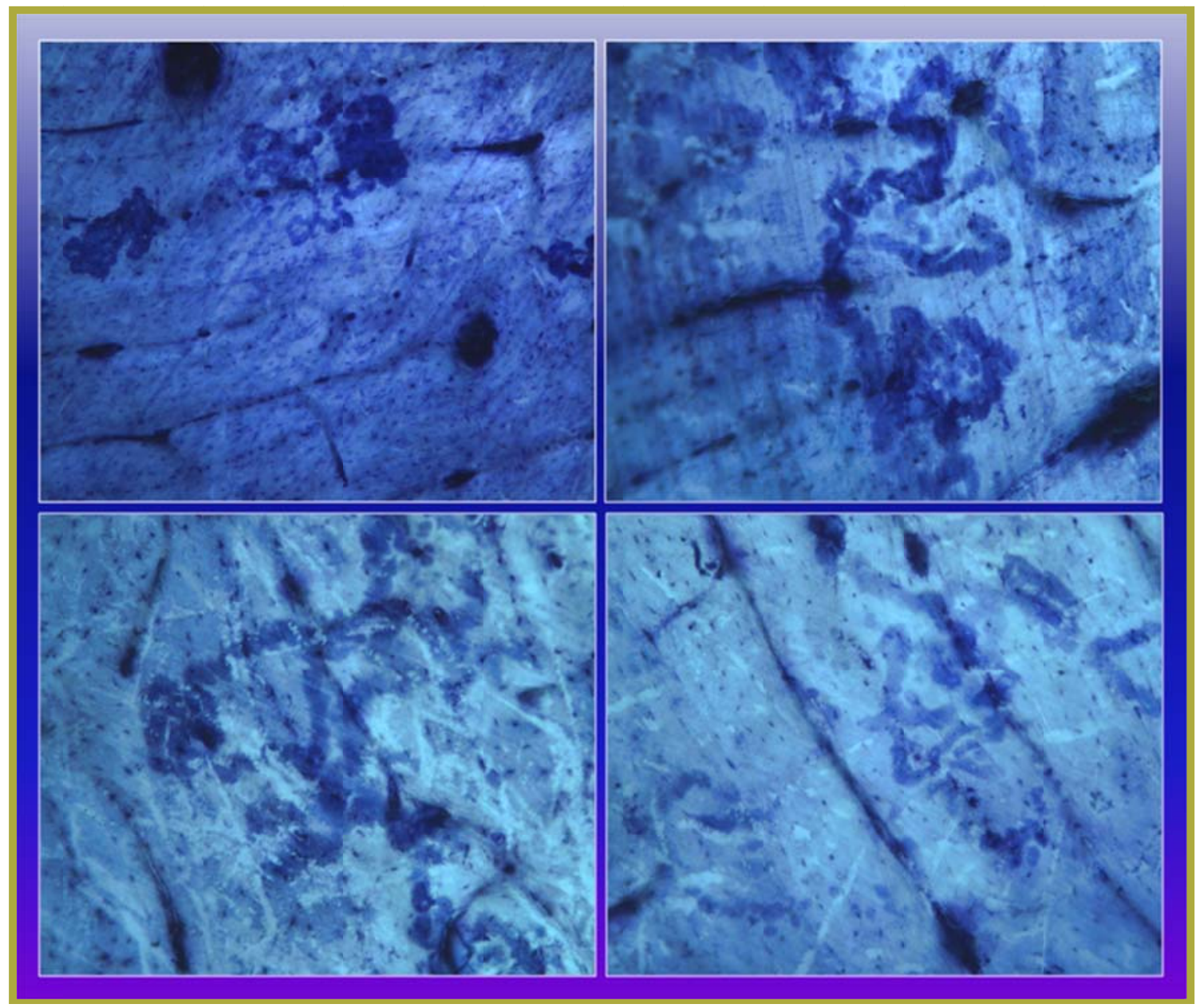


Figura 28 - B - Imunolocalização dos canais para $\mathrm{H}^{+}$dependentes de voltagem em osteoclastos diferenciados in vitro sobre dentina. As figuras de A a D são variações da coloração da imagem realizadas com auxílio do software do microcópio confocal LSM 510 (Zeiss). Em B, as setas indicam regiões de rarefação do substrato em regiões imediatamente adjacentes às regiões de membrana com maior intensidade de fluorescência. Em $\mathbf{D}$, as setas indicam a concentração da fluorescência em microdomínios de membrana na região imediatamente oposta ao substrato rarefeito, indicando que os canais para $\mathrm{H}^{+}$se localizam primordialmente na membrana pregueada, região em que ocorre a secreção vetorial de $\mathrm{H}^{+}$.

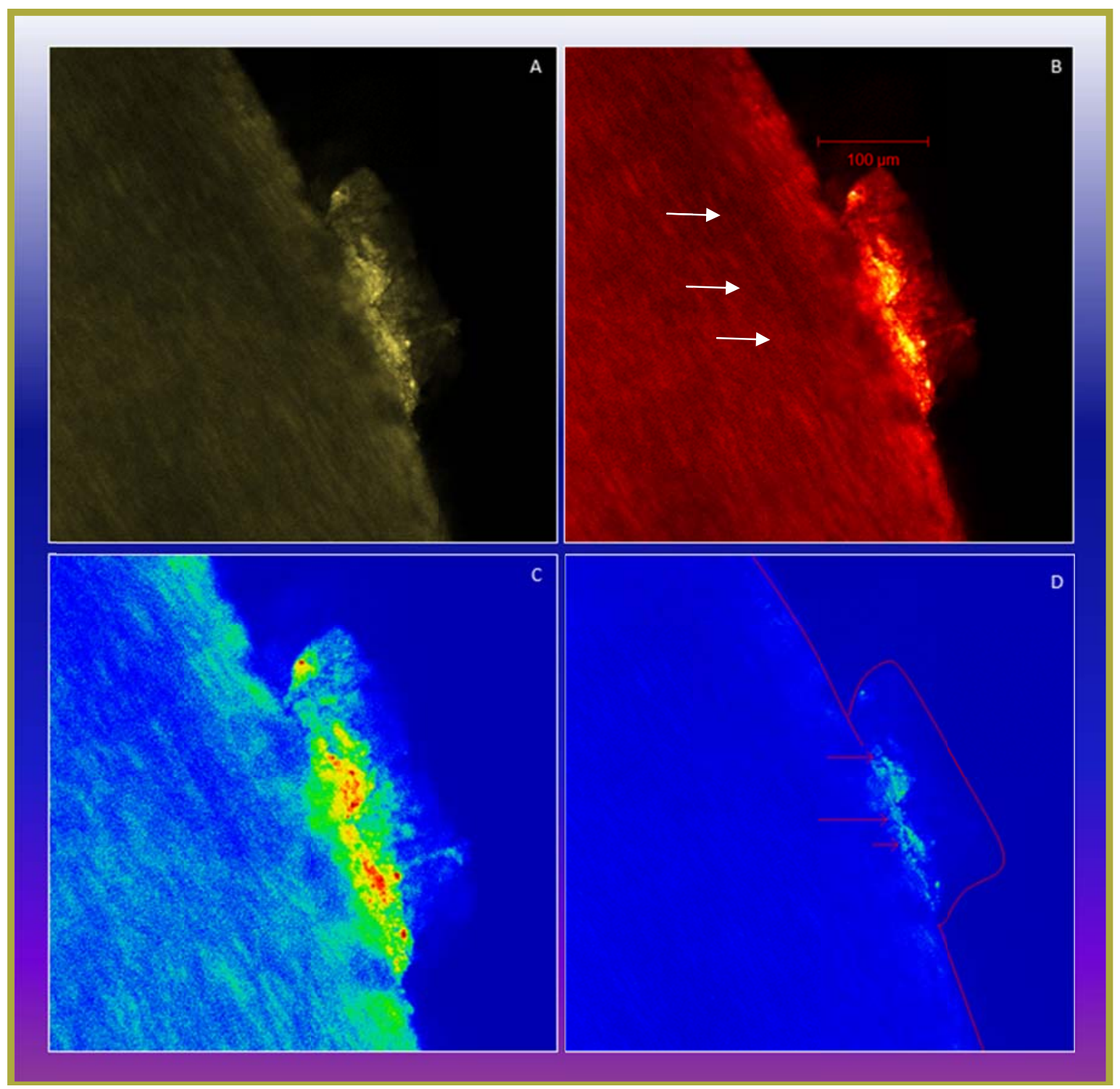


Figura 29 - Imunolocalização dos canais para $\mathrm{H}^{+}$dependentes de voltagem em osteoclastos diferenciados in vitro sobre plástico. Como observado nos osteoclastos diferenciados sobre dentina, os canais localizam-se em microdomínios de membrana em regiões imediatamente adjacentes ao substrato.

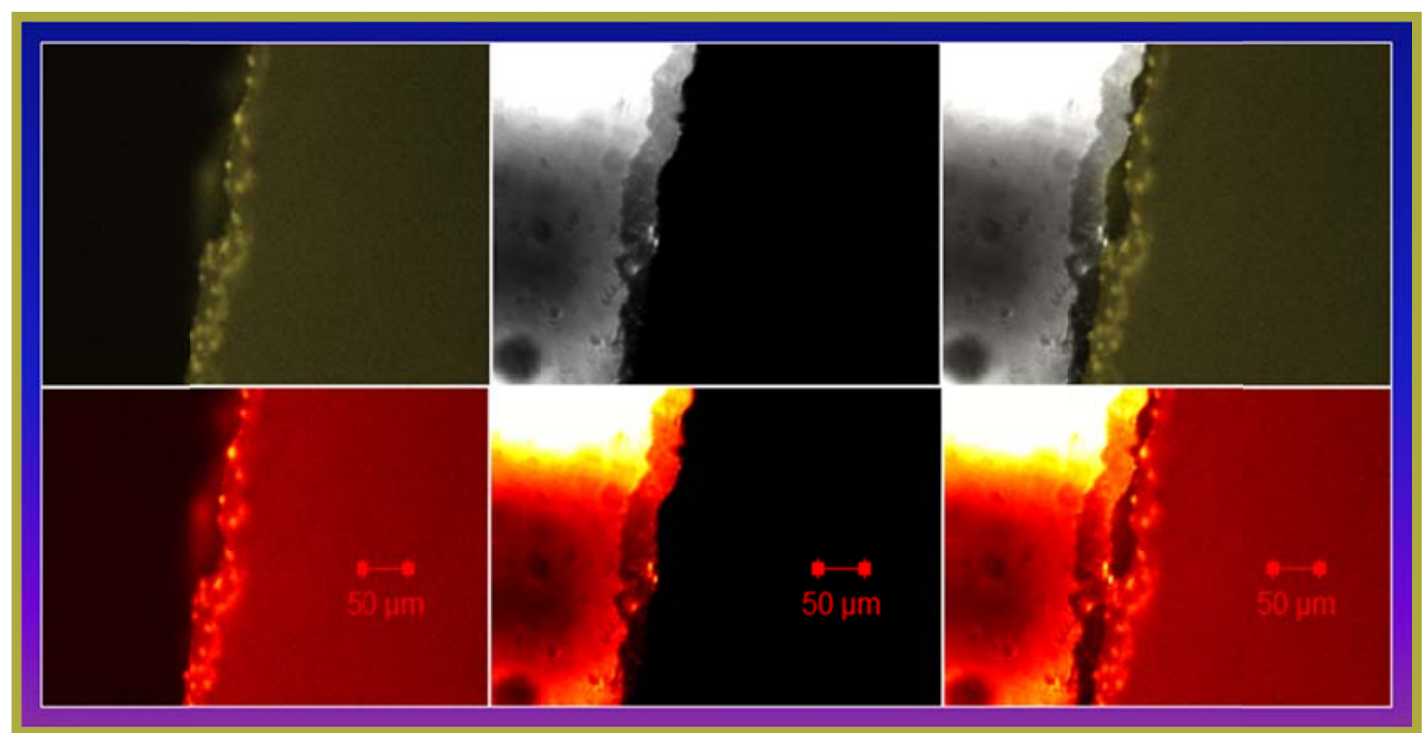

\subsection{SECREÇÃO DE $\mathrm{H}^{+}$E REGUlaÇÃO DO PHi DE OSTEOCLASTOS - EFEITOS DA ACIDIFICAÇÃO INTRACELULAR INDUZIDA E DO FLUXO DE FLUIDO EXTRACELULAR}

O pHi dos osteoclastos de ratos diferenciados in vivo não se estabiliza, tendo sido observadas alcalinização e acidificação antes da aplicação da solução contendo $\mathrm{NH}_{4} \mathrm{Cl}$ a $20 \mathrm{mM}$, o que indica alteração espontânea da secreção de $\mathrm{H}^{+}$na ausência de $\mathrm{CO}_{2} / \mathrm{HCO}_{3}{ }^{-}$, conforme ilustrado na Figura 30. Entretanto, para fins de análise comparativa, foi definido "pHi inicial" aquele apresentado imediatamente antes da alcalinização induzida por $\mathrm{NH}_{4} \mathrm{Cl}$. O pHi inicial, segundo essa definição, variou de 6,68 a 8,01 (7,35 $\pm 0,32 ; n=27)$ (Figura 30). Após acidificação intracelular induzida pela remoção do $\mathrm{NH}_{4} \mathrm{Cl}$, os osteoclastos diferenciados in vivo apresentam diferentes taxas de secreção de $\mathrm{H}^{+}$. Alguns osteoclastos exibem alta capacidade de secreção de $\mathrm{H}^{+}$após o desafio ácido, enquanto outros, em condições experimentais similares, não apresentam a mesma capacidade de secreção. $\mathrm{O}$ dpHi/dt nos dois primeiros minutos após a acidificação induzida variou de 0,01 a 0,58 unidades de $\mathrm{pH}$ por minuto $(\mathrm{n}=27)$ (Figura 31). Os resultados individuais dos experimentos de medida do $\mathrm{pHi}$ de osteoclastos diferenciados in vivo estão apresentados na Figura 32. 
Figura 30 - Registro de pHi de quatro osteoclastos de ratos diferenciados in vivo, em que se observa a instabilidade do pHi na ausência de $\mathrm{CO}_{2} / \mathrm{HCO}_{3}{ }^{-}$, antes da aplicação da solução contendo $\mathrm{NH}_{4} \mathrm{Cl}$ (seta) (à esquerda). Dispersão dos valores de pHi inicial de osteoclastos ratos diferenciados in vivo (à direita).
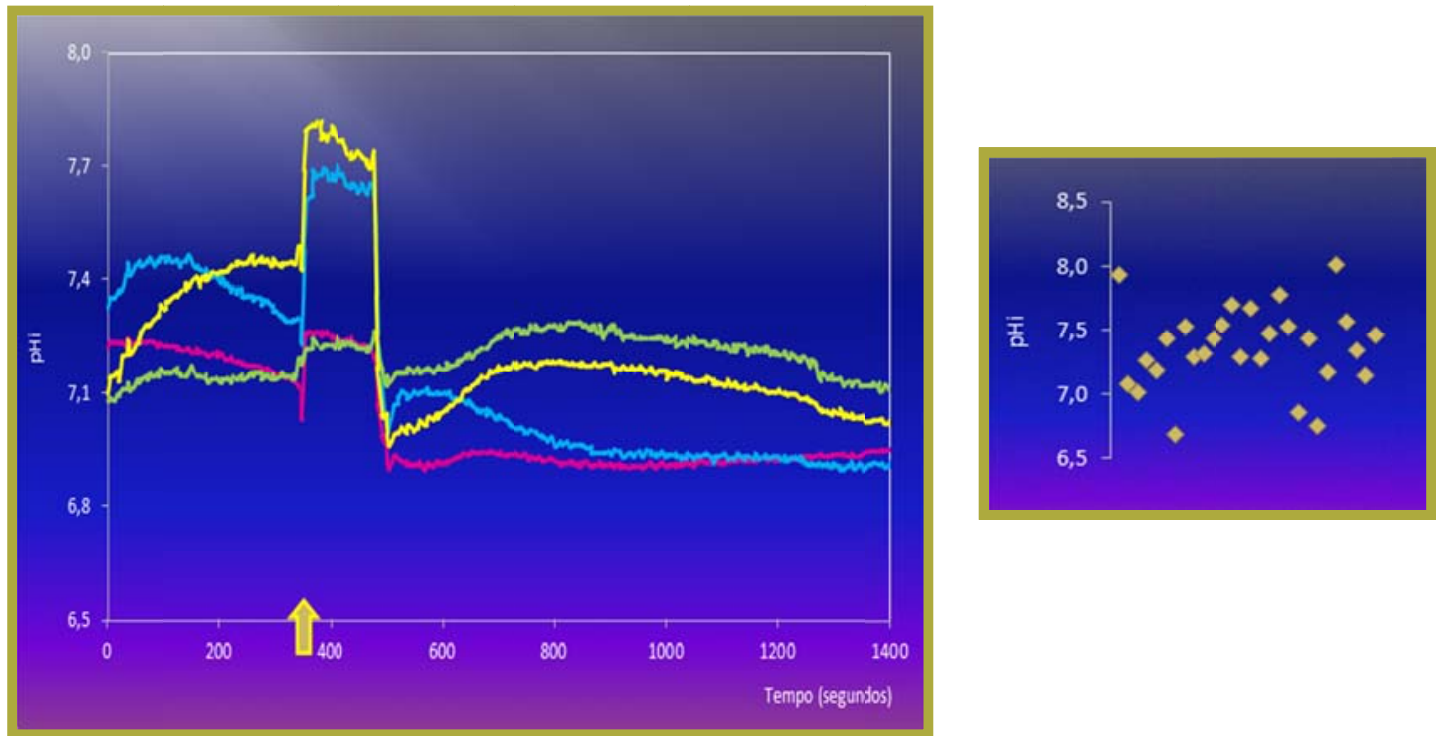

Figura 31 - Dispersão dos valores de dpHi/dt de osteoclastos diferenciados in vivo. As taxas de secreção de $\mathrm{H}^{+}$ nos dois minutos após a acidificação intracelular induzida por $\mathrm{NH}_{4} \mathrm{Cl}$ variaram de 0,01 a 0,58 unidade de $\mathrm{pH} /$ minuto $(\mathrm{n}=27)$ (acima). Abaixo, o registro da razão de fluorescência emitida (Intensity ROI 1 , em unidades arbitrárias no eixo y) por osteoclasto diferenciado in vivo submetido à acidificação intracelular induzida.
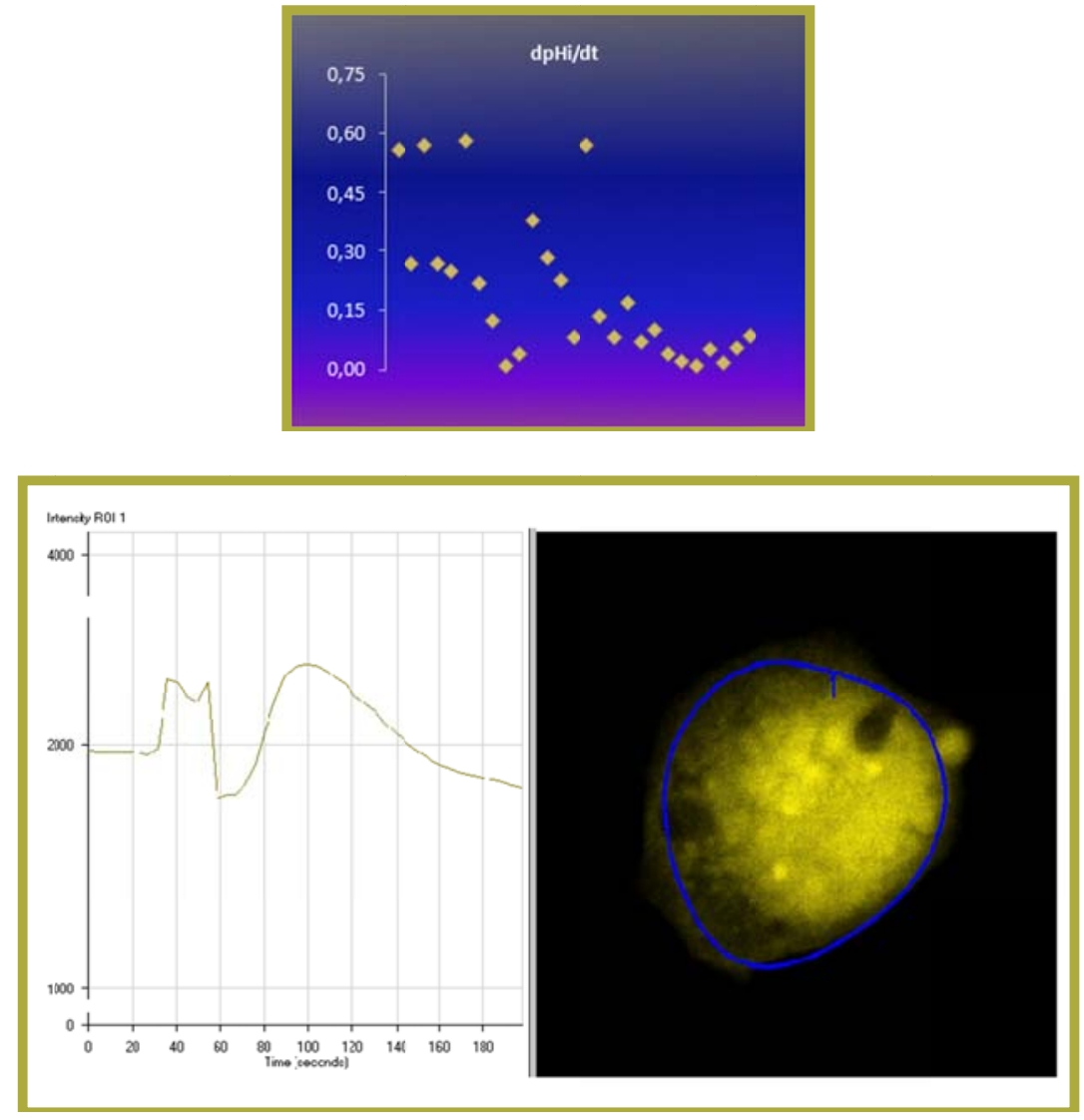
Figura 32 - Resultados dos experimentos de medida do pHi de osteoclastos diferenciados in vivo. O pH inicial corresponde ao pHi imediatamente antes da aplicação da solução com $\mathrm{NH}_{4} \mathrm{Cl}(20 \mathrm{mM})$; o pH de alcalinização corresponde ao pHi máximo registrado na presença de $\mathrm{NH}_{4} \mathrm{Cl}$; o $\mathrm{pH}$ de acidificação corresponde ao pHi mínimo após remoção do $\mathrm{NH}_{4} \mathrm{Cl}$; o dpH/dt corresponde ao coeficiente angular da regressão linear dos valores de $\mathrm{pHi}$ nos dois primeiros minutos após a máxima acidificação; o $\Delta \mathrm{pH}$ corresponde à diferença entre o $\mathrm{pH}$ extracelular $(\mathrm{pHe})$ e o intracelular $(\mathrm{pHi})$ no momento da máxima acidificação.

\begin{tabular}{|c|c|c|c|c|}
\hline pH inicial & $\begin{array}{c}\text { pH de } \\
\text { alcalinização }\end{array}$ & pH de acidificação & $\mathrm{dpH} / \mathrm{dt}$ & $\begin{array}{c}\Delta p H \\
(p H e-p H i)\end{array}$ \\
\hline 7,93 & 8,71 & 6,58 & 0,56 & 0,82 \\
\hline 7,07 & 7,51 & 6,26 & 0,27 & 1,14 \\
\hline 7,01 & 7,69 & 6,60 & 0,57 & 0,80 \\
\hline 7,26 & 7,34 & 6,43 & 0,27 & 0,97 \\
\hline 7,17 & 7,58 & 6,14 & 0,25 & 1,26 \\
\hline 7,42 & 8,34 & 6,62 & 0,58 & 0,78 \\
\hline 6,68 & 7,43 & 6,64 & 0,22 & 0,77 \\
\hline 7,52 & 8,42 & 6,64 & 0,13 & 0,76 \\
\hline 7,28 & 7,48 & 6,69 & 0,01 & 0,71 \\
\hline 7,31 & 7,59 & 6,72 & 0,04 & 0,68 \\
\hline 7,43 & 7,98 & 6,12 & 0,38 & 1,28 \\
\hline 7,53 & 7,99 & 6,70 & 0,29 & 0,71 \\
\hline 7,69 & 7,94 & 6,66 & 0,23 & 0,74 \\
\hline 7,28 & 9,13 & 6,78 & 0,08 & 0,62 \\
\hline 7,66 & 8,16 & 6,34 & 0,57 & 1,06 \\
\hline 7,27 & 7,97 & 7,31 & 0,14 & 0,10 \\
\hline 7,47 & 7,60 & 6,12 & 0,08 & 1,28 \\
\hline 7,77 & 8,00 & 6,35 & 0,17 & 1,05 \\
\hline 7,52 & 7,98 & 6,89 & 0,07 & 0,51 \\
\hline 6,85 & 7,25 & 6,37 & 0,10 & 1,03 \\
\hline 7,43 & 7,82 & 6,86 & 0,04 & 0,54 \\
\hline 6,74 & 7,29 & 6,52 & 0,02 & 0,88 \\
\hline 7,17 & 7,24 & 6,92 & 0,01 & 0,48 \\
\hline 8,01 & 9,06 & 7,16 & 0,05 & 0,24 \\
\hline 7,34 & 7,68 & 7,00 & 0,02 & 0,40 \\
\hline 7,14 & 7,22 & 7,15 & 0,05 & 0,25 \\
\hline 7,45 & 7,77 & 6,99 & 0,09 & 0,41 \\
\hline
\end{tabular}

Os valores de dpHi/dt de osteoclastos diferenciados in vivo não têm correlação com o pHi inicial, mas estão correlacionados à magnitude da acidificação, ou seja, à diferença entre o $\mathrm{pH}$ inicial e o $\mathrm{pH}$ de acidificação $(\mathrm{p}=0,0089, \mathrm{n}=27$; Pearson, "one-tailed"). Desse modo, quanto maior o grau de acidificação, maior a velocidade de secreção de $\mathrm{H}^{+}$após o desafio ácido. Os valores da magnitude de acidificação em cada osteoclasto avaliado estão apresentados na Figura 33. 
Figura 33 - Valores da magnitude da acidificação ( $\mathrm{pH}$ inicial - $\mathrm{pH}$ ácido) e dpHi/dt de osteoclastos diferenciados in vivo.

\begin{tabular}{|c|c|}
\hline pH inicial - pH ácido & $\mathrm{dpH} / \mathrm{dt}$ \\
\hline 1,35 & 0,56 \\
\hline 0,81 & 0,27 \\
\hline 0,41 & 0,57 \\
\hline 0,83 & 0,27 \\
\hline 1,03 & 0,25 \\
\hline 0,80 & 0,58 \\
\hline 0,04 & 0,22 \\
\hline 0,88 & 0,13 \\
\hline 0,59 & 0,01 \\
\hline 0,59 & 0,04 \\
\hline 1,31 & 0,38 \\
\hline 0,84 & 0,29 \\
\hline 1,03 & 0,23 \\
\hline 0,50 & 0,08 \\
\hline 1,32 & 0,57 \\
\hline$-0,04$ & 0,14 \\
\hline 1,35 & 0,08 \\
\hline 1,42 & 0,17 \\
\hline 0,63 & 0,07 \\
\hline 0,48 & 0,10 \\
\hline 0,57 & 0,04 \\
\hline 0,22 & 0,02 \\
\hline 0,24 & 0,01 \\
\hline 0,84 & 0,05 \\
\hline 0,33 & 0,02 \\
\hline$-0,01$ & 0,05 \\
\hline 0,46 & 0,09 \\
\hline
\end{tabular}

A magnitude da acidificação induzida por $\mathrm{NH}_{4} \mathrm{Cl}$ em osteoclastos diferenciados in vivo está correlacionada ao pHi inicial ( $\mathrm{p}<0,0001, \mathrm{n}=27$; Spearman, "two-tailed"). Os valores registrados para cada osteoclasto avaliado estão apresentados na Figura 34. 
Figura 34 - Valores de pH inicial (A) e valores da magnitude da acidificação $\mathrm{A}$ - B, diferença entre o pH inicial e o $\mathrm{pH}$ ácido (B), mínimo pHi induzido após a remoção do $\mathrm{NH}_{4} \mathrm{Cl}$ em osteoclastos de ratos diferenciados in vivo.

\begin{tabular}{|c|c|}
\hline pH inicial (A) & $\begin{array}{c}\text { pH inicial - pHácido } \\
(\mathbf{A}-\mathbf{B})\end{array}$ \\
\hline 7,27 & $-0,04$ \\
\hline 7,14 & $-0,01$ \\
\hline 6,68 & 0,04 \\
\hline 6,74 & 0,22 \\
\hline 7,17 & 0,24 \\
\hline 7,34 & 0,33 \\
\hline 7,01 & 0,41 \\
\hline 7,45 & 0,46 \\
\hline 6,85 & 0,48 \\
\hline 7,28 & 0,50 \\
\hline 7,43 & 0,57 \\
\hline 7,28 & 0,59 \\
\hline 7,31 & 0,59 \\
\hline 7,52 & 0,63 \\
\hline 7,42 & 0,80 \\
\hline 7,07 & 0,81 \\
\hline 7,26 & 0,83 \\
\hline 7,53 & 0,84 \\
\hline 8,01 & 0,84 \\
\hline 7,52 & 0,88 \\
\hline 7,17 & 1,03 \\
\hline 7,69 & 1,03 \\
\hline 7,43 & 1,31 \\
\hline 7,66 & 1,32 \\
\hline 7,93 & 1,35 \\
\hline 7,47 & 1,35 \\
\hline 7,77 & 1,42 \\
\hline
\end{tabular}

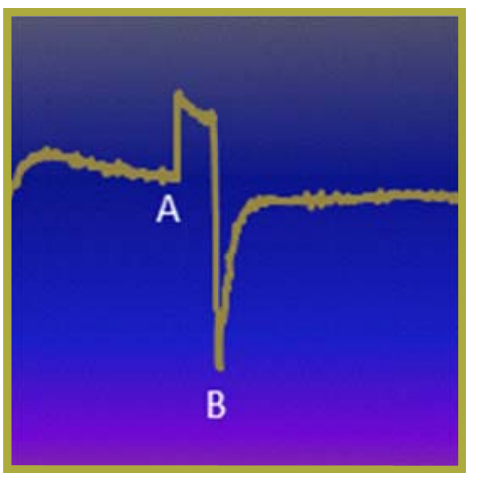

Adicionalmente, há correlação entre a taxa de secreção de $\mathrm{H}^{+}(\mathrm{dpHi} / \mathrm{dt})$ e $\Delta \mathrm{pH}, \mathrm{o}$ gradiente entre o pH extracelular e o pH intracelular no momento da máxima acidificação $(\mathrm{p}=0,0036, \mathrm{n}=27$; Spearman, "two-tailed"). Os valores registrados para cada osteoclasto diferenciado in vivo avaliado estão apresentados na Figura 35. 
Figura 35 - Valores da taxa de secreção de $\mathrm{H}^{+}(\mathrm{dpH} / \mathrm{dt})$ e dos correspondentes gradientes de $\mathrm{pH}-\Delta \mathrm{pH}-$, diferença entre o $\mathrm{pH}$ extracelular $(\mathrm{pHe})$ e o $\mathrm{pH}$ intracelular ( $\mathrm{pHi}$ ), no momento da máxima acidificação induzida por $\mathrm{NH}_{4} \mathrm{Cl}$ em osteoclastos de ratos diferenciados in vivo.

\begin{tabular}{|c|c|}
\hline $\mathrm{dpH} / \mathrm{dt}$ & $\Delta p H(p H e-p H i)$ \\
\hline 0,14 & 0,10 \\
\hline 0,05 & 0,24 \\
\hline 0,05 & 0,25 \\
\hline 0,02 & 0,40 \\
\hline 0,09 & 0,41 \\
\hline 0,01 & 0,48 \\
\hline 0,07 & 0,51 \\
\hline 0,04 & 0,54 \\
\hline 0,08 & 0,62 \\
\hline 0,04 & 0,68 \\
\hline 0,29 & 0,71 \\
\hline 0,01 & 0,71 \\
\hline 0,23 & 0,74 \\
\hline 0,13 & 0,76 \\
\hline 0,22 & 0,77 \\
\hline 0,58 & 0,78 \\
\hline 0,57 & 0,80 \\
\hline 0,56 & 0,82 \\
\hline 0,02 & 0,88 \\
\hline 0,27 & 0,97 \\
\hline 0,10 & 1,03 \\
\hline 0,17 & 1,05 \\
\hline 0,57 & 1,06 \\
\hline 0,27 & 1,14 \\
\hline 0,25 & 1,26 \\
\hline 0,38 & 1,28 \\
\hline 0,08 & 1,28 \\
\hline
\end{tabular}

Em registros de experimentos realizados por períodos superiores a 20 minutos, na presença ou na ausência de acidificação induzida por $\mathrm{NH}_{4} \mathrm{Cl}$, na ausência de perfusão, foram observadas alterações cíclicas do pHi de osteoclastos diferenciados in vivo e in vitro. As oscilações do pHi registradas em ambas as condições caracterizam-se por períodos de alcalinização e acidificação espontâneas alternados de modo temporalmente regular, como 
demonstrado na Figura 36. As oscilações do pHi são independentes da perda do fluoróforo, como se observa na Figura 37.

Figura 36 - Registros das razões de fluorescência (I490/I440) em três amostras diferentes. Na parte superior da imagem, observam-se as oscilações espontâneas da I490/I440 (à esquerda) de um osteoclasto diferenciado in vivo selecionado (destaque em vermelho) com auxílio do software MetaFluor (à direita). Abaixo, vê-se o registro da I490/I440 de um tecido vegetal autofluorescente (Convallaria) em que foram aplicados os mesmos parâmetros de iluminação que os utilizados para o osteoclasto destacado; observa-se que a I490/I440 emitida pelo tecido vegetal permanece constante ao longo do tempo. À direita, na parte inferior da imagem, vê-se o registro da I490/I440 de células imortalizadas de túbulo proximal renal (LLCPK1) previamente incubadas com BCECF, em que foram aplicados os mesmos parâmetros de iluminação e o mesmo procedimento de incubação com BCECF utilizados para o osteoclasto destacado; observa-se que a I490/I440 emitida pelo tecido vegetal permanece constante ao longo do tempo.

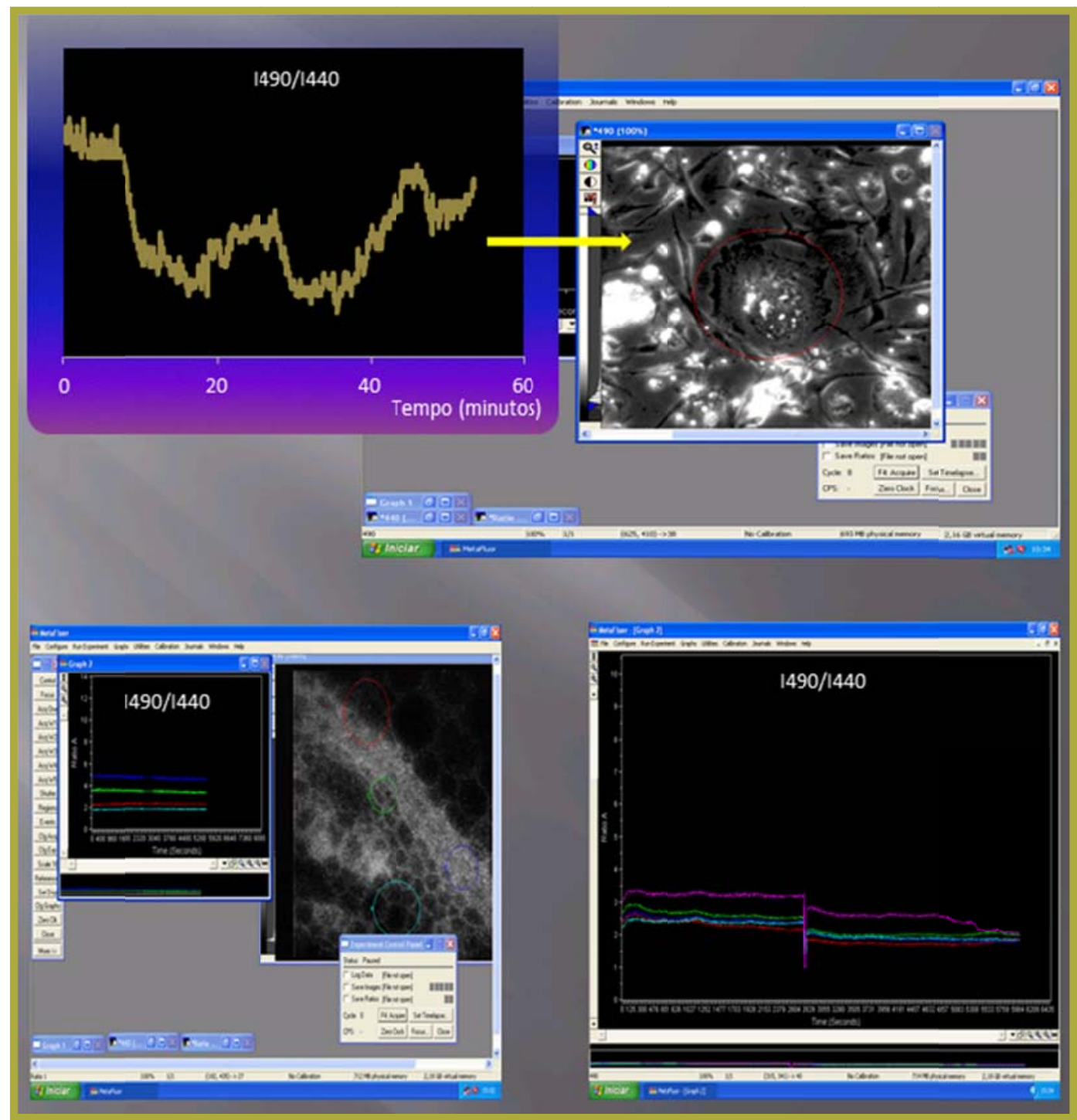


Figura 37 - Registro de pHi de osteoclastos diferenciados in vivo. A fluorescência emitida a $440 \mathrm{~nm}$ (I440) e $490 \mathrm{~nm}$ (I490) é representada no eixo y em unidades arbitrárias. A I490 depende de pHi e exibe oscilações durante o período de registro. A I440 depende da concentração de BCECF e não depende de $\mathrm{pH}$. Nota-se que não há perda significativa do fluoróforo durante o período do registro. $\mathrm{O}$ intervalo entre uma excitação a $490 \mathrm{~nm}$ e outra a $440 \mathrm{~nm}$ é de 5 milisegundos, tempo suficientemente curto para garantir que haja correspondência entre as emissões após as excitações nos dois comprimentos de onda. Este experimento foi iniciado com perfusão à velocidade de $5 \mathrm{ml} / \mathrm{min}$; a seta indica o momento de parada da perfusão.

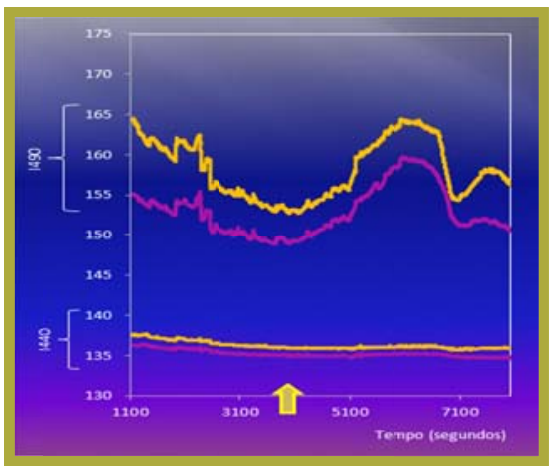

As oscilações de pHi foram observadas em $92 \%$ dos experimentos com osteoclastos diferenciados in vivo, na ausência de perfusão. Na ausência ou na presença de acidificação induzida por $\mathrm{NH}_{4} \mathrm{Cl}$ e na ausência de perfusão, foram observados diferentes padrões de oscilação do pHi de osteoclastos diferenciados in vivo, como se observa na Figura 38. O período, ou seja, o intervalo de tempo compreendido entre um pico e outro (entre dois valores máximos de pHi) variou de 12 a 45 minutos $(\mathrm{n}=35)$. A amplitude das oscilações, diferença entre o pHi máximo e mínimo, variou de 0,12 a 1,43 unidades de $\mathrm{pH}$.

Figura 38 - Registro de pHi de osteoclastos diferenciados in vivo. Foram observados diferentes padrões de oscilação do pHi. No traçado em amarelo, observa-se a oscilação após acidificação intracelular induzida.

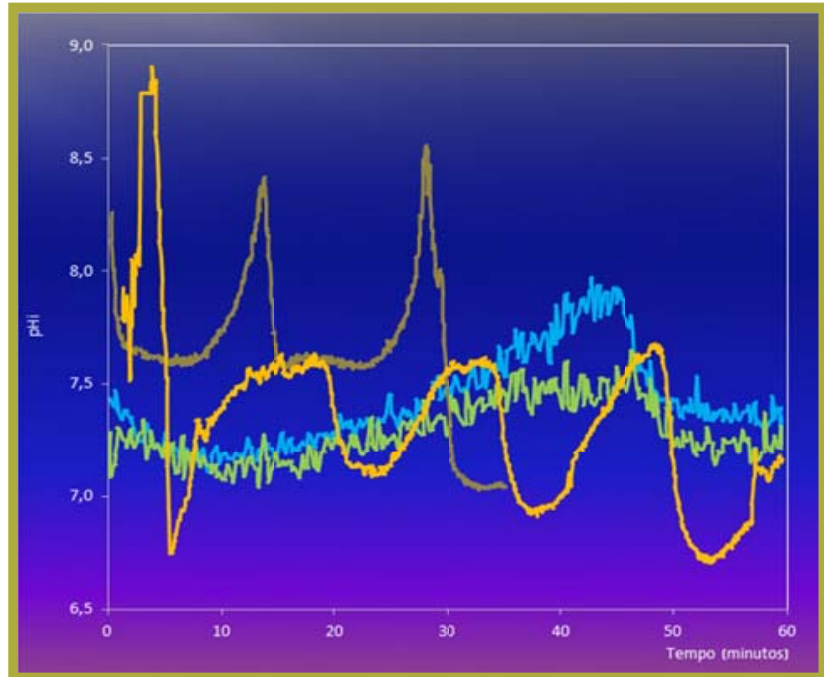


Em um experimento, as oscilações do pHi foram registradas até a morte celular, o que ocorreu no período de 3,6 horas, possivelmente pela modificação da osmolalidade da solução, já que nesse período pode ocorrer evaporação significativa de solvente, com consequente concentração de solutos. O registro deste experimento está ilustrado na Figura 39.

As oscilações do pHi não foram abolidas por concanamicina (inibidor da $\mathrm{H}^{+}$ATPase) $(\mathrm{n}=3)$, por NPPB (inibidor de canais para cloreto) $(\mathrm{n}=3)$, por ausência de $\mathrm{Na}^{+}$ extracelular $(\mathrm{n}=5)$ ou por ausência de $\mathrm{Cl}^{-}$extracelular $(\mathrm{n}=3)$ (Figura 40). Na ausência de $\mathrm{Cl}^{-}$extracelular houve modificação do padrão das oscilações do pHi de osteoclastos diferenciados in vivo $(\mathrm{n}=3)$, conforme ilustrado na Figura 41.

Figura 39 - Registro de pHi de osteoclastos diferenciados in vivo. As oscilações do pHi de dois osteoclastos foram registradas por um período de 3,6 horas. Ao final do registro, foi observada queda abrupta da razão de fluorescência (I490/I440) devido à morte celular.

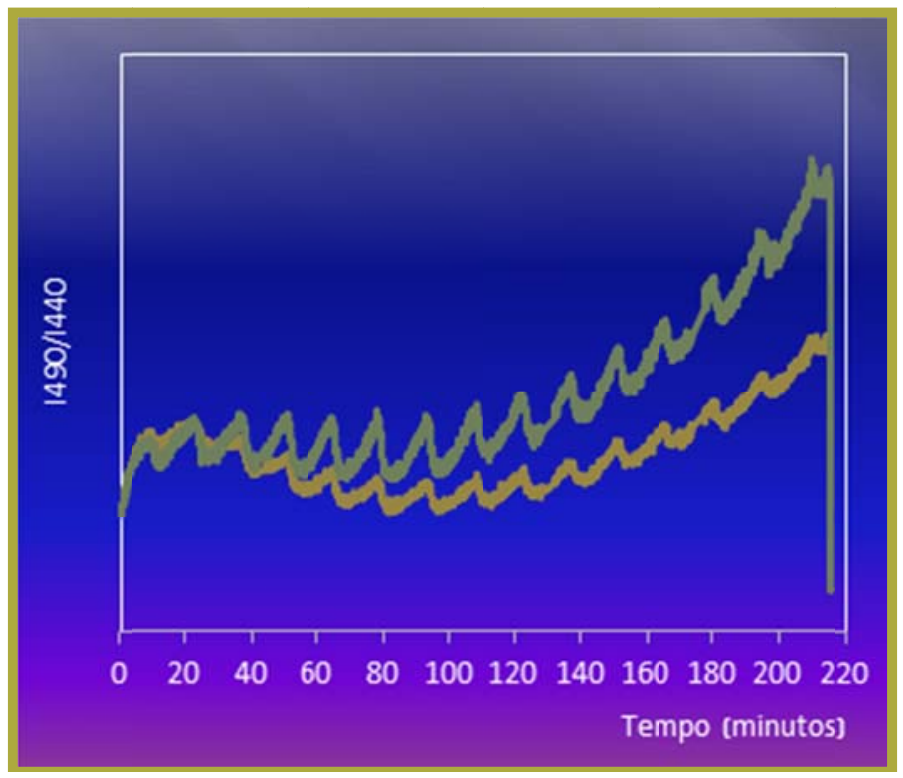


Figura 40 - Registro de $\mathrm{pHi}$ de osteoclastos diferenciados in vivo. As oscilações do pHi não foram abolidas por ausência de $\mathrm{Na}^{+}$extracelular, por ausência de $\mathrm{Cl}^{-}$extracelular, por concanamicina $(100 \mathrm{mM})$ (inibidor da $\mathrm{H}^{+}$ATPase) ou por NPPB $(100 \mu \mathrm{M})$ (inibidor de canais para cloreto). As setas indicam o momento de aplicação dos inibidores ou de substituição das soluções. No eixo x estão indicados os valores absolutos de duração dos experimentos, em minutos. No experimento com concanamicina, a solução contendo nigericina a $\mathrm{pH} 7,0$ foi aplicada aos 230 minutos

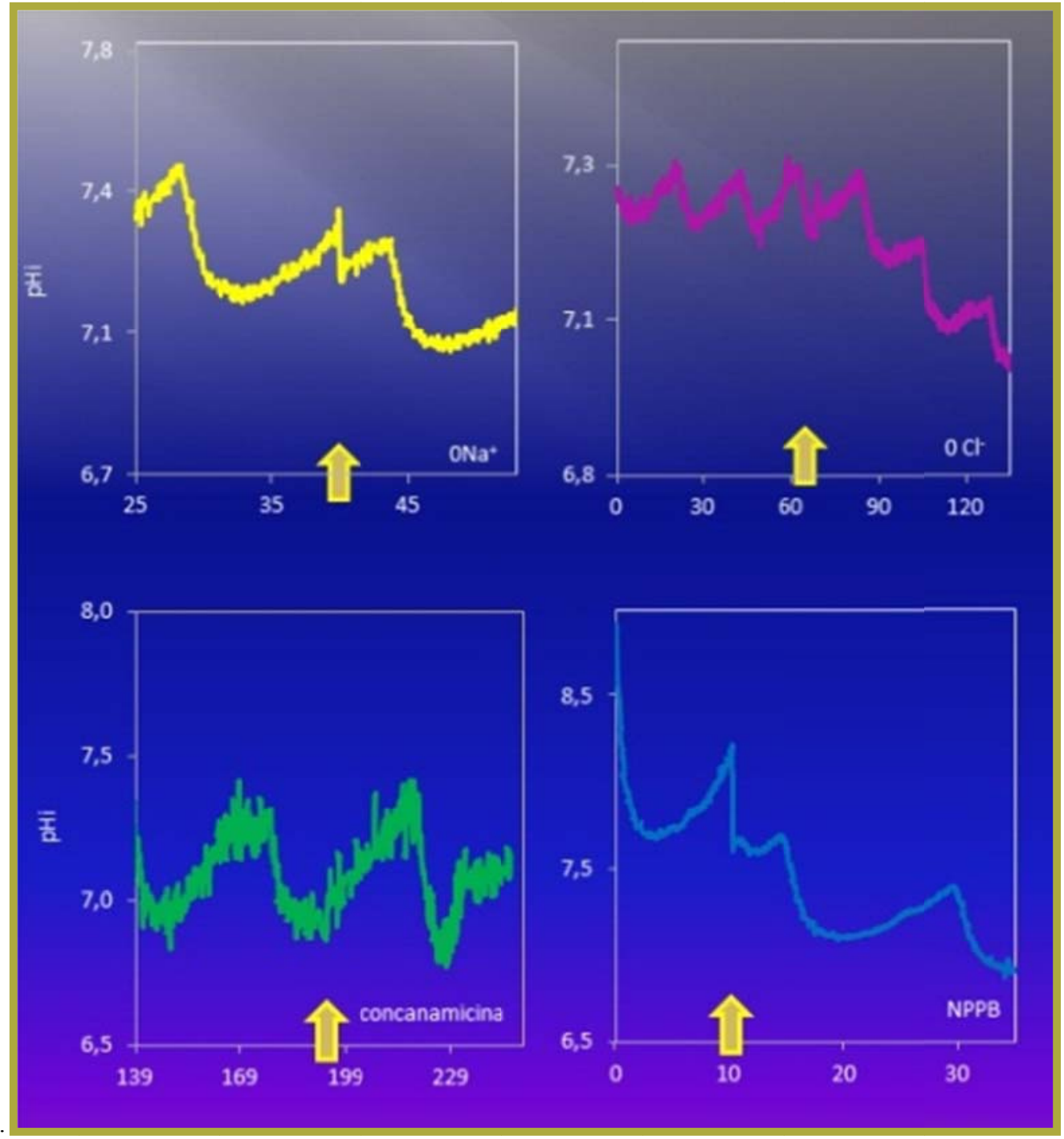


Figura 41 - Registro de pHi de osteoclasto diferenciado in vivo. A ausência de $\mathrm{Cl}^{-}$extracelular modificou o padrão das oscilações do pHi. $\mathrm{O}$ momento de troca da solução controle $\left(\mathrm{Cl}^{-} 135 \mathrm{mM}\right)$ para a $0 \mathrm{Cl}^{-}$ está indicado pela primeira seta da esquerda para a direita; o momento da troca da solução $0 \mathrm{Cl}^{-}$para a solução controle está indicado pela segunda seta. Aos 242 minutos, foi aplicada a solução contendo nigericina a $\mathrm{pH}$ 7,0. Para este osteoclasto, os valores de $\mathrm{pH}$ máximo ( $\mathrm{pH}$ máx) entre os dois primeiros picos consecutivos foram de 7,30 para 7,27 na vigência de solução controle, e de 7,26 para 7,16 na vigência de solução $0 \mathrm{Cl}^{-}$. Os valores de $\mathrm{pH}$ mínimo ( $\mathrm{pH}$ mín) entre os dois primeiros vales consecutivos foram de 7,22 para 7,21 na vigência de solução controle, e de 7,15 para 7,03 na vigência de solução $0 \mathrm{Cl}^{-}$. O tempo de alcalinização intracelular (t1) foi de 15 minutos na vigência de solução controle, e de 12 minutos na vigência de solução $0 \mathrm{Cl}^{-}$. O tempo de acidificação intracelular (t2) foi de 6 minutos na vigência de solução controle e de 9 minutos na vigência de solução $0 \mathrm{Cl}^{-}$. A taxa de secreção de $\mathrm{H}^{+}(\tau 1)$ foi de 0,004 unidade de $\mathrm{pH} / \mathrm{min}$ na vigência de solução controle e de 0,0008 unidade de $\mathrm{pH} / \mathrm{min}$ na vigência de solução $0 \mathrm{Cl}^{-}$. A taxa de acidificação intracelular $(\tau 2)$ foi de 0,015 unidade de $\mathrm{pH} / \mathrm{min}$ na vigência de solução controle e de 0,012 unidade de $\mathrm{pH} / \mathrm{min}$ na vigência de solução $0 \mathrm{Cl}^{-}$.

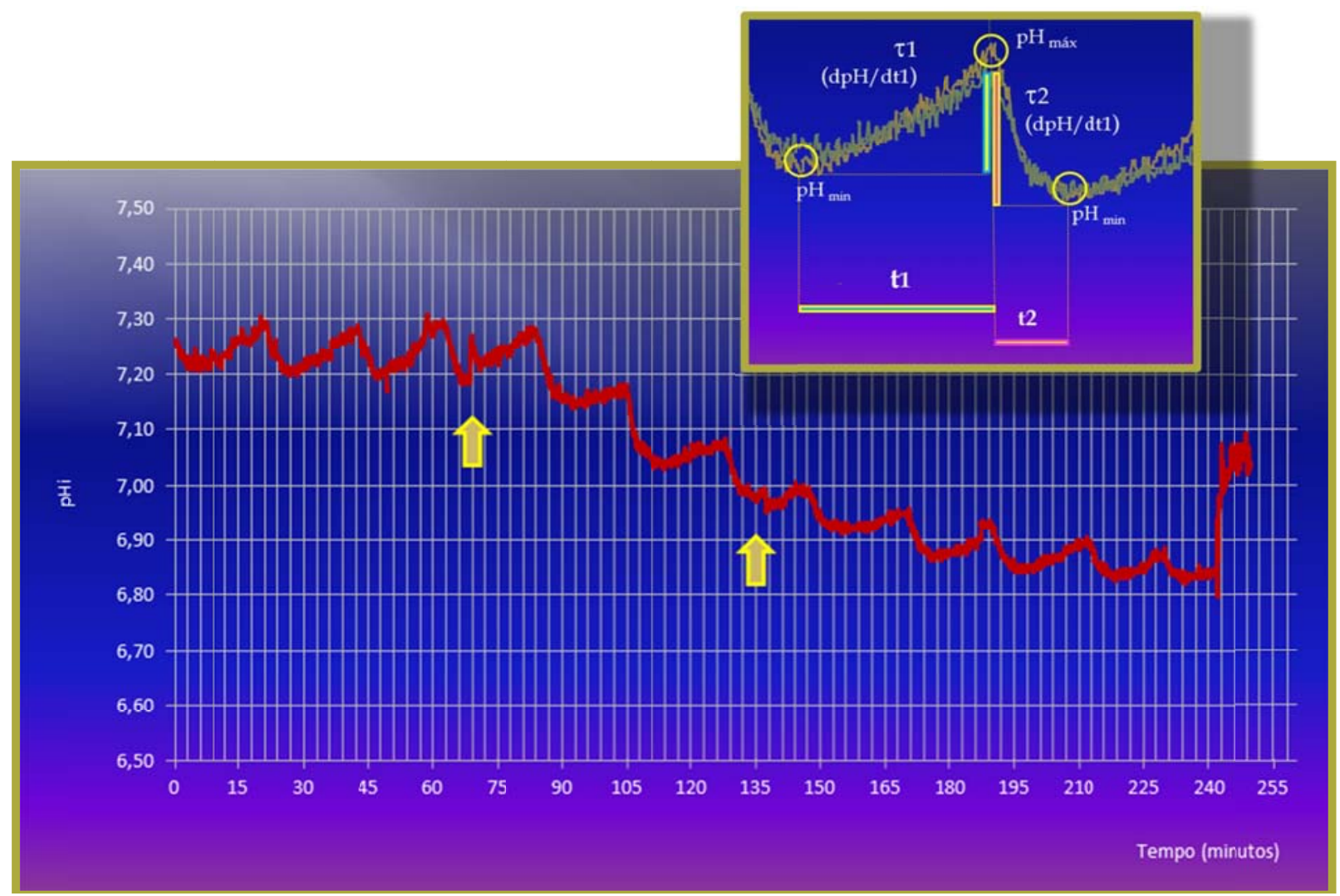

Nos experimentos com acidificação induzida em osteoclastos diferenciados in vitro, na vigência de perfusão a $5 \mathrm{ml} / \mathrm{min}$, o NPPB aboliu $(\mathrm{n}=4)$ e a bafilomicina não aboliu $(\mathrm{n}=3)$ a secreção de $\mathrm{H}^{+}$nos primeiros dois minutos após a máxima acidificação (Figura 42). $\mathrm{O} \mathrm{Zn}^{2+}$ aboliu a secreção de $\mathrm{H}^{+}$nos primeiros dois minutos, na ausência de perfusão (Figura 43). 
Figura 42 - Registro de pHi de osteoclastos diferenciados in vitro e submetidos a acidificação induzida. Em A, dois osteoclastos diferenciados in vitro submetidos a acidificação induzida; a primeira seta da esquerda para a direita indica o início da secreção de $\mathrm{H}^{+}$na vigência de solução controle e a segunda seta indica a abolição da secreção de $\mathrm{H}^{+}$na vigência de NPPB. Em B, três osteoclastos diferenciados in vitro submetidos a acidificação induzida; a seta indica o início da secreção de $\mathrm{H}^{+}$na vigência de bafilomicina. Em A e B, os osteoclastos foram perfundidos $(5 \mathrm{ml} / \mathrm{min})$ durante todo o experimento.

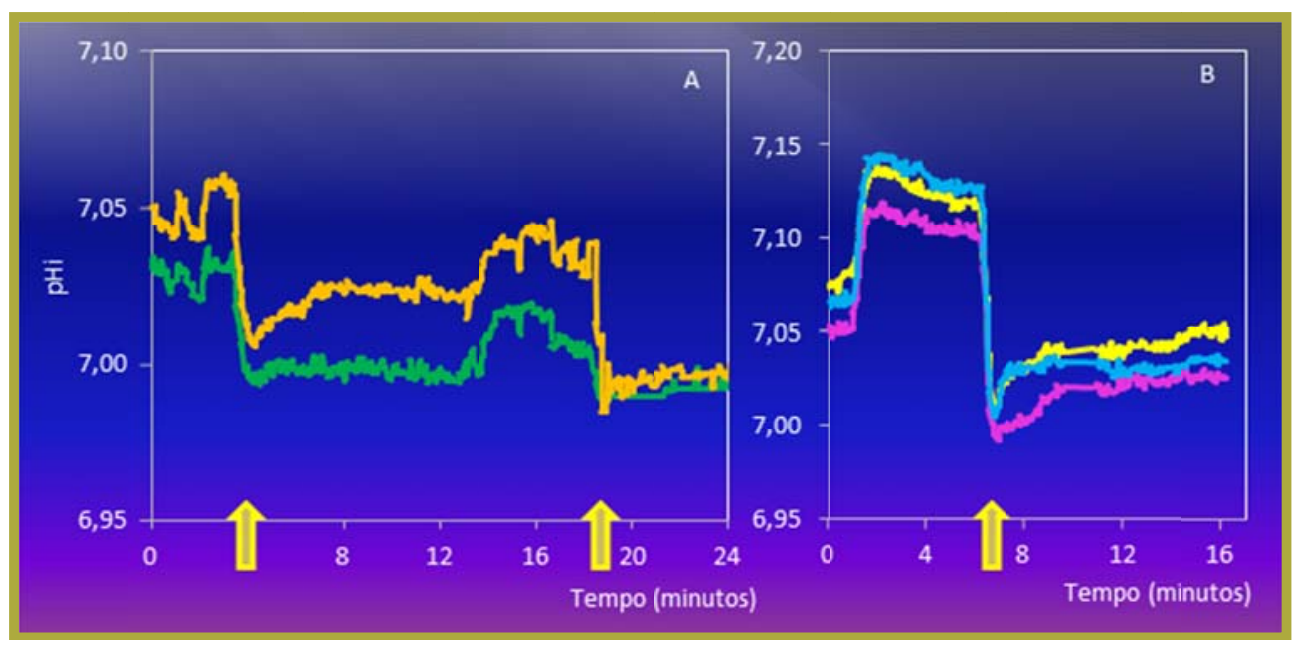

Figura 43 - Registro de pHi de três osteoclastos diferenciados in vitro submetidos a acidificação induzida. Em A, secreção de $\mathrm{H}^{+}$na vigência de solução controle; em $\mathbf{B}$, abolição da secreção de $\mathrm{H}^{+}$na vigência de $\mathrm{Zn}^{2+}$. O experimento (parte A e B) foi realizado sem perfusão.

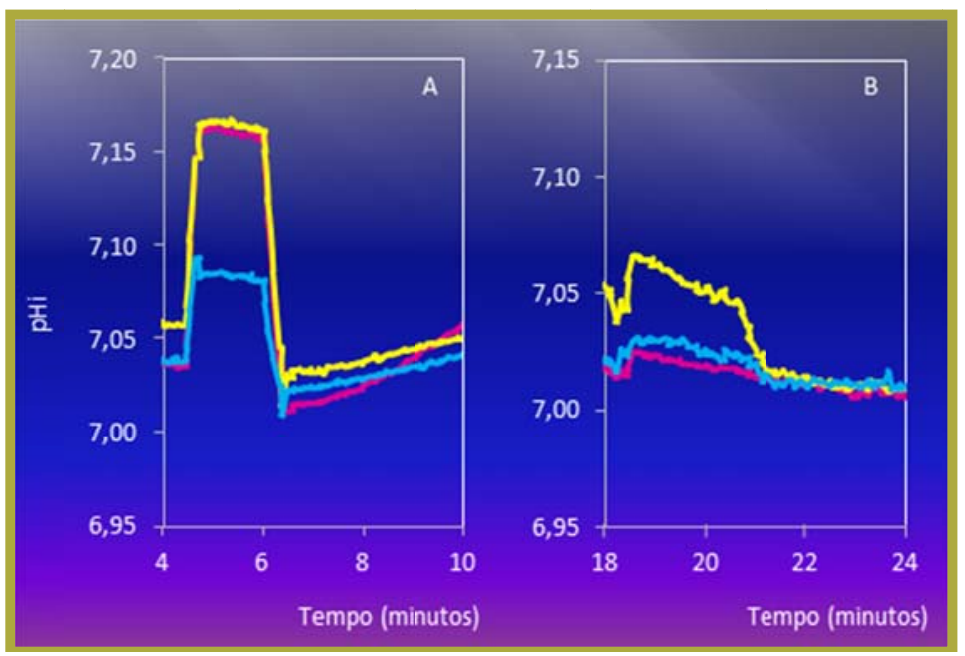

Em osteoclastos diferenciados in vitro, foram observadas oscilações espontâneas do pHi na ausência de perfusão. Na presença de perfusão, a secreção de $\mathrm{H}^{+}$após acidificação induzida foi ausente ou breve e não sustentada, conforme apresentado na Figura 44. Não há correlação entre o tamanho celular e dpHi/dt após carga ácida $(p=0,5060, n=20$; Spearman, "two-tailed"). Em osteoclastos diferenciados in vivo e in vitro, a perfusão contínua causou acidificação celular progressiva. A interrupção da perfusão coincidiu com o início da secreção de $\mathrm{H}^{+}$e da alcalinização celular, conforme apresentado nas Figuras 45 a 47. 
Figura 44 - Registro de pHi de osteoclastos diferenciados in vitro submetidos a acidificação induzida. Na presença de perfusão, foram observadas oscilações espontâneas iniciais do pHi e a secreção de $\mathrm{H}^{+}$ foi ausente (A) ou breve e não-sustentada (B).



Figura 45 - Registro de pHi de osteoclastos diferenciados in vitro, o exerimento foi iniciado com perfusão (5 ml/min). Em A, observam-se oscilações iniciais espontâneas e não-sincrônicas no início do experimento, as quais não se reperiram durante a vigência da perfusão, interrompida aos $\sim 45$ minutos, momento indicado pela primeira seta da esquerda para a direita. Durante a vigência da perfusão, foi aplicada a solução contendo $\mathrm{NH}_{4} \mathrm{Cl}(20 \mathrm{mM})(\mathbf{B})$. Imediatamente após a interrupção da perfusão, iniciou-se a secreção de $\mathrm{H}^{+}$; com o reinício da perfusão, indicado pela segunda seta, houve abrupta acidificação intracelular e cessou a secreção de $\mathrm{H}^{+}(\mathbf{C}) \cdot \mathrm{A}$ solução de $\mathrm{NH}_{4} \mathrm{Cl}$ foi novamente aplicada aos $\sim 63$ minutos (D). Em E, está indicado o momento da aplicação da nigericina a $\mathrm{pH} 7,0$ e a interrupção da perfusão, que coincidiu com o início da secreção de $\mathrm{H}^{+}$. A interrupção da perfusão coincide com a ocorrência de oscilações esponâneas do pHi, como observado em $\mathbf{F}$. As oscilações espontâneas na presença (A) e na ausência de perfusão (F) estão destacadas nos gráficos à direita.
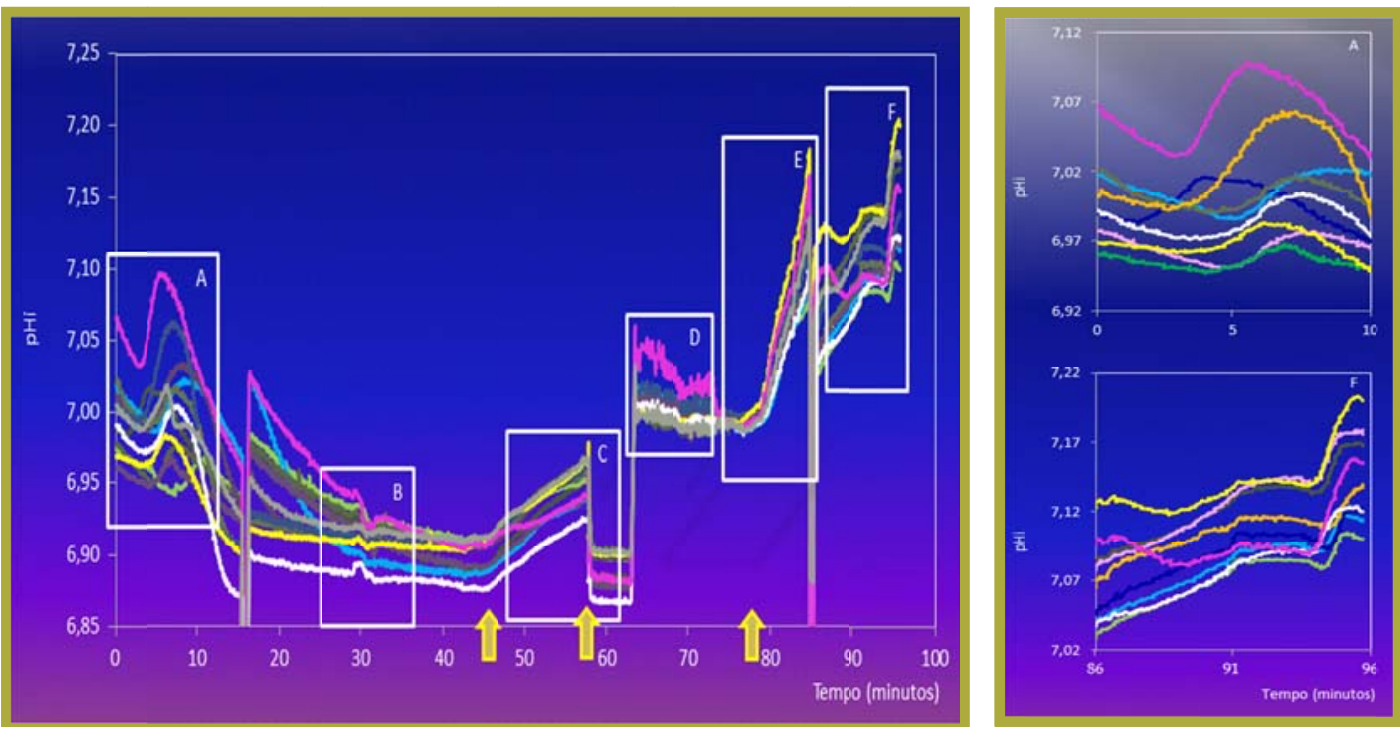
Figura 46 - Registro de pHi de três osteoclastos diferenciados in vitro submetidos a acidificação induzida durante a perfusão contínua, que causou acidificação celular progressiva até sua interrupção. A interrupção da perfusão, indicada pela primeira seta da esquerda para a direita, coincidiu com o início da secreção de $\mathrm{H}^{+}$e da alcalinização celular. Após atingido um valor máximo, houve queda espontânea do pHi. O período de alcalinização espontânea que se seguiu (aos 30 minutos) foi interrompido pelo reinício da perfusão, indicado pela segunda seta, quando se iniciou a acidificação celular progressiva.

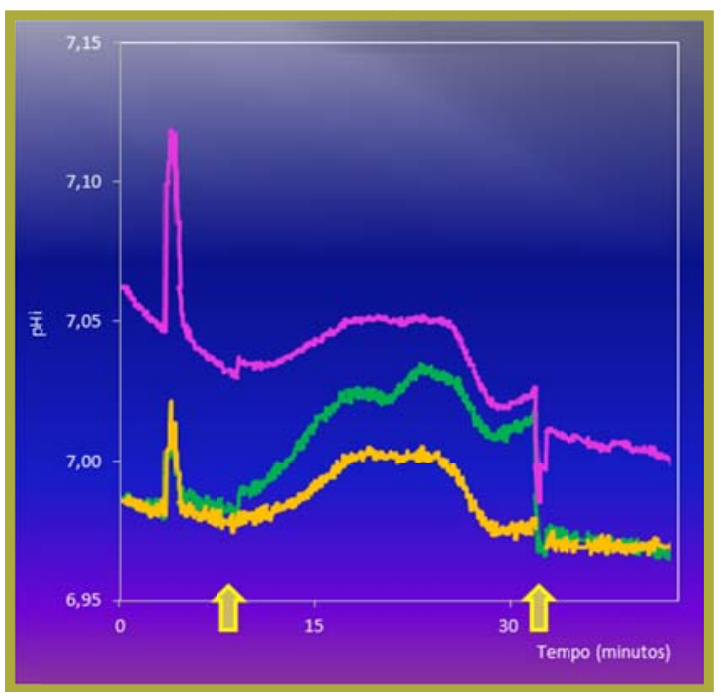

Figura 47 - Registro de pHi de osteoclastos diferenciados in vivo, acima, e in vitro, abaixo. Em A, o traçado em fúcsia corresponde ao registro do pHi registrado na presença de perfusão contínua e o verde, na ausência de perfusão. Ocorrem oscilações espontâneas na ausência de perfusão e acidificação progressiva durante sua vigência. Em B, a seta indicada o momento em que foi interrompida a perfusão, quando foi registrado o início da alcalinização celular. Em $\mathrm{C}$, a seta indica o início da perfusão. Em E, o período compreendido entre as duas setas corresponde à aplicação da nigericina a pH 7,0. A segunda seta da esquerda para a direita indica a substituição da solução contendo nigericina por solução controle e a interrupção da perfusão, que coincidiu com o início da secreção de $\mathrm{H}^{+}$. (Obs.: As letras não estão em ordem sequencial pois os registros $\mathrm{C}$ e E correspondem a trechos do registro de pHi apresentado na Figura 45.)
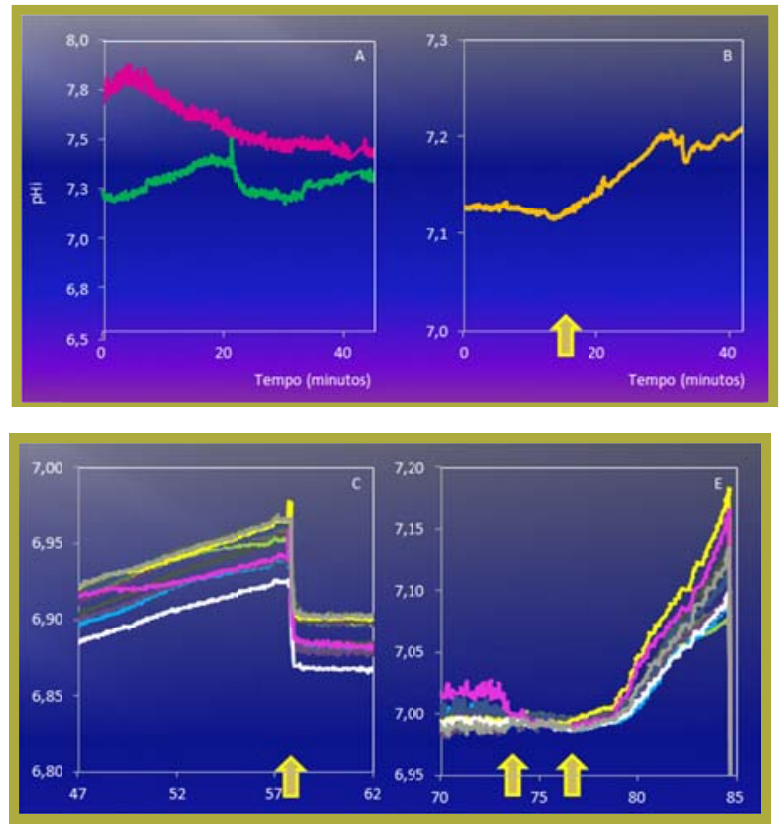


\subsection{DIFERENCIAÇÃO DE PRECURSORES EM OSTEOCLASTOS EM ACIDOSE METABÓLICA}

A diferenciação sobre superfície de fosfato de cálcio (Osteo Assay Surface, Corning $\left.{ }^{\circledR}\right)$ não foi modificada pela acidose. A contagem de núcleos individualizados evidenciados por DAPI mostrou diferenças não significativas no número absoluto de células (Figura 48).

Entretanto, o tratamento com os inibidores dos transportadores de $\mathrm{H}^{+}$afetou significativamente a diferenciação. $\mathrm{O} \mathrm{Zn}^{2+}$ reduziu o numero de núcleos individualizados, indicando a redução do número de células mononucleares e a formação de osteoclastos multinucleados, tanto em $\mathrm{pH} 7,4$ quanto em $\mathrm{pH}$ 6,9, enquanto a bafilomicina e o NPPB provocaram morte celular, como apresentado nas Figuras 48 a 50.

Figura 48 - Número de núcleos individualizados de osteoclastos corados por DAPI (detalhe) diferenciados sobre superfície de fosfato de cálcio (Osteo Assay Surface, Corning) em pH 6,9 e 7,4. Não houve diferença significativa no número de núcleos individualizados entre os dois grupos (controle versus controle, $\mathrm{p}=0,5457$, “two-tailed”, Mann Whitney). $\mathrm{O}$ tratamento com $\mathrm{Zn}^{2+}$ (zinco) causou redução significativa em relação ao controle nos dois pHs estudados $(\mathrm{p}=0,03$; para $\mathrm{pH} 7,4 \mathrm{e} \mathrm{p}=0,021$; para pH 6,9 - Mann Whitney, "one-tailed") (controle, $\mathrm{n}=9 ; \mathrm{Zn}^{2+}, \mathrm{n}=5 ; \mathrm{NPPB}, \mathrm{n}=5$, bafilomicina, $\mathrm{n}=5$ ). A contagem do núcleos após tratamento com NPPB em pH 6,9 não foi diferente de zero.
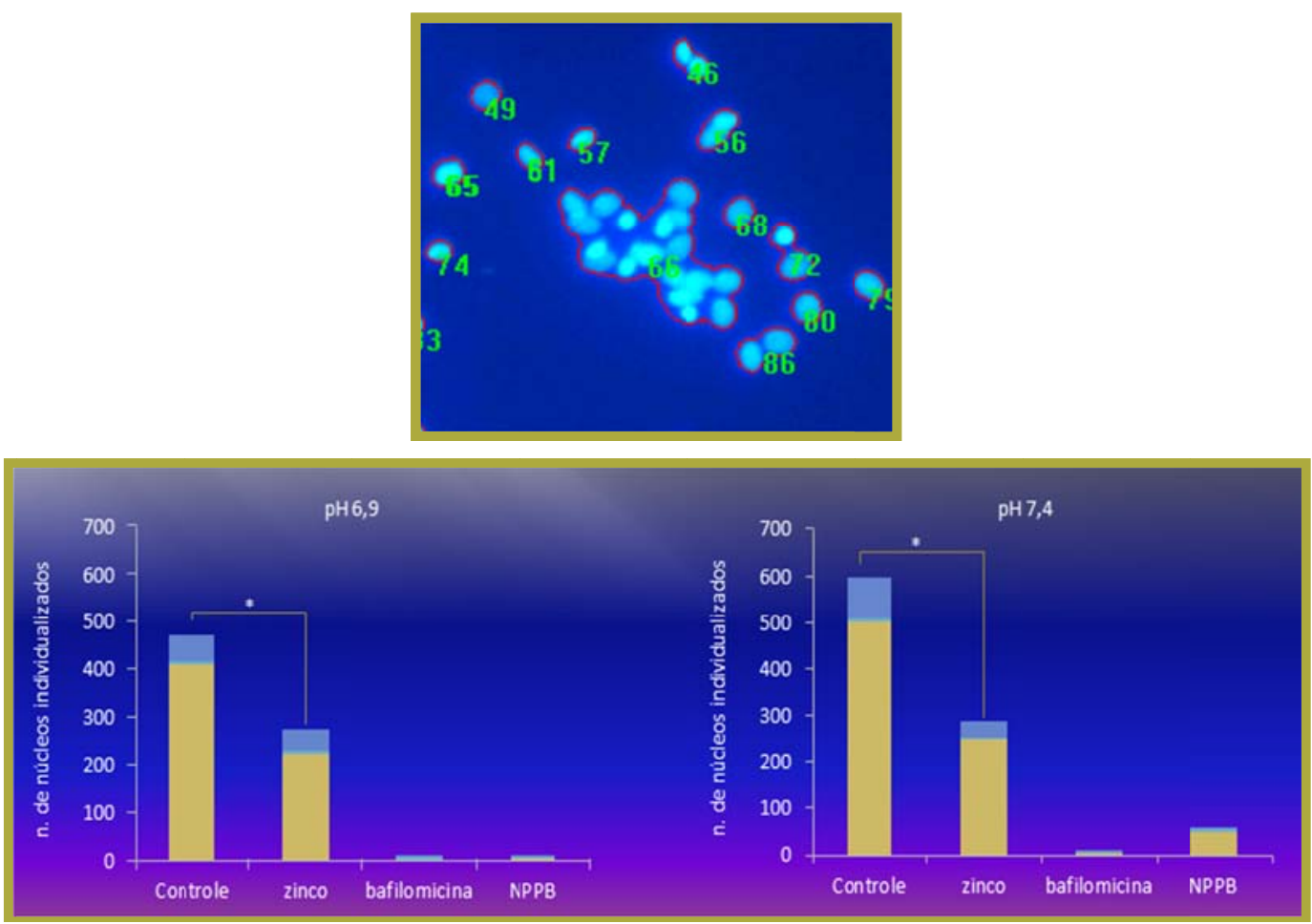
Figura 49 - Imagens dos núcleos de osteoclastos, evidenciados por DAPI, diferenciados in vitro sobre Osteo Assay Surface (Corning). Em A e B, osteoclastos diferenciados em pH 7,4; em C e D, osteoclastos diferenciados em pH 6,9. À esquerda, controle $(\mathbf{A}$ e $\mathbf{C})$ e à direita $(\mathbf{B}$ e $\mathbf{D})$, tratamento com $\mathrm{Zn}^{2+}$. O $\mathrm{Zn}^{2+}$ causou redução do número de núcleos individualizados, indicando a formação de osteoclastos maiores, multinucleados (aumento $20 \mathrm{X}$ ).

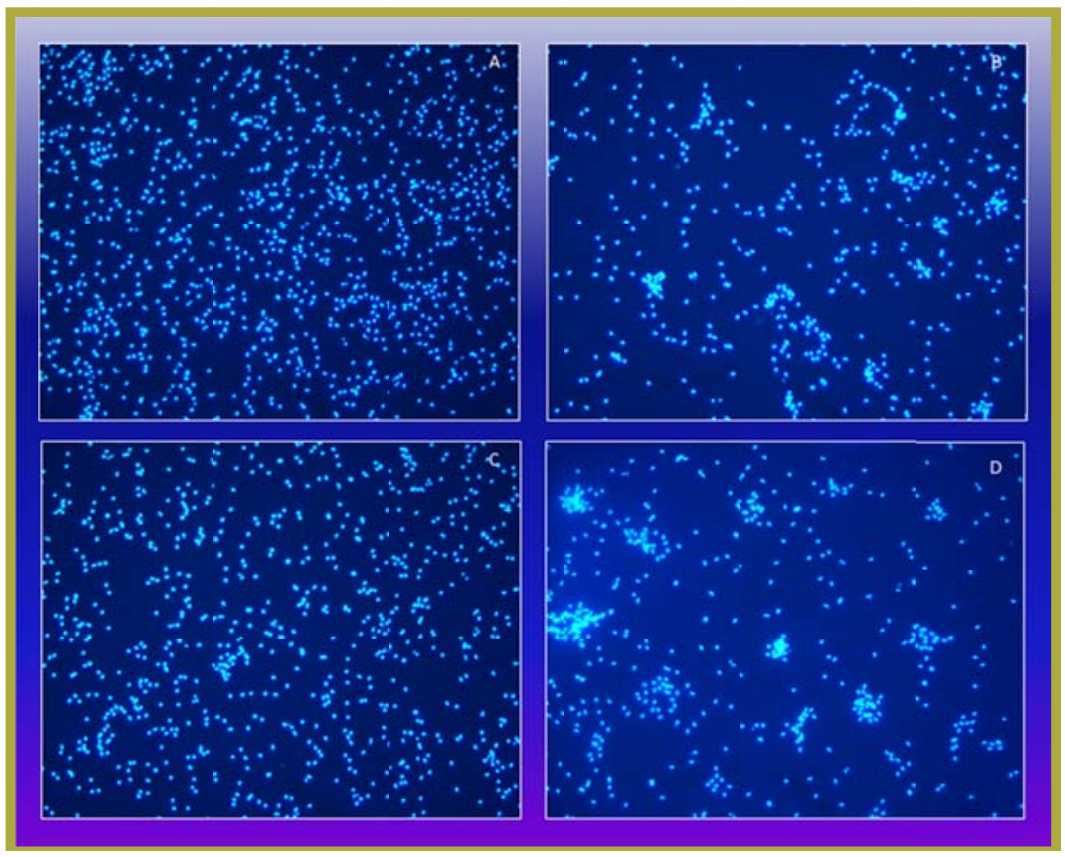

Figura 50 - Osteoclastos diferenciados in vitro sobre Osteo Assay Surface (Corning) em pH 6,9. Em A e B, imunofluorescência para $\mathrm{H}^{+}$-ATPase, em $\mathbf{C}$ e D, núcleos evidenciados por DAPI. À esquerda, controle $\left(\mathbf{A}\right.$ e C) e à direita (B e D), tratamento com $\mathrm{Zn}^{2+}$. O tratamento com $\mathrm{Zn}^{2+}$ ocasionou a formação de osteoclastos maiores, multinucleados (aumento $20 \mathrm{X}$ ).

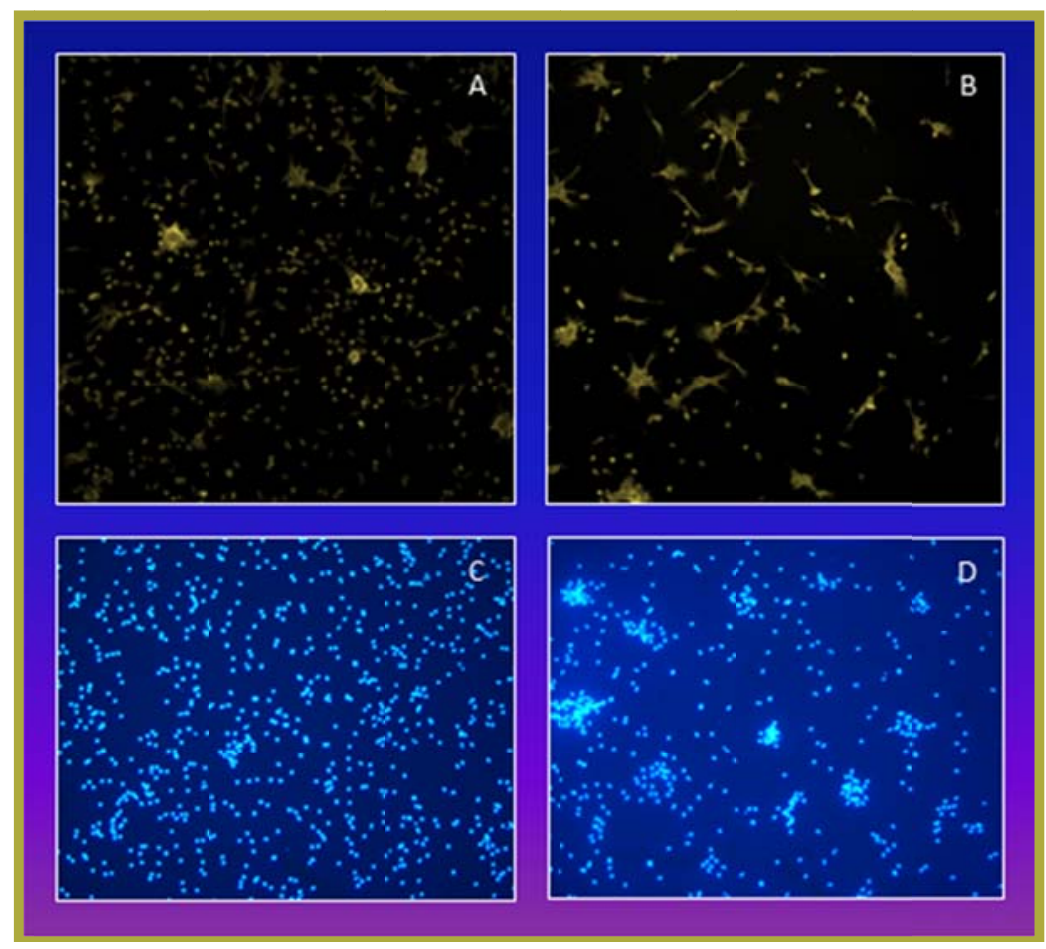


Contrariamente à redução do número de osteoclastos observada na diferenciação in vitro sobre superfície de fosfato de cálcio (Osteo Assay Surface, Corning®), o tratamento com $\mathrm{Zn}^{2+}$ dos osteoclastos diferenciados sobre osso em $\mathrm{pH}$ 6,9 causou aumento significativo do número de células TRAP+, como apresentado na Figura 51.

Figura 51 - Número de osteoclastos evidenciados por TRAP (células TRAP+) diferenciados in vitro sobre osso. $\mathrm{O}$ tratamento com $\mathrm{Zn}^{2+}$ em pH 6,9 causou aumento significativo do número de células TRAP+ em relação ao grupo não-tratado (controle versus $\mathrm{Zn}^{2+}-\mathrm{p}=0,0327$, Mann Whitney, "two-tailed"; $\mathrm{pH} 7,4$, $\left.\mathrm{n}=14 ; \mathrm{pH} 6,9, \mathrm{n}=13 ; \mathrm{pH} 6,9+\mathrm{Zn}^{2+}, \mathrm{n}=8\right)$.

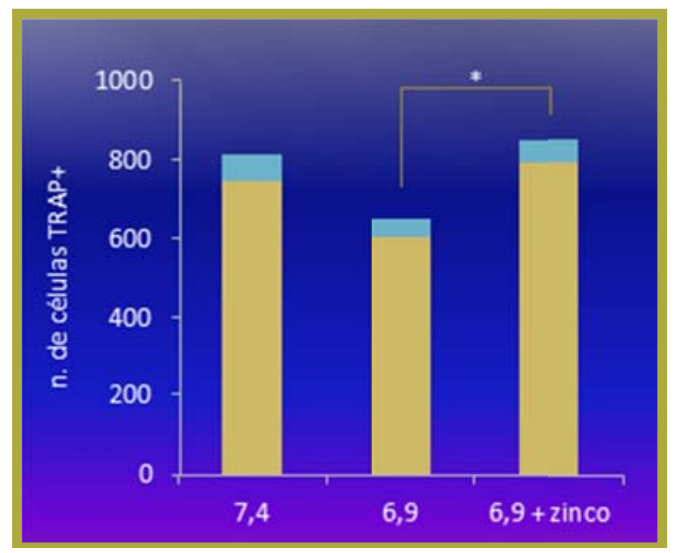

A diferenciação de osteoclastos in vitro sobre plástico revelou diferenças ao longo do tempo na comparação entre pH 6,9 e 7,4. Entre 72 horas $(n=6)$ e 96 horas $(n=3)$ de cultivo na presença de RANKL, houve aumento significativo do número de células diferenciadas em pH 7,4, o que não ocorreu para a diferenciação em pH 6,9 (Figura 52).

Figura 52 - Número de células TRAP+ após 72 horas e 96 horas do início da diferenciação in vitro sobre plástico na presença de RANKL. Entre $72(n=6)$ e 96 horas $(n=3)$, houve aumento significativo do número de células diferenciadas em $\mathrm{pH} 7,4(\mathrm{p}=0,0238$; Mann Whitney, "two-tailed"), o que não ocorreu para a diferenciação em pH 6,9.

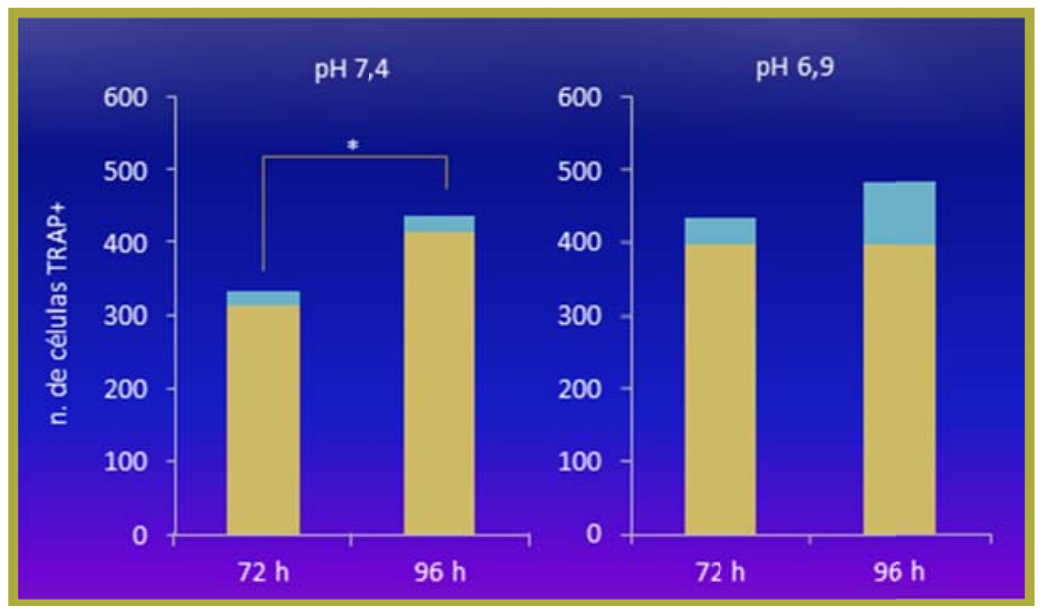




\section{DiscuSSÃo E CONCLUSÕES}

\subsection{SECREÇÃO DE $\mathrm{H}^{+}$}

Uma característica marcante observada nos experimentos de registro de pHi foi a grande variabilidade. Os osteoclastos diferenciados in vivo ou in vitro exibiram taxas de secreção de $\mathrm{H}^{+}$bastante diferentes sob condições experimentais similares. Nas mesmas condições experimentais, em osteoclastos diferenciados in vivo, a secreção de $\mathrm{H}^{+}$nos primeiros minutos após indução da acificação intracelular por exposição a $\mathrm{NH}_{4} \mathrm{Cl}(20 \mathrm{M}$ por 2 minutos) variou de 0,01 a 0,58 unidades de pHi por minuto $(n=27)$.

Em se tratando de osteoclastos, esse fato não representa uma novidade, já que a heterogeneidade é assunto bastante explorado. Diversos autores relataram a heterogeneidade dos osteoclastos com relação à sua capacidade de secreção de $\mathrm{H}^{+}$. Em registros de pHi, Lees e Hersche (2000) registraram valores de pHi bastante variáveis e atribuíram tais diferenças ao tamanho dos osteoclastos. Os autores observaram que o pHi basal foi mais alto em osteoclastos grandes em comparação com o pHi de células menores $(7,7 \pm 0,02$ versus $7,34 \pm 0,02$ ); além disso, foi observado que osteoclastos grandes, contendo dez núcleos ou mais, recuperariam o pHi por meio do trocador $\mathrm{Na}^{+} / \mathrm{H}^{+}$e da $\mathrm{H}^{+}$-ATPase $(60 \%$ das células $)$ ou exclusivamente por meio da $\mathrm{H}^{+}$-ATPase $(40 \%$ das células). Essa interpretação pode ser cômoda do ponto de vista quantitativo, mas é mais provável que, independentemente do tamanho celular, os osteoclastos com diferentes capacidades de secreção de $\mathrm{H}^{+}$estejam em diferentes estágios funcionais em seu curto tempo de vida, que é de sete dias, em média,

Outros dados da literatura apontam o substrato de cultivo e o estágio do ciclo de reabsorção como determinantes da expressão das proteínas transportadores de $\mathrm{H}^{+} \mathrm{em}$ osteoclastos (Zimolo et al., 1995; Shibata et al., 2000; Lees et al., 2001; Lehenkari et al., 1997). Há evidências de que osteoclastos cultivados sobre superfícies reabsorvíveis recuperam o pHi após carga ácida por meio da $\mathrm{H}^{+}$-ATPase e osteoclastos cultivadas sobre vidro o recuperam pelo trocador $\mathrm{Na}^{+} / \mathrm{H}^{+}$(Zimolo et al., 1995; Lehenkari et al., 1997; Shibata et al., 2000). Entretanto, a expressão de $\mathrm{Na}^{+} / \mathrm{H}^{+}$em osteoclastos é assunto cheio de controvérsias. Ravesloot et al. (1995) demonstraram que a maioria dos osteoclastos cultivados sobre vidro secretam $\mathrm{H}^{+}$por meio do trocador $\mathrm{Na}^{+} / \mathrm{H}^{+}$mas que o trocador $\mathrm{Na}^{+} / \mathrm{H}^{+}$e a $\mathrm{H}^{+}$ATPase podem coexistir. Adicionalmente, Hall et al. (1992) investigaram o papel do 
trocador $\mathrm{Na}^{+} / \mathrm{H}^{+}$na reabsorção de osso in vitro, concluindo que essa proteína é essencial para a regulação do pHi na ativação inicial estimulada pela aderência dos osteoclastos ao substrato, evento que leva à ativação do citoesqueleto, "cell spreading" e reabsorção óssea. Já em osteoclastos de aves, Blair et al. (1991) demonstraram não haver participação do trocador $\mathrm{Na}^{+} / \mathrm{H}^{+}$no transporte de prótons $\mathrm{H}^{+}$em estudos de acidificação de vesículas ("inside-out") derivadas de membrana pregueada.

Segundo Bouyer et al. (2007), a recuperação do pHi após acidificação intracelular na ausência de $\mathrm{CO}_{2} / \mathrm{HCO}_{3}{ }^{-}$é mediada quase exclusivamente pelo trocador $\mathrm{Na}^{+} / \mathrm{H}^{+}$, pela $\mathrm{H}^{+}$ATPase e por uma condutância a $\mathrm{H}^{+}$, a qual, segundo Rousselle e Heymann (2002) poderia contribuir para a secreção de $\mathrm{H}^{+}$nos estágios iniciais da acidificação da interface ossoosteoclasto, mas que seria inativada com a acidificação extracelular adicional, desse modo prevenindo a reentrada dos prótons transportados pela V-ATPase. Nordström et al. (1997), entretanto, descreveram que na ausência de $\mathrm{CO}_{2} / \mathrm{HCO}_{3}{ }^{-}$, a regulação do $\mathrm{pH}$ pela $\mathrm{H}^{+}$-ATPase é desprezível em células cultivadas em $\mathrm{pH}$ físiológico, mas torna-se aparente em $40 \%$ das células submetidas a acidose prolongada, condição que estimula a atividade reabsortiva (Arnett, Dempster, 1986; Meghji et al. 2001; Arnett, 2003; Krieger et al. 2004).

É nítido, portanto, que não há um consenso sobre a expressão do trocador $\mathrm{Na}^{+} / \mathrm{H}^{+}$ ou da $\mathrm{H}^{+}$ATPase e sobre a contribuição de cada proteína na secreção de $\mathrm{H}^{+}$pelos osteoclastos. No entanto, nossos resultados apontam que a secreção de $\mathrm{H}^{+}$após carga ácida não depende de $\mathrm{Na}^{+}$extracelular e não foi abolida por bafilomicina $(\mathrm{n}=3)$, o que exclui tanto o trocador $\mathrm{Na}^{+} / \mathrm{H}^{+}$quanto a $\mathrm{H}^{+}$ATPase como mecanismos efetores exclusivos para a secreção de $\mathrm{H}^{+}$após carga ácida intracelular.

Contrariamente, o $\mathrm{Zn}^{2+}(\mathrm{n}=5)$, que causa inibição dos canais para $\mathrm{H}^{+}$dependentes de voltagem, e o NPPB $(n=4)$, inibidor dos canais para $\mathrm{Cl}^{-}$, respectivamente, inibiram a secreção de $\mathrm{H}^{+}$nos dois primeiros minutos após a acidificação intracelular induzida, o que latesta a importância dessas proteínas na regulação do pHi dos osteoclastos (Figuras 42 e 43). Embora o $\mathrm{Zn}^{+}$possa se ligar inespecificamente a diversas proteínas e a canais iônicos, a sensibilidade dos canais para $\mathrm{H}^{+}$dependentes de voltagem ao $\mathrm{Zn}^{2+}$ é maior que a de outros canais iônicos na mesma célula (DeCoursey, 2003).

$\mathrm{O}$ modelo vigente de secreção de $\mathrm{H}^{+}$na interface osso-osteoclasto atribui aos canais $\mathrm{ClC} 7$ a secreção paralela de $\mathrm{Cl}^{-}$para fora da célula, de modo a compensar a hiperpolarização da membrana causada pela saída de $\mathrm{H}^{+}$pela $\mathrm{H}^{+}$ATPase. Entretanto, essa hipótese é oposta àquela que seria prevista para a função do $\mathrm{ClC7}$, que apresenta maior condutância em "single-channel" para a entrada de $\mathrm{Cl}^{-}$na célula. Sobre esse fato, Schlesinger 
et al. (1997) discutem que, devido à característica retificadora da condutância, deve haver pequeno efeito da hiperpolarização da membrana sobre a corrente de $\mathrm{Cl}^{-}$, de modo que o fator determinante e limitante do transporte de $\mathrm{HCl}$ seria o número de canais para $\mathrm{Cl}^{-}$ativados na membrana pregueada.

Nossa interpretação é diferente e está de acordo com a característica retificadora do ClC7. Nossos dados mostram que na ausência de $\mathrm{Cl}^{-}$extracelular, a capacidade de secreção de $\mathrm{H}^{+}$foi significativamente afetada $\left(\mathrm{n}=3\right.$. Em um dos nossos registros, a taxa de secreção de $\mathrm{H}^{+}$ ( $\tau 1)$ foi de 0,004 unidade de $\mathrm{pH} /$ min na vigência de solução controle para 0,0008 unidade de $\mathrm{pH} / \mathrm{min}$ na vigência de solução $0 \mathrm{Cl}^{-}$(Figura 41). Adicionalmente, na inibição do $\mathrm{ClC} 7$ por NPPB, verificamos a abolição da secreção de $\mathrm{H}^{+}$após acidificação induzida $(\mathrm{n}=4)$ (Figura 42). Embora haja possibilidade de que a ausência do $\mathrm{Cl}^{-}$e a substituição desse íon cause modificações das propriedades elétricas da membrana celular afetando os canais para $\mathrm{H}^{+}$ dependentes de voltagem, a característica retificadora do $\mathrm{ClC} 7$ e os nossos resultados indicam que os osteoclastos secretam $\mathrm{H}^{+}$por $\mathrm{ClC} 7$. Outros resultados coerentes com essa proposição, estão documentados no trabalho de Graves et al. (2008), que demonstraram que o "knockdown” da expressão de CLC7 por RNA de interferência abole a atividade do trocador $\mathrm{Cl}^{-} / \mathrm{H}^{+}$lisossomal e diminui a capacidade de acidificação de lisossomos in vivo.

Nos registros de pHi realizados com osteoclastos diferenciados in vivo na ausência de fluxo de fluido extracelular, ocorreram variações cíclicas do pHi caracterizadas por períodos repetidos de acidificação e alcalinização espontâneas. O período das oscilações variou de 12 a 45 minutos $(\mathrm{n}=35)$ e a amplitude das oscilações variou de 0,12 a 1,43 unidades de pHi (Figura 38). A presença de fluxo de fluido extracelular não estabilizou o pHi, mas, em vez disso, provocou acidificação progressiva. Adicionalmente, as oscilações do pHi não foram abolidas por concanamicina $(\mathrm{n}=3)$, por NPPB $(\mathrm{n}=3)$, na ausência de $\mathrm{Na}^{+}$extracelular $(\mathrm{n}=5)$ ou na ausência de $\mathrm{Cl}^{-}$extracelular $(\mathrm{n}=3)$. Entretanto, na ausência de $\mathrm{Cl}^{-}$extracelular houve modificação significativa do padrão das oscilações $(n=3)$ (Figuras 40 e 41), com redução da capacidade de secreção de $\mathrm{H}^{+}$em cada ciclo, o que indica a participação do $\mathrm{ClC7}$ na secreção de $\mathrm{H}^{+}$em troca por $\mathrm{Cl}^{-}$. Adicionalmente, em nossos registros de oscilação do pHi de osteoclastos na ausência de $\mathrm{Cl}^{-}$extracelular, observamos redução de $20 \%$ no tempo de secreção de $\mathrm{H}^{+}$(Figura 41), ou seja, o período de alcalinização intracelular foi encurtado em cada ciclo. Consideramos que a alcalinização celular ocorreu devido à secreção de $\mathrm{H}^{+}$já que os experimentos foram realizados na ausência $\mathrm{CO}_{2} / \mathrm{HCO}_{3}^{-}$, e, portanto não poderia haver entrada de $\mathrm{HCO}_{3}{ }^{-}$para a alcalinização celular. 
O fluxo de fluido prejudicou a secreção de $\mathrm{H}^{+}$após acidificação induzida (Figura 44) e aboliu as oscilações do pHi (Figuras 45 e 46), e a cessação de um período de fluxo contínuo coincidiu com o início da secreção de $\mathrm{H}^{+}$(Figura 47). De acordo com nossa interpretação, a ausência de fluxo poderia contribuir para a inversão da direção do transporte de $\mathrm{H}^{+}$e influxo de $\mathrm{H}^{+}$por meio dos canais para $\mathrm{H}^{+}$dependentes de voltagem. Essa conclusão é fundamentada na lei de ação das massas, que estabelece que a velocidade de uma reação química é proporcional à concentração dos reagentes. Assim, o tamponamento do $\mathrm{H}^{+}$ secretado ocorre mais rapidamente na presença de perfusão, uma vez que durante a perfusão os tampões presentes na solução extracelular são continuamente repostos, de modo que a célula "vê" sempre uma nova molécula aceptora de $\mathrm{H}^{+}$. Inversamente, na ausência de perfusão, é favorecido o aumento da espessura da camada estacionária (volume de fluido paralelo à membrana celular), de modo que $\mathrm{o}^{+}$secretado leva mais tempo para se difundir para o seio da solução, o que favorece o aumento da concentração de $\mathrm{H}^{+}$na camada estacionária e a inversão do gradiente de $\mathrm{H}^{+}$nas imediações do canal. Qualquer medida de transporte iônico através da membrana celular é afetada pela presença da camada estacionária, sendo que na presença de fluxo, essa é reduzida. A difusão do $\mathrm{H}^{+}$na camada estacionária na presença ou ausência de fluxo, assim como a concentração do tampão, no nosso caso o HEPES, determinam a velocidade de transporte do $\mathrm{H}^{+}$por meio dos canais para $\mathrm{H}^{+}$ dependentes de voltagem. De acordo com Gutknecht e Tosteson (1973), quando há baixa capacidade tamponante no meio extracelular, estabelece-se um alto gradiente de concentração de $\mathrm{H}^{+}$na camada estacionária e, ao contrário, quando a concentração de $\mathrm{H}^{+}$na camada estacionária é baixa, o tampão provê $\mathrm{H}^{+}$, de modo que a taxa de difusão do $\mathrm{H}^{+}$através da camada estacionária é fator determinante da taxa de transporte de $\mathrm{H}^{+}$através da membrana celular.

Nossos resultados atestam a importância do gradiente de $\mathrm{pH}$ na determinação da magnitude da secreção de $\mathrm{H}^{+}$. Verificamos que a secreção de $\mathrm{H}^{+}$após acidificação induzida em osteoclastos diferenciados em in vivo está correlacionada ao gradiente de $\mathrm{pH}(\mathrm{p}=0,0036$, $\mathrm{n}=27$ ) (Figura 35), o que é coerente com transporte passivo. $\mathrm{A}^{+}$ATPase vacuolar é um transportador ativo, que pode transportar $\mathrm{H}^{+}$contra um amplo gradiente de $\mathrm{pH}$. Assim, a observação de Sakai et al. (2006) de que a secreção ácida pela V-ATPase do osteoclasto é modulada pelo gradiente de $\mathrm{pH}$ (pHe- $\mathrm{pHi}$ ) está desconsiderando a existência dos canais para $\mathrm{H}^{+}$na membrana dos osteoclastos.

As correntes de $\mathrm{H}^{+}$podem ter duração de minutos com aumento crescente de sua magnitude até atingirem um pico de corrente máxima, a partir do qual decaem abruptamente. 
$\mathrm{O}$ decaimento das correntes não é resultado da inativação, uma vez que os canais para $\mathrm{H}^{+}$ dependentes de voltagem não se inativam, mas deve-se ao aumento do pHi devido à saída de $\mathrm{H}^{+}$(DeCoursey, 2003). Nos experimentos em que registramos oscilação do pHi, o período de secreção de $\mathrm{H}^{+}$foi sempre maior que o tempo de acidificação celular (Figuras 38 a 41, 46 e 47) indicando diferentes cinéticas de transporte de $\mathrm{H}^{+}$dependendo da sua direção. Esse dado corrobora para a conclusão de que as oscilações de pHi são determinadas pelo transporte de $\mathrm{H}^{+}$pelos canais para $\mathrm{H}^{+}$dependentes de voltagem, já que o padrão oscilatório registrado é coerente com as características biofísicas do canal, que possuem cinética de ativação lenta e de desativação rápida.

A propriedade dos canais para prótons dependentes de voltagem de serem modulados por $\mathrm{pH}$ resulta na ativação da condutância para saída de prótons da célula, o que levou ao consenso de que a função primária dos canais é a secreção de $\mathrm{H}^{+}$. Entretanto, correntes de entrada de $\mathrm{H}^{+}$também foram registradas com a inversão do gradiente de $\mathrm{pH}$ em $-80 \mathrm{mV}$ (DeCoursey, 2003). Influxo de $\mathrm{H}^{+}$sensível a $\mathrm{Zn}^{2+}$ foi também descrito em neurônios durante recuperação de carga intracelular alcalina (Frey, Schlue, 1993). A H ${ }^{+}$ATPase, por sua vez, funciona exclusivamente como bomba de $\mathrm{H}^{+}$, não sendo reversível.

A interpretação de nossos resultados sustenta a conclusão de que as oscilações de pHi ocorrem por atividade conjunta dos canais para $\mathrm{H}^{+}$dependentes de voltagem e das proteínas ClC7. Isso porque, no período de secreção de $\mathrm{H}^{+}$na ausência de $\mathrm{Cl}^{-}$extracelular, observamos que a saída de $\mathrm{H}^{+}$por meio dos canais para $\mathrm{H}^{+}$está comprometida, ou seja, menos $\mathrm{H}^{+}$é secretado por unidade de tempo e a secreção ocorre por período mais curto. $\mathrm{O}$ trocador $\mathrm{ClC} 7$ transporta $\mathrm{Cl}^{-}$em troca por $\mathrm{H}^{+}$com maior capacidade de transporte de $\mathrm{Cl}^{-}$para dentro da célula do que para fora, como já mencionado. Assim, na ausência de $\mathrm{Cl}^{-}$extracelular, condição em que não há entrada de $\mathrm{Cl}^{-}$, a saída de $\mathrm{H}^{+}$por $\mathrm{ClC} 7$ estaria prejudicada, causando a concentração de $\mathrm{H}^{+}$dentro da célula nas imediações do canal para $\mathrm{H}^{+}$dependente de voltagem, mantendo a secreção de $\mathrm{H}^{+}$por meio desses canais. Essa interpretação está de acordo com Graves et al. (2008), que observaram que o CLC7 é a via predominante para o $\mathrm{Cl}^{-}$através da membrana lisossomal e que o colapso do gradiente de $\mathrm{pH}$ abole a captação do $\mathrm{Cl}^{-}$nessas organelas. 


\subsection{DIFERENCIAÇÃO CELULAR}

A literatura sugere que a reabsorção óssea induzida por acidose metabólica ocorra devido ao aumento do número de osteoclastos; entretanto, contrariamente ao esperado, a diferenciação celular em acidose metabólica $(\mathrm{pH}$ 6,9) não foi favorecida em relação ao $\mathrm{pH} 7,4$ (Figuras 48, 49, 51 e 52) em nenhum dos substratos de cultivo utilizados. Por outro lado, o tratamento das culturas com $\mathrm{Zn}^{2+}$ causou redução significativa do número de osteoclastos mononucleares (controle versus $\mathrm{Zn}^{2+}-\mathrm{p}=0,03 \mathrm{em} \mathrm{pH} \mathrm{7,4} \mathrm{e} \mathrm{p}=0,021 \mathrm{em} \mathrm{pH} \mathrm{6,9),} \mathrm{gerando}$ mais células multinucleadas sobre plástico e sobre "Osteo Assay Surface" em relação ao controle não tratado (Figuras 48 a 50). Adicionalmente, o tratamento das células cultivadas sobre osso com $\mathrm{Zn}^{2+}$ causou aumento significativo do número de células TRAP-positivas (controle versus tratado $-\mathrm{p}=0,0327, \mathrm{pH}$ 6,9) (Figura 51). Juntos, esses dados indicam que o $\mathrm{Zn}^{2+}$ é um modulador da diferenciação dos osteoclastos. 


\section{CONSIDERAÇÕES FINAIS}

A secreção de $\mathrm{H}^{+}$nos osteoclastos ocorre por meio dos canais para $\mathrm{H}^{+}$dependentes de voltagem, com participação fundamental das proteínas $\mathrm{ClC} 7$. Considerando que a região a ser reabsorvida é isolada do ambiente geral por um selo de actina, e que as concentrações iônicas na lacuna de reabsorção são unicamente determinadas pela composição da hidroxiapatita e pelo transporte iônico pelo osteoclasto, as oscilações de pHi poderiam ocorrer na lacuna, um ambiente isolado, em que há ausência de fluxo de fluido. Adicionalmente, no tecido ósseo, os tampões liberados com a dissolução da hidroxiapatita poderiam elevar o $\mathrm{pH}$ na lacuna, contribuindo para o estabelecimento e/ou restabelecimento de gradiente de $\mathrm{H}^{+}$favorável à ativação do canais para $\mathrm{H}^{+}$. Desse modo, as modificações de $\mathrm{pH}$ na lacuna poderiam modificar o pHi, e vice-versa, durante o processo de dissolução da hidroxiapatita.

Nosso modelo representa um funcionamento celular com menor dependência de ATP, em que a participação da ATPase poderia estar restrita aos estágios iniciais de secreção de prótons, de modo a promover a dissolução óssea inicial e o estabelecimento do gradiente para a ativação dos canais para $\mathrm{H}^{+}$dependentes de voltagem.

Considerando sua relevância, nossos resultados e conclusões podem indicar novas possibilidades terapêuticas para as doenças osteolíticas no futuro. 


\section{REFERÊNCIAS}

Aguirre JI, Plotkin LI, Stewart SA, Weinstein RS, Parfitt AM, Manolagas SC, Bellido T. Osteocyte apoptosis is induced by weightlessness in mice and precedes osteoclast recruitment and bone loss. J Bone Miner Res 2006 Apr;21(4):605-15.

Alsina M, Guise TA, Roodman GD. Cytokine regulation of bone cell differentiation.Vitam Horm 1996;52:63-98 apud Zaidi M, Blair HC, Moonga BS, Abe E, Huang CL. Osteoclastogenesis, bone resorption, and osteoclastbased therapeutics. J Bone Miner Res 2003;18(4):599-609.

Amgem (C 2007. Material eletrônico distribuído no Congresso da American Society for Bone and Mineral Research. 2009. Toronto, Canadá.

Arnett T. Regulation of bone cell function by acid-base balance. Proc Nutr Soc 2003;62(2):511-20. Review.

Arnett TR, Dempster DW. Effect of $\mathrm{pH}$ on bone resorption by rat osteoclasts in vitro. Endocrinology 1986;119(1):119-24.

Arnett TR, Gibbons DC, Utting JC, Orriss IR, Hoebertz A, Rosendaal M, Meghji A. Hypoxia is a major stimulator of osteoclast formation and bone resorption. J Cell Physiol 2003;196(1):2-8.

Arnett T, Henderson B, editores. Methods in Bone Biology. Londres; Nova Iorque: Chapman \& Hall, 1998.

Baron R, Neff L, Louvard D, Courtoy PJ. Cell-mediated extracellular acidification and bone resorption: evidence for a low $\mathrm{pH}$ in resorbing lacunae and localization of a $100-\mathrm{kD}$ lysosomal membrane protein at the osteoclast ruffled border. J Cell Biol 1985;101(6):2210-22.

Baron R. Molecular mechanisms of bone resorption by the osteoclast. Anat Rec 1989;224(2):317-24.

Beaulieu V, Da Silva N, Pastor-Soler N, Brown CR, Smith PJ, Brown D, Breton S. Modulation of the actin cytoskeleton via gelsolin regulates vacuolar $\mathrm{H}^{+}$-ATPase recycling J Biol Chem 2005;280(9):8452-63.

Bevensee MO, Alper SL, Aronson PS, Boron WF. Control of Intracelular pH. In: Seldin D W, Giebisch G. (Eds.). The Kidney, Physiology and Pathophysiology. 3. Ed. Philadelphia: Lippincott Williams \& Wilkins, 2000. p. 391-442.

Biskobing DM, Fan D. Acid pH increases carbonic anhydrase II and calcitonin receptor mRNA expression in mature osteoclasts. Calcif Tissue Int. 2000 Aug;67(2):178-83.

Biswas RS, Baker D, Hruska KA, Chellaiah MA. Polyphosphoinositides-dependent regulation of the osteoclast actin cytoskeleton and bone resorption. BMC Cell Biol 2004;5:19.

Blair HC. Passive chloride permeability charge coupled to $\mathrm{H}\left({ }^{+}\right)$-ATPase of avian osteoclast ruffled membrane. Am J Physiol 1991;260(6):C1315-C1324.

Boens N, Qin W, Basarić N, Orte A, Talavera EM, Alvarez-Pez JM. Photophysics of the fluorescent $\mathrm{pH}$ indicator BCECF. J Phys Chem A. 2006 Aug 3;110(30):9334-43.

Bonewald LF. Osteocytes. Primer on the Metabolic Bone Diseases and Disorders of Mineral Metabolism. 7th Edition. Washington: Wiley Interscience; 2008. p. 22-27.

Boron WF, De Weer P. Intracellular pH transients in squid giant axons caused by $\mathrm{CO} 2$, NH3 and metabolic inhibitors. J Gen Physiol 1976;67:91-112.

Boyle WJ, Simonet WS, Lacey DL. Osteoclast differentiation and activation. Nature 2003:423:337-342.

Bouyer P, Sakai H, Itokawa T, Kawano T, Fulton CM, Boron WF, Insogna KL. Colony-stimulating factor-1 increases osteoclast intracellular $\mathrm{pH}$ and promotes survival via the electroneutral $\mathrm{Na}^{+} / \mathrm{HCO}_{3}^{-}$cotransporter NBCn1. Endocrinology 2007;148(2):831-40. 
Breton S, Brown D. New insights into the regulation of V-ATPase-dependent proton secretion. Am J Physiol Renal Physiol 2007;292(1):F1-10. Review.

Bushinsky DA: Net calcium effiux from live bone during chronic metaboic but not respiratory acidosis. Am J Physiol 1989 ;256:F836-F842.

Caetano-Lopes J, Canhão H, Fonseca JE. Osteoblasts and bone formation. Acta Reumathologica Portuguesa 2007;32:103-110.

Carraro-Lacroix LR, Lessa LM, Fernandez R, Malnic G. Physiological implications of the regulation of vacuolar H+-ATPase by chloride ions. Braz J Med Biol Res. 2009 Feb;42(2):155-63.

Chatterjee D et al. Sensitivity to vanadate and isoforms of subunits A and B distinguish the osteoclast proton pump from other vacuolar $\mathrm{H}^{+}$ATPases. Proc Natl Acad Sci 1992;89(14):6257-61

Chen SH, Bubb MR, Yarmola EG, Zuo J, Jiang J, Lee BS, Lu M, Gluck SL, Hurst IR, Holliday LS. Vacuolar $\mathrm{H}^{+}$-ATPase binding to microfilaments: regulation in response to phosphatidylinositol 3-kinase activity and detailed characterization of the actin-binding site in subunit B. J Biol Chem 2004;279(9):7988-98.

Cowin SC. The significance of bone microstructure in mechanotransduction. Journal of Biomechanics 2007; 40:S105-S109.

Cowin SC, Moss-Salentijn L, Moss ML. Candidates for the mechanosensory system in bone. J Biomech Eng 1991 May;113(2):191-7.

Coxon F. Material de aula do PhD Trainning Course da European Calcified Tissue Society, 2009. University of Oxford. Oxford, Reino Unido.

DeCoursey TE. Voltage-gated proton channels. Cell Mol Life Sci 2003;65:2554-2573.

Edwards JC, Cohen C, Xu W, Schlesinger PH. C-Src control of chloride channel support for osteoclast HCL transport and bone resorption. J Biol chem. 2006, 201:28011-28022.

Favus MJ, Goltzman D. Regulation of Calcium and Magnesium. In: Primer on the Metabolic Bone Diseases and Disorders of Mineral Metabolism. Am Soc for Bone and Mineral Res 2008;103-108.

Fleet M E , Liu X , King P L , American Mineralogist , 89 (2004) p.1422-1432, Accommodation of the carbonate ion in apatite: An FTIR and X-ray structure study, of crystals synthesized at 2-4 GPa, Sample: xt371.

Francis MJO, Lees RL, Trujillo E, Martin-Vasallo P, Heersche JNM, Mobasheri A. ATPase pumps in osteoclasts and osteoblasts. Int J Biochem \& Cell Biol 2002;34:459-76.

Frey G, Schlue WR. pH recovery from intracellular alkalinization in Retzius neurones of the leech central nervous system. J Physiol 1993;462: 627-643.

Garnero P, Borel O, Byrjalsen I et al. The collagenolytic activity of cathepsin $\mathrm{K}$ is unique among mammalian proteinases. J Biol Chem 1998; 273:32347-52.

Green, Kleeman. Role of bone in regulation of systemic acid-base balance. Editorial Review. Kidney International, Vol. 39 (1991), p. 13.]

Grano M, Faccio R, Colucci S, Paniccia R, Baldini N, Zallone AZ, Teti A. Extracellular $\mathrm{Ca}^{2+}$ sensing is modulated by $\mathrm{pH}$ in human osteoclast-like cells in vitro. Am J Physiol 1994;267(4 Pt 1):C961-8.

Graves AR, Curran PK, Smith CL, Mindell JA. The Cl-/H+ antiporter ClC-7 is the primary chloride permeation pathway in lysosomes. Nature. 2008 Jun 5;453(7196):788-92. 
Grigoriadis AE, Wang ZQ, Cecchini MG, Hofstetter W, Felix R, Fleisch HA, Wagner EF. c-Fos: a key regulator of osteoclast-macrophage lineage determination and bone remodeling. Science 1994;266(5184):443-8.

Gutknecht J, Tosteson DC. Diffusion of weak acids across lipid bilayer membranes: effects of chemical reactions in the unstirred layers. Science 1973;182:1258-1261.

Hall TJ, Schaeublin M, Chambers TJ. $\mathrm{Na}^{+} / \mathrm{H}^{+}$antiporter activity is essential for the induction, but not the maintenance of osteoclastic bone resorption and cytoplasmic spreading. Biochem Biophys Res Commun 1992;188(3):1097-103.

Hilden SA, Johns CA, Madias NE. Cl(-)-dependent ATPdriven H+ transport in rabbit renal cortical endosomes. Am J Physiol 1988; 255: F885-F897.

Hoebertz A, Arnett TR. Isolated osteoclast cultures. In: Ralston SH, Helfrich MH, editors. Bone research protocols. Totoma, New Jersey: Humana Press; 2003. P. 53-64.

Jones SJ, Boyde A. Some morphological observations on osteoclasts. Cell Tissue Res 1977(185):387-97.

Kajiya H, Okamoto F, Fukushima H, Okabe K. Calcitonin inhibits proton extrusion in resorbing rat osteoclasts via protein kinase A. Pflugers Arch. 2003 Mar;445(6):651-8.

Kelly ME, Dixon SJ, Sims SM. Outwardly rectifying chloride current in rabbit osteoclasts is actived by hyposmotic stimulation. J Physiol 1994;475:377-89.

Khadeer MA, Tang Z, Tenenhouse HS, Eiden MV, Murer H, Hernando N, Weinman EJ, Chellaiah MA, Gupta A. $\mathrm{Na}^{+}$-dependent phosphate transporters in the murine osteoclast: cellular distribution and protein interactions . Am J Physiol Cell Physiol 2003;284(6):C1633-44.

Kornak U, Kasper D, Bosl MR, Kaiser E, Schweizer M, Schulz A, Friedrich W, Delling G, Jentsch TJ. Loss of ClC-7 chloride channel leads to osteopetrosis in mice and man. Cell 2001;104:205-15.

Krieger NS, Bushinsky DA. Pharmacological inhibition of intracellular calcium release blocks acid-induced bone resorption. Am J Physiol Renal Physiol. 2011 Jan;300(1):F91-7. Epub 2010 Nov 3.

Krieger NS, Frick KK, Bushinsky DA. Mechanism of acid-induced bone resorption. Curr Opin Nephrol Hypertens 2004;13(4):423-36. Review.

Kwon K, Eddie Wang, Alice Chung, Neil Chang, and Seung-Wuk Lee. Effect of salinity on hidroxyapatite dissolution studied by atomic force microscopy. J. Phys. Chem. C, 2009, 113 (9), 3369-3372.

Lee BS, Gluck SL, Holliday LS. Interaction between vacuolar $\mathrm{H}^{+}$-ATPase and microfilaments during osteoclast activation. J Biol Chem. 1999 Oct 8;274(41):29164-71.

Lees RL, Heersche JN. Differences in regulation of $\mathrm{pH}(\mathrm{i})$ in large ( $\geq 10$ nuclei) and small $(\leq 5$ nuclei) osteoclasts. Am J Physiol Cell Physiol 2000;279(3):C751-61.

Lees RL, Sabharwal VK, Heersche JN. Resorptive state and cell size influence intracellular $\mathrm{pH}$ regulation in rabbit osteoclasts cultured on collagen-hydroxyapatite films. Bone 2001;28(2):187-94.

Lehenkari P, Hentunen TA, Laitala-Leinonen T, Tukkanen J, Vaananen HK. Carbonic anydrase II plays a major role in osteoclastic differentiation and bone resorption by effecting the steady state intracellular $\mathrm{pH}$ and $\mathrm{Ca}^{2+}$. Exp Cell Res 1998;242(1):128-37.

Lehenkari PP, Laitala-Leinonen T, Linna TJ, Vaananen HK. The regulation of pHi in osteoclasts is dependent on the culture substrate and on the stage of the resorption cycle. Biochem Biophys Res Commum 1997;235(3):83844.

Li YP, Chen W, Liang Y, Li E, Stashenko P. Atp6i-deficient mice exhibit severe osteopetrosis due to loss of osteoclast-mediated extracellular acidification. Nat Genet 1999;23(4):447-51.

Manolagas SC, Parfitt AM. What old means to bone. Trends in Endocrinology \& Metabolism; 2010. 21(6): 369-374. 
Meghji S, Morrison MS, Henderson B, Arnett TR. pH dependence of bone resorption: mouse calvarial osteoclasts are activated by acidosis. Am J Physiol Endocrinol Metab 2001;280(1):E112-9.

Mizunashi K, Furukawa Y, Katano K, Abe K. Effect of omeprazole, an inhibitor of $\mathrm{H}^{+} / \mathrm{K}^{+}$-ATPase, on bone resorption in humans. Calcif Tissue Int 1993;53:21-5.

Mori M, Sakai H, Morihata H, Kawawaki J, Amano H, Yamano T, Kuno M. Regulatory Mechanisms and Physiological Relevance of a Voltage-Gated $\mathrm{H}^{+}$Channel in Murine Osteoclasts: Phorbol Myristate Acetate Induces Cell Acidosis and the Channel Activation. J Bone Mineral Res 2003; 18(11): 2069-2076.

Noble BS, Peet N, Stevens HY, Brabbs A, Mosley JR, Reilly GC, Reeve J, Skerry TM, Lanyon LE. Mechanical loading: biphasic osteocyte survival and targeting of osteoclasts for bone destruction in rat cortical bone. Am J Physiol Cell Physiol 2003 Apr;284(4):C934-43.

Nordström T, Shrode LD, Rotstein OD, Romanek R, Goto T, Heersche JN, Manolson MF, Brisseau GF, Grinstein S. Chronic extracellular acidosis induces plasmalemmal vacuolar type $\mathrm{H}^{+}$ATPase activity in osteoclasts. J Biol Chem 1997;272(10):6354-60.

Nordström T, Rotstein OD, Romanek R, Asotra S, Heersche JNM, Manolson MF, Brisseau GF, Grinstein S. Regulation of cytoplasmic $\mathrm{pH}$ in osteoclasts. Contribution of proton pumps and a proton-selective conductance. $\mathrm{J}$ Biol Chem 1995;270(5):2203-12.

Okamoto F, Kajiya H, Toh K, Uchida S, Yoshikawa M, Sasaki S, Kido MA, Tanaka T, Okabe K. Intracellular ClC-3 chloride channels promote bone resorption in vitro through organelle acidification in mouse osteoclasts. Am J Physiol Cell Physiol. 2008 Mar;294(3):C693-701. Epub 2008 Jan 30.

Pasquale SM et al. J Appl Physiol1980:48:197-201.

Ramsey S, Moran1 MM, Chong1 JA, Clapham DE. voltage-gated proton-selective channel lacking the pore domain. Nature 2006; 440(27):1213-1216.

Ravesloot JH, Eisen T, Baron R, Boron WF. Role of $\mathrm{Na}^{+} / \mathrm{H}^{+}$exchangers and vacuolar $\mathrm{H}^{+}$-pumps in intracellular $\mathrm{pH}$ regulation in neonatal rat osteoclasts. J Gen Physiol 1995;105(2):177-208.

Robey AG, Boske AL. The composition of bone. In: Primer on the Metabolic Bone Diseases and Disorders of Mineral Metabolism. American Society for Bone and Mineral Research. 2008; p. 32-38.

Roodman GD. Biology of osteoclast activation in cancer. J Clin Oncol. 2001 Aug 1;19(15):3562-71. Review.

Rousselle AV, Heymann D. Osteoclastic acidification pathways during bone resorption. Bone 2002;30(4):53340. Review.

Sahara T, Itoh K, Debari K, Sasaki T. Specific biological functions of vacuolar-type $\mathrm{H}^{+}$-ATPase and lysosomal cysteine proteinase, cathepsin K, in osteoclasts. Anat Rec 2003;270A(2):152-61.

Sakai H, Kawawaki J, Moriura Y, Mori H, Morihata H, Kuno M. pH dependence and inhibition by extracellular calcium of proton currents via plasmalemmal vacuolar-type $\mathrm{H}^{+}$-ATPase in murine osteoclasts. J Physiol 2006;576(Pt 2):417-25.

Salo J, Lehenkari P, Mulari M, Metsikko K, Vaananen HK. Removal of osteoclast bone resorption products by transcytosis. Science 1997;276:270-3.

Salter DM, Robb JE, Wright MO. Electrophysiological responses of human bone cells to mechanical stimulation: evidence for specific integrin function in mechanotransduction. J Bone Miner Res 1997 Jul;12(7):1133-41.

Schlesinger PH, Blair HC, Teitelbaum SL, Edwards JC. Characterization of the Osteoclast Ruffled Border Chloride Channel and Its Role in Bone Resorption. J Biol Chem 1997; Vol. 272, No. 30, Issue of July 25, pp. 18636-18643. 
Shibata T, Amano H, Yamada S, Ohya K. Mechanisms of proton transport in isolated rat osteoclasts attached to bone. J Med Dent Sci 2000;47(3):177-85.

Silver IA, Murrilis RJ, Etherington DJ. Microeletrode studies on the acid microenvironment beneath adherent macrophages and osteoclasts. Exp Cell Res 1988;175(2):266-76.

Tan SD, de Vries TJ, Kuijpers-Jagtman AM, Semeins CM, Everts V, Klein-Nulend J. Osteocytes subjected to fluid flow inhibit osteoclast formation and bone resorption. Bone. 2007 Nov;41(5):745-51. Epub 2007 Aug 10.

Teitelbaum SL. Bone resorption by osteoclasts. Science 2000;289:1504-8.

Teti A, Blair HC, Teitelbaum SL, Kahn AJ, Koziol C, Konsek J, Zambonin-Zallone A, Schlesinger PH. Cytoplasmic $\mathrm{pH}$ regulation and chloride/bicarbonate exchange in avian osteoclasts. J Clin Invest 1989; 83(1): 227-33.

Teti A, Blair HC, Schlesinger P, Grano M, Zambonin-Zallone A, Kahn AJ, Teitelbaum SL, Hruska KA. Extracellular protons acidify osteoclasts, reduce cytosolic calcium, and promote expression of cell-matrix attachment structures. J Clin Invest 1989;84(3):773-80.

Teti A, Marchisio PC, Zallone AZ. Clear zone in osteoclast function: role of podosomes in regulation of boneresorbing activity. Am J Physiol 1991;261:C1-C7.

Tondravi MM, McKercher SR, Anderson K, Erdmann JM, Quiroz M, Maki R, Teitelbaum SL. Osteopetrosis in mice lacking haematopoietic transcription factor PU.1. Nature 1997;386(6620):81-4.

Yao G, Feng H, Cai Y, Qi W, Kong K. Characterization of vacuolar-ATPase and selective inhibition of vacuolar-H+-ATPase in osteoclasts. Biochem Biophys Res Commun 2007;357(4):821-7.

Vaananen HK, Karhukorpi EK, Sundquist K, Wallmark B, Roininen I, Hentunen T, Tuukkanen J, Lakkakorpi P. Evidence for the presence of a proton pump of the vacuolar H+-ATPase type in the ruffled borders of osteoclasts. J Cell Biol 1990;111(3):1305-11.

Zaidi M, Blair HC, Moonga BS, Abe E, Huang CL. Osteoclastogenesis, bone resorption, and osteoclast-based therapeutics. J Bone Miner Res 2003;18(4):599-609.

Zhao H, Rhoss FP. Mechanisms of Osteoclasts Secretion. Ann NY Acad Sci 2007;1116: 238-244.

Zimolo Z, Wesolowski G, Rodan GA. Acid extrusion is induced by osteoclast attachment to bone. Inhibition by alendronate and calcitonin. J Clin Inv 1995;96: 2277-2283. 